\title{
Ambient Quality of Ground Water in the Vicinity of Naval Submarine Base Bangor, Kitsap County, Washington, 1995
}

By Karen E. Greene

U.S. Geological Survey

Water-Resources Investigations Report 96-4309

Prepared in cooperation with

DEPARTMENT OF THE NAVY

ENGINEERING FIELD ACTIVITY, NORTHWEST

NAVAL FACILITIES ENGINEERING COMMAND 


\title{
U.S. DEPARTMENT OF THE INTERIOR
}

BRUCE BABBITT, Secretary

\author{
U.S. GEOLOGICAL SURVEY
}

Gordon P. Eaton, Director

Any use of trade, product, or firm names is for descriptive purposes only and does not imply endorsement by the U.S. Government.

For additional information write to:

District Chief

U.S. Geological Survey

1201 Pacific Avenue - Suite 600

Tacoma, Washington 98402
Copies of this report may be purchased from:

U.S. Geological Survey

Branch of Information Services

Box 25286, MS 517

Denver, Colorado 80225-0286 


\section{CONTENTS}

Abstract-----

Introduction ---

Purpose and scope - -

Acknowledgments --

Description of the study area -...-...- 2

Previous water-quality investigations -

Hydrogeology -

Approach and methods --

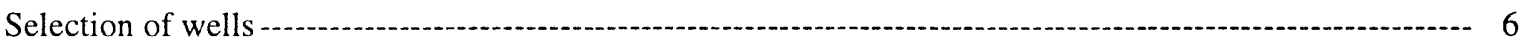

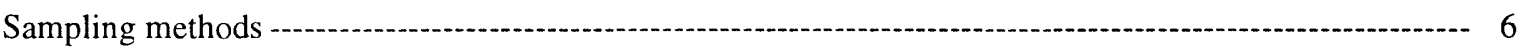

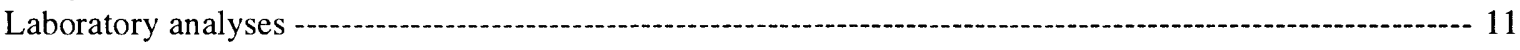

Quality assurance and control samples - - 11

Methods used to interpret water-quality data ---

Drinking water standards - 13

Determination of ambient background levels -

Tools used to describe ambient water quality -

Water quality in the vicinity of SUBASE Bangor -

Characterization of ambient water quality - 16

Detections of organic compounds --.-- 37

Ambient background levels of inorganic constituents - 37

Summary and conclusions - -

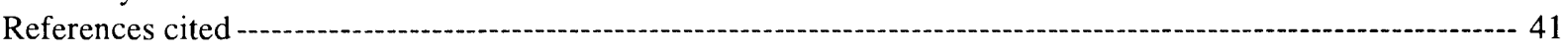

Appendix A.--Summary of existing water-quality data for the Deep aquifer--o-n 43

Appendix B.--Wells sampled for ambient water quality March and April 1995 ---

Appendix C.--Example Piper diagram showing water type represented in each area -..-- 46

\section{FIGURES}

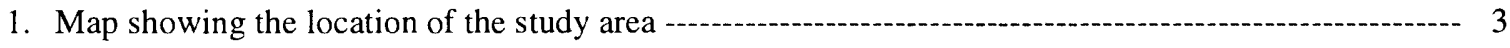

2. Generalized diagram showing a simplified conceptual model of the hydrogeology in the

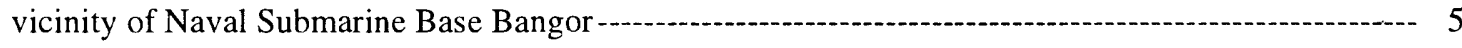

3. Map showing locations of wells sampled for ambient water quality March and April 1995 .....-...-.-- 7

4. Piper diagrams for all major-ion samples collected in the study area and in each hydrogeologic unit

5. Maps showing wells with high measured $\mathrm{pH}$, low measured dissolved oxygen, iron concentration exceeding the SMCL of $300 \mu \mathrm{g} / \mathrm{L}$, and manganese concentration exceeding the SMCL of $50 \mu \mathrm{g} / \mathrm{L}---{ }^{2}$

6. Boxplots of 40 constituents, grouped by hydrogeologic unit-a- 24

7. Graphs showing relationships between concentrations of dissolved oxygen, dissolved organic carbon, iron, and manganese

8-9. Maps showing wells sampled for:

8. Trace elements, and wells with concentrations of $20 \mu \mathrm{g} / \mathrm{L}$ or more aluminum, $5 \mu \mathrm{g} / \mathrm{L}$ or more arsenic, or $10 \mu \mathrm{g} / \mathrm{L}$ or more chromium

9. Organic compounds, and locations of wells with detected concentrations of organic compounds 


\section{TABLES}

1. Constituents measured in filtered water samples collected from all wells-

2. Trace elements measured in filtered water samples collected from 82 wells $-\cdots$

3. Organic compounds measured in unfiltered water samples from 50 wells

4. Organic compounds measured in unfiltered water samples from 33 wells --..-- 10

5. Inorganic constituents detected in quality assurance and control field blank samples - -

6. Drinking water standards for inorganic constituents - 13

7. Median (50th percentile) concentrations of selected inorganic constituents -- 39

8. Ninetieth percentile concentrations of selected inorganic constituents - 40

\section{CONVERSION FACTORS AND VERTICAL DATUM}

\begin{tabular}{|c|c|c|}
\hline Multiply & By & To obtain \\
\hline $\begin{array}{r}\text { inch (in) } \\
\text { foot }(\mathrm{ft}) \\
\text { mile }(\mathrm{mi}) \\
\text { acre } \\
\\
\text { square mile }\left(\mathrm{mi}^{2}\right) \\
\text { gallon }(\mathrm{gal}) \\
\text { pound }(\mathrm{lb})\end{array}$ & $\begin{array}{c}25.4 \\
0.3048 \\
1.609 \\
4,047 \\
0.4047 \\
2.590 \\
3.785 \\
453.6\end{array}$ & $\begin{array}{l}\text { millimeter } \\
\text { meter } \\
\text { kilometer } \\
\text { square meter } \\
\text { hectare } \\
\text { square kilometer } \\
\text { liter } \\
\text { grams }\end{array}$ \\
\hline \multicolumn{3}{|c|}{$\begin{array}{l}\text { Temperature: To convert temperature given in this report in degrees Fahrenheit }\left({ }^{\circ} \mathrm{F}\right) \text { to degrees Celsius }\left({ }^{\circ} \mathrm{C}\right) \text {, use the } \\
\text { following equation: }{ }^{\circ} \mathrm{C}=5 / 9\left({ }^{\circ} \mathrm{F}-32\right) \text {. } \\
\text { Sea Level: In this report "sea level" refers to the National Geodetic Vertical Datum of } 1929 \text { (NGVD of 1929)--a } \\
\text { geodetic datum derived from a general adjustment of the first-order level nets of both the United States and Canada, } \\
\text { formerly called Sea Level Datum of } 1929 \text {. }\end{array}$} \\
\hline
\end{tabular}




\title{
AMBIENT QUALITY OF GROUND WATER IN THE VICINITY OF NAVAL SUBMARINE BASE BANGOR, KITSAP COUNTY, WASHINGTON, 1995
}

\author{
By Karen E. Greene
}

\begin{abstract}
A study of the ambient ground-water quality in the vicinity of Naval Submarine Base (SUBASE) Bangor was conducted to provide the U.S. Navy with background levels of selected constituents. The Navy needs this information to plan and manage cleanup activities on the base. During March and April 1995, 136 water-supply wells were sampled for common ions, trace elements, and organic compounds; not all wells were sampled for all constituents. Man-made organic compounds were detected in only two of fifty wells, and the sources of these organic compounds were attributed to activities in the immediate vicinities of these off-base wells. Drinking water standards for trichloroethylene, iron, and manganese were exceeded in one of these wells, which was probably contaminated by an old local (off-base) dump.
\end{abstract}

Ground water from wells open to the following hydrogeologic units (in order from shallow to deep) was investigated: the Vashon till confining unit (Qvt, three wells); the Vashon aquifer (Qva, 54 wells); the Upper confining unit (QC1, 16 wells); the Permeable interbeds within QC1 (QClpi, 34 wells); and the Sea-level aquifer (QA 1, 29 wells). The 50th and 90th percentile ambient background levels of 35 inorganic constituents were determined for each hydrogeologic unit. At least ten measurements were required for a constituent in each hydrogeologic unit for determination of ambient background levels, and data for three wells determined to be affected by localized activities were excluded from these analyses.

The only drinking water standards exceeded by ambient background levels were secondary maximum contaminant levels for iron (300 micrograms per liter), in QC1 and QC1pi, and manganese (50 micrograms per liter), in all of the units. The 90th percentile values for arsenic in QC1pi, QA1, and for the entire study area are above 5 micrograms per liter, the Model Toxics Control Act Method A value for protecting drinking water, but well below the maximum contaminant level of 50 micrograms per liter for arsenic.

The manganese standard was exceeded in 38 wells and the standard for iron was exceeded in 12 wells. Most of these wells were in QCl or QClpi and had dissolved oxygen concentrations of less than 1 milligram per liter and dissolved organic carbon concentrations greater than 1 milligram per liter. The dissolved oxygen concentration is generally lower in the deeper units, while $\mathrm{pH}$ increases; the recommended $\mathrm{pH}$ range of 6.5-8.5 standard units was exceeded in 9 wells. The common-ion chemistry was similar for all of the units.

\section{INTRODUCTION}

Naval Submarine Base (SUBASE) Bangor has been an active military installation since 1944. As a result of past activities at the facility, numerous contaminated sitcs have been identified, and the base has been placed on the U.S. Environmental Protection Agency's National Priority List. Contaminants found at the base include many metals and organic compounds. The ambient chemistry of ground water in the vicinity of the base has not yet been characterized; instead, the studies conducted at the base under the Installation Restoration Program have necessarily focused on assessing small-scale, site-specific groundwater conditions. The base needs additional information about the ground-water system to effectively plan and manage cleanup activities and overall use of the ground-water resource. 
In cooperation with the U.S. Navy, the U.S. Geological Survey began an investigation of the hydrology and water quality in the vicinity of SUBASE Bangor in 1993. This report is one of four to be published as part of the investigation. The other reports discuss the hydrogeology of the study area (Kahle, in press), the ages of ground water, and the shallow-aquifer recharge and simulated characteristics of the present ground-water flow system and possible future flow system.

\section{Purpose and Scope}

The purposes of this report are (1) to describe the ambient chemistry of ground water in the vicinity of SUBASE Bangor, including spatial and depth variations; (2) to identify water-supply wells in the study area that do not meet applicable drinking water standards; and (3) to determine the 50th and 90th percentile ambient background levels of trace elements and inorganic and organic compounds present in the ground water. The constituents analyzed are listed in the Approach and Methods section; no samples were analyzed for pesticides or radioactive materials. Existing water-supply wells, each open to only one hydrogeologic unit, provided all of the sampling points. The sampled wells had depths ranging from 43 to 538 feet.

\section{Acknowledgments}

The author thanks the many private citizens who gave permission to the U.S. Geological Survey to sample their water-supply wells and the managers of public water-supply systems who provided water-chemistry data. The author also acknowledges the following U.S. Geological Survey employees for their work during this investigation: Gary Holloway, Karen Payne, Greg Justin, and Steve Cox helped collect data; Jim Ebbert provided technical assistance; Raegan Sramek helped verify data; Connie Dean helped with laboratory records; and Tina Samaduroff compiled geographic information system (GIS) data and produced the maps in this report.

\section{DESCRIPTION OF THE STUDY AREA}

Naval Submarine Base Bangor is a 6,785-acre (10.6 square mile) installation located on the Kitsap peninsula along Hood Canal in northwest Kitsap County,
Wash. (fig. 1). The study area includes the base and about 80 square miles of surrounding land. SUBASE Bangor is currently one of two bases that support the U.S. Navy's Trident nuclear missile system and has been the home port for eight Trident missile submarines since 1974. Facilities for training, repair, weapons handling, military housing, and administrative activities are located on the base. The facility employs more than 10,000 military and civilian personnel and had 2,830 residents in 1993 (Parametrix, Inc., 1994). Most of the off-base population is concentrated in two towns: in 1990, there were 7,660 people residing in Silverdale and 4,848 in Poulsbo (U.S. Bureau of the Census, 1992). Outside of these towns, many homes have private wells for their water supplies. The base also relies on ground water for all of its water-supply needs. About 47 percent of the study area is covered by mixed coniferous and deciduous forest, and about 13 percent is urban and military development; the remainder of the study area is mixed agricultural land and native nonforest vegetation. There are no major surface-water drainages in the study area. Kitsap County has a temperate marine climate: the average annual precipitation and temperature are about 50 inches and $51^{\circ} \mathrm{F}$ (Hansen and Bolke, 1980).

Naval activities at SUBASE Bangor began in 1944 when a naval magazine facility was established. The base was redesignated an ammunition depot in 1947, where ordnance was received, stored, and shipped intermittently until 1973. Expendable ordnance also was dismantled at the base; this involved removing and incinerating the ordnance chemicals and washing residual chemicals from the empty ordnance casings. In 1962, SUBASE Bangor was designated a Polaris Missile Facility; a battery shop, pure water facility, and nuclear missile support facilities were constructed. In 1974 these facilities were redesignated the Strategic Weapons Facility Pacific and expanded to include support of the Trident missile system; new piers, an off-shore dry-dock, and other support facilities were constructed.

As a result of past activities at the facility, there are many sites on the base with contaminated soil and shallow ground water; remedial activities are underway at many of these sites. The sites include fuel oil and other spills, waste pits, landfills, buried drums, incineration areas, and vehicle maintenance facilities, and comprise about 10 percent of the land area of the base. Contaminants include ordnance chemicals, metals, chlorinated hydrocarbons, petroleum hydrocarbons, pesticides, and polychlorinated biphenyls (PCBs). 


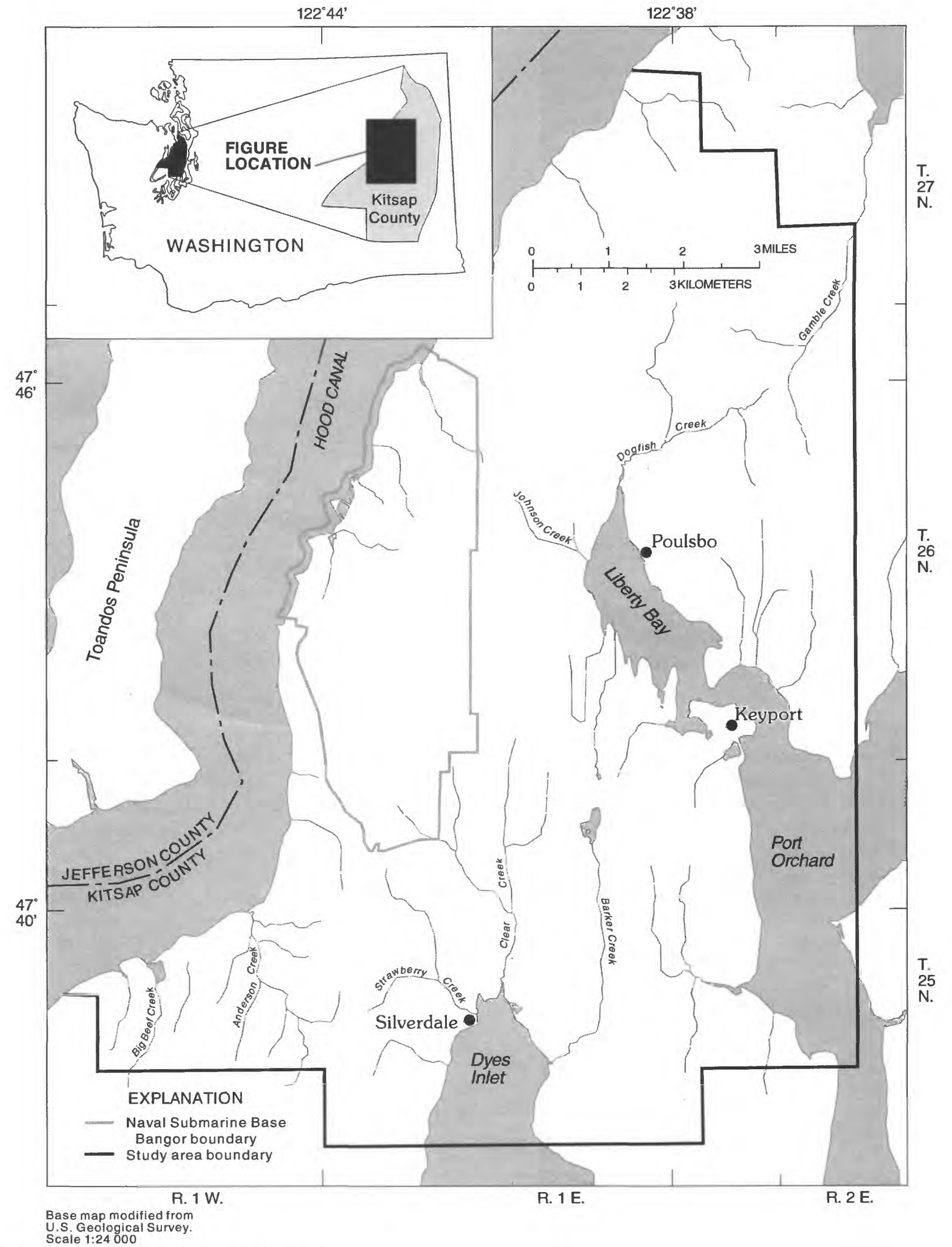

Figure 1. Location of the study area. 


\section{Previous Water-Quality Investigations}

Many studies related to cleanup activities have been conducted around the base. These studies have focused on characterizing shallow ground-water and soil contamination at individual sites. The background water-quality data collected for these studies are from nearby locations that may have been influenced by other activities on the base; these studies express a general need for additional off-site water-quality data (Hart-Crowser, Inc., 1988 and 1989).

Historical (1978-88) water-quality data for more than 550 wells throughout the Kitsap County were summarized in the Ground Water Management Plan, or Kitsap GWMP (Kitsap County Ground Water Advisory Committee and others, 1991). For the part of the county that includes most of the study area from Poulsbo south, concentrations of chloride, fluoride, iron, manganese, nitrate, sodium, sulfate, arsenic, barium, cadmium, chromium, lead, selenium, silver, and zinc in shallow wells (less than 100 feet deep) were compared with concentrations in deep wells (more than 100 feet deep). Concentrations of iron and manganese exceeding secondary standards for drinking water were common. Concentrations of constituents reported in the Kitsap GWMP showed similar differences between "shallow" and "deep" ground water and, overall, generally were within the observed range of concentrations measured during this investigation.

Additional water-quality data were obtained from compliance monitoring samples collected by large public-supply wells, several of which are located on the base. Many of these wells are open to multiple hydrogeologic units, and many of the samples were collected either at the point of distribution or just after the point of chemical treatment of the water; therefore, the data are not suitable for characterizing ambient water quality. Some previously collected data for chloride concentrations in wells open to the Deep aquifer (QA2, described in the following section) are presented in Appendix A; these data include samples of untreated water collected from public-supply wells owned by the city of Silverdale (fig. 1). (No samples were collected from wells open to the Deep aquifer during this study.) A study of coastal seawater intrusion in 1978 found that the median concentration of chloride in wells located along the Kitsap County coastline was 3.3 milligrams per liter (mg/L) (Dion and Sumioka, 1984).

\section{Hydrogeology}

The study area is located on glacial terrain with steep near-shore topography and moderate inland slopes. Alternating layers of unconsolidated sands and gravels, till, and clays are exposed in cliffs along the shorelines. A shallow aquifer is in advance outwash deposits of the Vashon glaciation, which occurred from 15,000 to 10,000 years ago, and two deeper aquifers are in older interglacial and glacial deposits. Bedrock is typically more than 1,000 feet below the land surface (Jones, 1996). The hydrogeology of the study area is described in detail by Kahle (in press); the hydrogeologic units identified by Kahle are shown in simplified cross-section on figure 2.

The Vashon till confining unit (Qvt) is a low-permeability unit consisting of compacted and poorly sorted sand, silt, and gravel, and includes water-bearing lenses of sand and gravel; Qvt is typically from 10 to 100 feet thick. The Vashon aquifer (Qva), commonly called the shallow aquifer in earlier reports, is an unconfined or locally confined aquifer consisting of sand and smaller amounts of gravel; Qva is typically from 20 to 200 feet thick. The Upper confining unit (QC1), commonly called the Kitsap or Whidbey Formation in earlier reports, is a low-permeability unit consisting of lacustrine silt and clay overlying cemented sand, silt, and gravel that also contains Permeable interbeds (QC1pi), commonly called intermediate zones or the semi-perched aquifer in earlier reports, where sand and gravel zones are locally continuous; QC1 is typically from 100 to 300 feet thick and QC1pi typically ranges from 10 to 50 feet in thickness. The Sea-level aquifer (QA1), commonly called the Sea-level aquifer or the Salmon Springs Drift in earlier reports, is a confined aquifer consisting of non-glacial sand and gravel; QA1 is typically from 40 to 140 feet thick. The Lower confining unit (QC2) is a discontinuous low-permeability unit consisting of silty sandy clay; where present, QC2 is typically from 80 to 160 feet thick. The Deep aquifer (QA2) is a confined aquifer consisting of sand and gravel that is locally in direct hydraulic connection with QA1 where QC2 is absent; QA2 is typically from 100 to 160 feet thick. The Basal confining unit (QC3) is a low-permeability unit consisting of blue clay and silt that is typically more than 100 feet thick. The Undifferentiated deposits (QU) below QC3 are unconsolidated deposits that are approximately 100 to 700 feet thick. 
Although Qvt and QC1 are regionally considered to be confining units, these two hydrogeologic units are productive enough for small domestic water supply wells, and many wells open to Qvt and QC1 were included in this investigation. However, most of the wells included in this study are open to Qva, QClpi, and QA1. Wells open to the deeper aquifers generally are large public supply wells, many of which are open to multiple hydrogeologic units and therefore were not included in the study. Results from previous sampling of five wells that are open only to QA2 are presented in Appendix A.

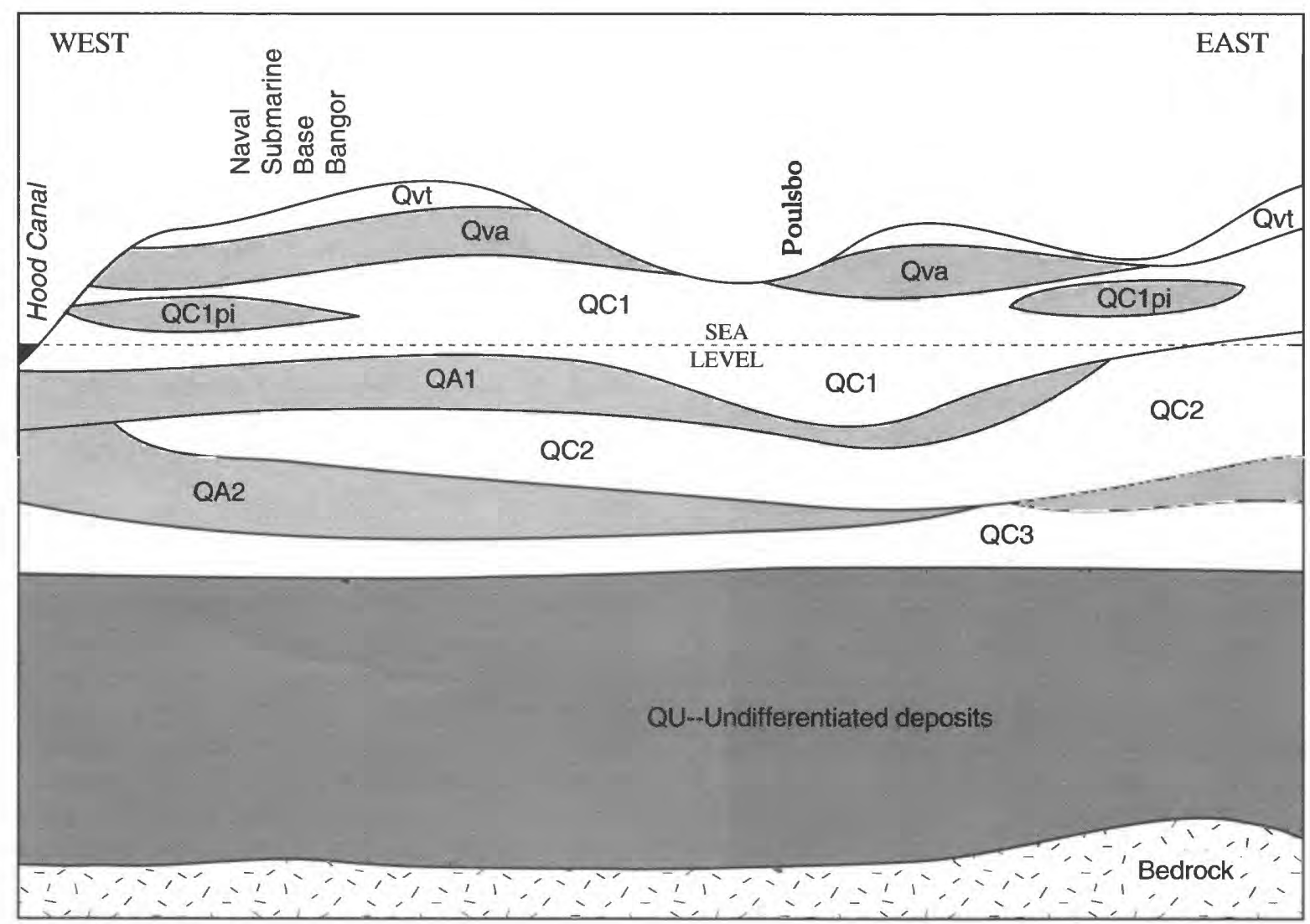

NOT TO SCALE

\section{EXPLANATION}

$\begin{array}{ll}\square \quad \text { Less permeable units } \\ \square \quad \text { Permeable units } \\ \square \quad \text { QU--Undifferentiated deposits } \\ \square-\text { Bedrock } \\ \text { Qva } & \text { Vashon till confining unit } \\ & \text { Vashon aquifer }\end{array}$

$\begin{array}{ll}\text { QC1 } & \text { Upper confining unit } \\ \text { QC1pi } & \text { Permeable interbeds } \\ \text { QA1 } & \text { Sea-level aquifer } \\ \text { QC2 } & \text { Lower confining unit } \\ \text { QA2 } & \text { Deep aquifer } \\ \text { QC3 } & \text { Basal confining unit }\end{array}$

Figure 2. Simplified conceptual model of the hydrogeology in the vicinity of Naval Submarine Base Bangor (after Kahle, in press). Permeable units include sand and gravel outwash and alluvium; less permeable units include till, silt, clay, and cemented silt, sand, and gravel. 


\section{APPROACH AND METHODS}

During March and April 1995, the U.S. Geological Survey sampled 136 water-supply wells to determine ambient levels of trace elements and to identify any presence of man-made organic contaminants in ground water in the vicinity of Naval Submarine Base Bangor. Measured concentrations of the constituents were compared to applicable drinking water standards and were analyzed to identify spatial variations and variations among hydrogeologic units.

\section{Selection of Wells}

The sampled wells were selected from among 489 wells inventoried for the project as described by Kahle (in press); wells located far to the south of Poulsbo, east of Liberty Bay, were excluded from this investigation. All of these wells were visited at least once prior to sampling: the inventory process included confirmation of the location and land-surface elevation of the well; evaluation of the well driller's log; description of the plumbing of the well, including the existence and placement of holding tanks and any physical or chemical water treatment system; and identification of obvious possible local sources of contamination, such as gasoline, fertilizers, or pesticides stored near the well head or nearby waste-disposal areas. Because ambient water quality was of interest, sampling of wells with known local contamination was avoided.

Because the aquifer or confining unit to which each well is open was not known at the time of sampling, wells were selected to provide as broad a distribution of depths below land surface as possible. Figure 3 shows the locations of the wells selected for sampling and the hydrogeologic unit to which each well is open. The hydrogeologic unit assignments were determined by Kahle (in press), whose findings (together with the results from this study) may be useful in selecting wells for future sampling efforts. Most of the 136 wells sampled for water quality were located less than about 2 miles from the boundary of the base (seven wells on the base were sampled); additional wells were located throughout the study area.

In Washington, wells are assigned numbers that identify their location within a township, range, section, and 40 -acre tract. For example, the well number $25 \mathrm{~N} /$ 01E-03K01 indicates that the well is in township 25 North $(25 \mathrm{~N})$ of the Willamette base line, which is located in northern Oregon, and in range 1 East (01E) of the Willamette meridian, which runs through the study area as shown on figure 3 . The number immediately following the hyphen indicates the section (03) within the township and the letter indicates the 40-acre tract (K). The last two numbers indicate the order in which the well was inventoried by USGS personnel (see Kahle, in press). If the local well number is followed by D1, this means that the well was deepened once. On figure 3 , the wells are identified only by the section and 40 -acre tract (" $03 \mathrm{~K}$ " for $25 \mathrm{~N}$ / 01E-03K01), and the USGS sequence number is given only when multiple wells in the same tract were sampled for this study. The depths and complete local identification numbers of the wells are listed in Appendix B.

The criteria for selection of a well for sampling were the following: (1) the length of the well casing open to the aquifer, or the screened interval, was less than 20 feet except in two wells located on the base that have larger screened intervals (seven of the wells are not screened at all and instead draw water from an open hole); (2) the plumbing of the well was such that it was possible to sample the well water before any water-treatment device, and it also was possible to sample for man-made organic compounds before any holding tank; and (3) permission to sample the well was given by the resident or well owner.

\section{Sampling Methods}

Samples from all wells were analyzed to determine concentrations of nutrients, common ions, iron, manganese, and dissolved organic carbon (table 1); no additional constituents were measured in water samples from 54 of the 136 wells. Concentrations of 20 trace elements (table 2) were measured in samples collected from 82 wells. In samples from 50 of these 82 wells, concentrations of 61 volatile organic compounds (VOCs) also were measured (table 3); and for 33 of these 50 samples, concentrations of 48 semi-volatile organic compounds and 19 ordnance (explosive) compounds were measured (table 4) in addition to the VOCs. The groups of constituents sampled at each well are listed in Appendix B. Dissolved oxygen, $\mathrm{pH}$, specific conductance, water temperature, and carbonate alkalinity were measured for all wells in the field at the time of sampling. Concentrations are reported in units of $\mathrm{mg} / \mathrm{L}$, or parts per million, or in micrograms per liter $(\mu \mathrm{g} / \mathrm{L}$ ), or parts per billion. (All data collected during this study can be obtained in ASCII format on a floppy disk by calling the U.S. Geological Survey Washington District office in Tacoma, Wash., at (253) 593-6510, and are available on the World Wide Web. Please check the Washington District Homepage at:

http://wwwdwatcm.wr.usgs.gov/project_data/bangor/ Note that "wwwdwatcm" does not have a dot symbol.) 


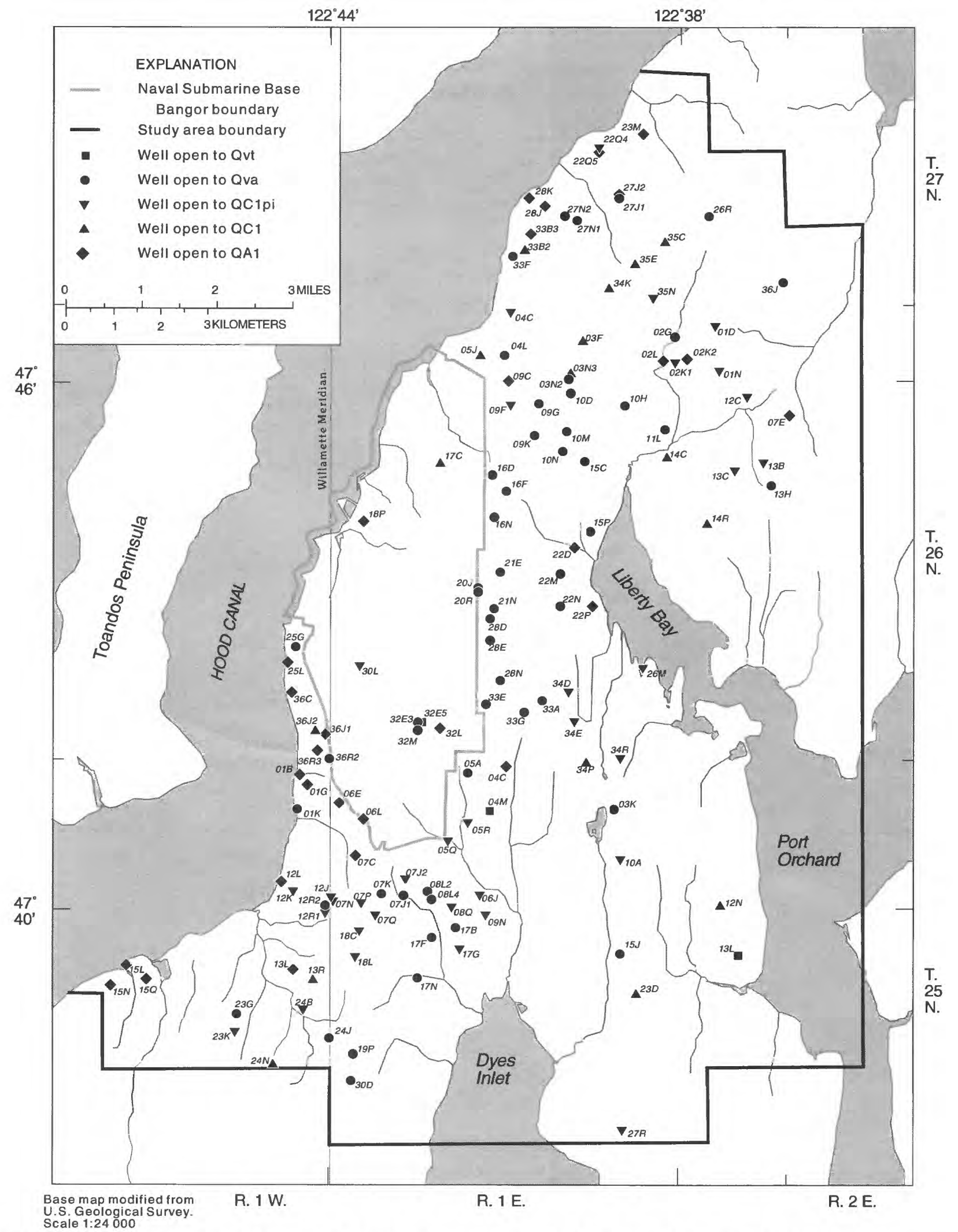

Figure 3. Location of wells sampled for ambient water quality, March and April 1995. The wells are listed in Appendix B. USGS sequence numnbers are shown only where more than one well in a tract were sampled. See page 6 for explanation of the well numbering system. 
Table 1.--Constituents measured in filtered water samples collected from all wells

[mg/L, milligrams per liter. The filter size was $0.1 \mu \mathrm{m}$ (micrometer, or micron) for all constituents except organic carbon. Ammonia, nitrate, and nitrite are reported as nitrogen, and orthophosphate is reported as phosphorus]

\begin{tabular}{lclc}
\hline Constituent & $\begin{array}{l}\text { Reporting } \\
\text { level }(\mathrm{mg} / \mathrm{L})\end{array}$ & Constituent & $\begin{array}{c}\text { Reporting } \\
\text { level }(\mathrm{mg} / \mathrm{L})\end{array}$ \\
\hline Calcium & 0.02 & Iron & 0.003 \\
Magnesium & .01 & Manganese & .001 \\
Sodium & .2 & Nitrate plus nitrite & .05 \\
Potassium & .1 & Nitrite & .01 \\
Chloride & .1 & Ammonia & .015 \\
Sulfate & .1 & Ammonia plus organic nitrogen & .2 \\
Fluoride & .1 & Orthophosphate & .01 \\
Bromide & .01 & Phosphorus & .01 \\
Silica & .01 & Organic carbon $(0.45 \mu \mathrm{m}$ filter $)$ & .1 \\
\hline
\end{tabular}

Table 2.--Trace elements measured in filtered water samples collected from 82 wells $[\mu \mathrm{g} / \mathrm{L}$, micrograms per liter. The filter size was $0.1 \mu \mathrm{m}$ (micrometer, or micron)]

\begin{tabular}{lclclc}
\hline Element & $\begin{array}{l}\text { Reporting } \\
\text { level }(\mu \mathrm{g} / \mathrm{L})\end{array}$ & Element & $\begin{array}{l}\text { Reporting } \\
\text { level }(\mu \mathrm{g} / \mathrm{L})\end{array}$ & Element & $\begin{array}{l}\text { Reporting } \\
\text { level }(\mu \mathrm{g} / \mathrm{L})\end{array}$ \\
\hline Aluminum & 10 & Cobalt & 3 & Nickel & 10 \\
Arsenic & 1 & Copper & 10 & Selenium & 1 \\
Barium & 2 & Iodide & 1 & Silver & 1 \\
Beryllium & 0.5 & Lead & 1 & Strontium & 0.5 \\
Boron & 10 & Lithium & 4 & Vanadium & 6 \\
Cadmium & 1 & Mercury & 0.1 & Zinc & 3 \\
Chromium & 5 & Molybdenum & 10 & & \\
\hline
\end{tabular}


Table 3.-- Organic compounds measured in unfiltered water samples from 50 wells

$[\mu \mathrm{g} / \mathrm{L}$, micrograms per liter; MCL, maximum contaminant level; --, no MCL has been established for the compound. MCLs are listed in U.S. Environmental Protection Agency, 1994a and 1994b.]

\begin{tabular}{|c|c|c|c|c|c|}
\hline $\begin{array}{l}\text { Volatile } \\
\text { compound name }\end{array}$ & $\begin{array}{l}\text { Reporting } \\
\text { level }(\mu \mathrm{g} / \mathrm{L})\end{array}$ & $\begin{array}{l}\text { MCL } \\
(\mu \mathrm{g} / \mathrm{L})\end{array}$ & $\begin{array}{l}\text { Volatile } \\
\text { compound name }\end{array}$ & $\begin{array}{l}\text { Reporting } \\
\text { level }(\mu \mathrm{g} / \mathrm{L})\end{array}$ & $\begin{array}{l}\mathrm{MCL} \\
(\mu \mathrm{g} / \mathrm{L})\end{array}$ \\
\hline Benzene & 0.2 & 5 & cis-1,3-Dichloropropene & 0.2 & -- \\
\hline Bromobenzene & 0.2 & -- & trans-1,3-Dichloropropene & 0.2 & -- \\
\hline Bromochloromethane & 0.2 & -- & Ethylbenzene & 0.2 & 700 \\
\hline Bromoform & 0.2 & 100 & Ethylene dibromide & 0.2 & 0.05 \\
\hline$n$-Butylbenzene & 0.2 & -- & Hexachlorobutadiene & 0.2 & -- \\
\hline sec-Butylbenzene & 0.2 & -- & Isopropylbenzene & 0.2 & -- \\
\hline tert-Butylbenzene & 0.2 & -- & 4-Isopropyltoluene & 0.2 & -- \\
\hline Carbon tetrachloride & 0.2 & 5 & Methyl bromide & 0.2 & -- \\
\hline Chlorobenzene & 0.2 & 100 & Methyl chloride & 0.2 & -- \\
\hline Chloroethane & 0.2 & -- & Methylene chloride & 0.2 & 5 \\
\hline 2-Chloroethyl vinyl ether & 1.0 & -- & Methyl tert-butyl ether & 0.2 & -- \\
\hline Chloroform & 0.2 & 100 & Napthalene & 0.2 & -- \\
\hline 2-Chlorotoluene & 0.2 & -- & $n$-Propylbenzene & 0.2 & -- \\
\hline 4-Chlorotoluene & 0.2 & -- & Styrene & 0.2 & 100 \\
\hline Dibromochloromethane & 0.2 & 100 & $1,1,1,2$-Tetrachloroethane & 0.2 & -- \\
\hline Dibromochloropropane & 1.0 & 0.2 & 1,1,2,2-Tetrachloroethane & 0.2 & -- \\
\hline Dibromomethane & 0.2 & -- & Tetrachloroethylene & 0.2 & 5 \\
\hline 1,2-Dichlorobenzene & 0.2 & 600 & Toluene & 0.2 & 1,000 \\
\hline 1,3-Dichlorobenzene & 0.2 & -- & 1,2,3-Trichlorobenzene & 0.2 & -- \\
\hline 1,4-Dichlorobenzene & 0.2 & 75 & 1,2,4-Trichlorobenzene & 0.2 & 70 \\
\hline Dichlorobromomethane & 0.2 & 100 & $1,1,1$-Trichloroethane & 0.2 & 200 \\
\hline Dichlorodifluoromethane & 0.2 & -- & 1,1,2-Trichloroethane & 0.2 & 5 \\
\hline 1,1-Dichloroethane & 0.2 & -- & Trichloroethylene & 0.2 & 5 \\
\hline 1,2-Dichloroethane & 0.2 & 5 & Trichlorofluoromethane & 0.2 & -- \\
\hline 1,1-Dichloroethylene & 0.2 & 7 & 1,2,3-Trichloropropane & 0.2 & -- \\
\hline cis-1,2-Dichloroethylene & 0.2 & 70 & 1,1,2-Trichloro- & & \\
\hline trans-1,2-Dichloroethylene & e $\quad 0.2$ & 100 & 1,2,2-trifluoroethane & 0.2 & -- \\
\hline 1,2-Dichloropropane & 0.2 & 5 & 1,2,4-Trimethylbenzene & 0.2 & -- \\
\hline 1,3-Dichloropropane & 0.2 & -- & 1,3,5-Trimethylbenzene & 0.2 & -- \\
\hline 2,2-Dichloropropane & 0.2 & -- & Vinyl chloride & 0.2 & 2 \\
\hline 1,1-Dichloropropene & 0.2 & -- & Xylenes (total) & 0.2 & 10,000 \\
\hline
\end{tabular}


Table 4.-- Organic compounds measured in unfiltered water samples from 33 wells

$[\mu \mathrm{g} / \mathrm{L}$, micrograms per liter; MCL, maximum contaminant level; --, no MCL has been established for the compound. MCLs are listed in U.S. Environmental Protection Agency, 1994a and 1994b.]

\begin{tabular}{|c|c|c|c|c|c|c|}
\hline $\begin{array}{l}\text { Semi-volatile } \\
\text { compound name }\end{array}$ & & $\begin{array}{l}\text { porting } \\
\text { el }(\mu \mathrm{g} / \mathrm{L})\end{array}$ & $\begin{array}{l}\text { MCL } \\
(\mu \mathrm{g} / \mathrm{L})\end{array}$ & $\begin{array}{l}\text { Semi-volatile } \\
\text { compound name }\end{array}$ & $\begin{array}{l}\text { Reporting } \\
\text { evel }(\mu \mathrm{g} / \mathrm{L})\end{array}$ & $\begin{array}{l}\text { MCL } \\
(\mu \mathrm{g} / \mathrm{L})\end{array}$ \\
\hline \multicolumn{2}{|l|}{ Acenaphthene } & 5 & -- & 2,4-Dimethylphenol & 5 & -- \\
\hline \multicolumn{2}{|l|}{ Acenapthylene } & 5 & -- & Dimethylphthalate & 5 & -- \\
\hline \multicolumn{2}{|l|}{ Anthracene } & 5 & -- & 4,6-Dinitro, 2-cresol & 30 & -- \\
\hline \multicolumn{2}{|l|}{ Benzidine } & 40 & -- & 2,4-Dinitrophenol & 20 & -- \\
\hline \multicolumn{2}{|l|}{$\operatorname{Benzo}(a)$ anthracene } & 10 & 0.1 & Di-n-octylphthalate & 10 & -- \\
\hline \multicolumn{2}{|l|}{$\operatorname{Benzo}(b)$ fluoranthene } & 10 & 0.2 & 1,2-Diphenylhydrazine & 5 & -- \\
\hline \multicolumn{2}{|l|}{$\operatorname{Benzo}(k)$ fluoranthene } & 10 & 0.2 & bis-2-Ethylhexylphthalate & 5 & 6 \\
\hline \multicolumn{2}{|l|}{$\operatorname{Benzo}(g, h, i)$ perylene } & 10 & -- & Fluoranthene & 5 & -- \\
\hline \multicolumn{2}{|l|}{$\operatorname{Benzo}(a)$ pyrene } & 10 & 0.2 & Fluorene & 5 & -- \\
\hline \multicolumn{2}{|c|}{ 4-Bromophenyl phenyl ether } & 5 & -- & Hexachlorobenzene & 5 & 1 \\
\hline \multicolumn{2}{|l|}{$n$-Butylbenzylphthalate } & 5 & 100 & Hexachlorocyclopentadiene & 5 & 50 \\
\hline \multicolumn{2}{|c|}{ bis-2-Chloroethoxy methane } & 5 & -- & Hexachloroethane & 5 & -- \\
\hline \multicolumn{2}{|l|}{ bis-2-Chloroethyl ether } & 5 & -- & Indeno $(1,2,3-c, d)$ pyrene & 10 & 0.4 \\
\hline \multicolumn{2}{|l|}{ bis-2-Chloroisopropyl ether } & 5 & -- & Isophorone & 5 & -- \\
\hline \multicolumn{2}{|l|}{ 4-Chloro, 3-methylphenol } & 30 & -- & 2-Nitrophenol & 5 & -- \\
\hline \multicolumn{2}{|l|}{ 2-Chloronaphthalene } & 5 & -- & 4-Nitrophenol & 30 & -- \\
\hline \multicolumn{2}{|l|}{ 2-Chlorophenol } & 5 & -- & $n$-Nitrosodimethylamine & 5 & -- \\
\hline \multicolumn{2}{|c|}{ 4-Chlorophenyl phenyl ether } & 5 & -- & $n$-Nitrosodiphenylamine & 5 & -- \\
\hline \multicolumn{2}{|l|}{ Chrysene } & 10 & 0.2 & $n$-Nitrosodi- $n$-propylamine & 5 & -- \\
\hline \multicolumn{2}{|l|}{$\operatorname{Dibenzo}(a, h)$ anthracene } & 10 & 0.3 & Pentachlorophenol & 30 & 1 \\
\hline \multicolumn{2}{|l|}{ Di-n-butyl phthalate } & 5 & -- & Phenanthrene & 5 & -- \\
\hline \multicolumn{2}{|l|}{ 3,3'-Dichlorobenzidine } & 20 & -- & Phenol & 5 & -- \\
\hline \multicolumn{2}{|l|}{ 2,4-Dichlorophenol } & 5 & -- & Pyrene & 5 & -- \\
\hline \multicolumn{2}{|l|}{ Diethylphthalate } & 5 & -- & 2,4,6-Trichlorophenol & 20 & -- \\
\hline $\begin{array}{l}\text { Ordnance (explosive) } \\
\text { compound name }\end{array}$ & \multicolumn{2}{|c|}{$\begin{array}{l}\text { Reporting } \\
\text { level }(\mu \mathrm{g} / \mathrm{L})\end{array}$} & $\begin{array}{l}\mathrm{MCL} \\
(\mu \mathrm{g} / \mathrm{L})\end{array}$ & $\begin{array}{l}\text { Ordnance (explosive) } \\
\text { compound name }\end{array}$ & $\begin{array}{l}\text { Reporting } \\
\text { level }(\mu \mathrm{g} / \mathrm{L})\end{array}$ & $\begin{array}{l}\mathrm{MCL} \\
(\mu \mathrm{g} / \mathrm{L}) \\
\end{array}$ \\
\hline 2-Amino-4,6-dinitrophen & & & & Nitroglycerin & 2.5 & -- \\
\hline (picramic acid) & & 10 & -- & 2-Nitrotoluene & 0.25 & -- \\
\hline 2-Amino-4,6-dinitrotolue & & 0.04 & -- & 3-Nitrotoluene & 0.25 & -- \\
\hline 4-Amino-2,6-dinitrotolue & & 0.06 & -- & 4-Nitrotoluene & 0.25 & -- \\
\hline 1,3-Dinitrobenzene (DNB & & 0.1 & -- & Octahydro-1,3,5,7-tetranitro & & \\
\hline 2,4-Dinitrotoluene & & 0.02 & -- & 1,3,5,7-tetrazocine (HMX & 0.8 & -- \\
\hline 2,6-Dinitrotoluene & & 0.3 & -- & Pentaerythritol tetranitrate & & \\
\hline Hexahydro-1,3,5-trinitro- & & & & $(\mathrm{PETN})$ & 10 & -- \\
\hline 1,3,5-triazine (RDX) & & 0.8 & -- & Propylene glycol dinitrate & 5 & -- \\
\hline$n$-Methyl-n-2,4,6-tetranit & & & & 1,3,5-Trinitrobenzene (TNB) & 0.3 & -- \\
\hline aniline (Tetryl) & & 0.8 & -- & 2,4,6-Trinitrophenol (picric a & acid) 10 & -- \\
\hline Nitrobenzene & & 0.25 & -- & 2,4,6-Trinitrotoluene (TNT) & 0.1 & -- \\
\hline
\end{tabular}


Wells were sampled using the existing submersible pump in use at each well. All sampling was done using the equipment and following the protocols described by Koterba and others (1995) except that the pore diameter of the filter membranes used for processing of dissolved constituent samples was 0.1 micrometer ( $\mu \mathrm{m}$ or micron) instead of $0.45 \mu \mathrm{m}$. (The pore diameter of the filters used to collect dissolved organic carbon samples was $0.45 \mu \mathrm{m}$.) If the measured dissolved oxygen concentration was less than $1.0 \mathrm{mg} / \mathrm{L}$, the measurement was confirmed using a Chemetrix rhodazine dye ampoule (White and others, 1992). The 54 wells that were sampled only for nutrients and common ions were pumped until $\mathrm{pH}$ and specific conductance readings were stable for at least ten minutes before sample collection began; the other 82 wells were pumped to produce at least three measured well volumes. Ordnance and semi-volatile organic compound samples were collected before the VOCs samples in 1 liter bottles; no preservatives were added. After sample collection at each well, equipment was decontaminated following the procedures described by Koterba and others (1995).

Because of instrument failure, dissolved oxygen was not measured in 10 wells. Because of record-keeping errors, aluminum, boron, iodide, and mercury were measured in samples from two extra wells (for a total of 84 determinations); and due to lost sample bottles, common ions were not analyzed for one well, and nutrients and dissolved organic carbon were not measured for another well.

\section{Laboratory Analyses}

Most of the water-quality analyses for this investigation, including all of the inorganic analyses, were performed by the U.S. Geological Survey National Water Quality Laboratory (NWQL) in Denver, Colo. NWQL analytical methods, listed below, are described by Fishman (1993). All inorganic analyses were performed by NWQL: concentrations of common ions and trace elements (tables 1 and 2 ) were analyzed by inductively coupled plasma (ICP), with the exception of lead (analyzed by graphite furnace atomic absorption), mercury (analyzed by cold vapor atomic absorption), bromide (analyzed by fluorescein automated-segmented flow colorimetry), and chloride and sulfate (analyzed by ion-exchange chromatography). VOCs (table 3 ) were analyzed by purge and trap gas chromatography and electron impact mass spectrometry (GC/MS), according to U.S. Environmental Protection Agency (EPA) Method 524.2 (U.S. Environmental Protection Agency, 1988); semi-volatile organic compounds (table 4 ) also were analyzed by
GC/MS at NWQL. Ordnance compounds (table 4) were analyzed by Quanterra Labs in Denver, Colo., using high-performance liquid chromatography/mass spectrometry (LC/MS), according to EPA Method 8321, after extraction by polystyrene divinylbenzene cartridge (Lindley and others, 1994); picric and picramic acids were analyzed by direct aqueous injection LC/MS.

The reporting level is the smallest measured concentration of a constituent that may be reliably reported using a given analytical method (for some organic compounds, reporting levels may occasionally be raised due to matrix interference in a sample). The reporting levels for this investigation are listed in tables 1 through 4.

\section{Quality Assurance and Control Samples}

Quality assurance and control (QA/QC) procedures were designed to quantify measurement bias and variability associated with the data collection and laboratory analysis processes. More than 10 percent of the laboratory analyses for this investigation were for QA/QC samples collected at 18 sites. QA/QC samples were collected following the procedures described by Koterba and others (1995); the types of QA/QC samples collected and processed varied among these 18 sites. Before any sampling, an equipment blank was processed to test the integrity of the sampling equipment used; beryllium, cadmium, and iodide were detected in this sample (at the respective reporting limits). A trip blank was analyzed to test handling and shipping procedures; no constituents were detected. Field blank samples, collected immediately following decontamination of sampling equipment at a well, were processed for all constituents to test decontamination procedures (the constituents detected are discussed below). Ion balances and ratios to specific conductance were calculated to check every common ions analysis as described by Friedman and Erdman (1982). Replicate samples (collected immediately following primary well-water samples), organic-spiked samples, and inorganic reference-material samples having known concentrations of constituents were analyzed to test the accuracy of laboratory determinations. Because the proper field equipment was not available at the time of sampling, quality assurance samples for organics were spiked only in the laboratory and therefore do not account for possible compound degradation during transport of the samples. Internal laboratory QA/QC checks included daily blanks, daily standards, daily instrument tuning, and quality control check samples as described by Pritt and Raese (1995). 
Field blanks were collected at 11 sites by flushing approximately two gallons of deionized water through sampling equipment after routine decontamination. This is intended to simulate the rinse by at least 50 gallons of native ground water that is achieved during the purging of a well before an environmental sample is collected; therefore, blank samples do not receive the same cleaning benefit that the rinse with copious amounts of native water provides. Inorganic constituents detected in field blank samples are listed in table 5. None of these detections were coincident with any detections in environmental samples from wells sampled before or after each blank was collected; however, the detections of cadmium, copper, silver, and zinc in field blanks at concentrations above the reporting limits make these trace-element data questionable, particularly at concentrations at or near the reporting limits; low-level iron and manganese concentrations also may be questionable. Dissolved organic carbon was detected $(0.4 \mathrm{mg} / \mathrm{L})$ in one of 11 field blank samples; the median environmental concentration was $0.3 \mathrm{mg} / \mathrm{L}$. Methylene chloride was detected in three of five field blank samples for organic constituents, with a high concentration of $0.4 \mu \mathrm{g} / \mathrm{L}$ compared to the reporting limit of $0.2 \mu \mathrm{g} / \mathrm{L}$. This compound was not detected in any environmental samples and may have been present in the organic-free water used for the field blank samples. No other organic compounds were detected in any field blank samples, and none were detected in any of the daily laboratory blanks.

Recoveries were reported for spikes of 11 of the 50 samples analyzed or VOCs. The reported concentrations of spiked constituents fell within the expected range from 60 to 140 percent of the known concentrations except for dichlorodifluoromethane, which exceeded the expected range in all but one spiked sample; bromomethane, carbon tetrachloride, chloroform, chloromethane, 2-chloroethyl vinyl ether, 1,1-dichloropropene, 2,2 dichloropropane, and 1,1,1-trichloroethane, which exceeded the expected range in one or two of the spiked samples; and acrolein and acrylonitrile, which were recovered at concentrations below the expected range in two samples.

Table 5.--Inorganic constituents detected in quality assurance and control field blank samples

[mg/L, milligrams per liter; $\mu \mathrm{g} / \mathrm{L}$, micrograms per liter; ND, not detected]

\begin{tabular}{lllll}
\hline & $\begin{array}{l}\text { Number of } \\
\text { detections } \\
\text { in field blank } \\
\text { samples }\end{array}$ & $\begin{array}{l}\text { Highest } \\
\text { concentration } \\
\text { in field blank } \\
\text { samples }\end{array}$ & $\begin{array}{l}\text { Reporting } \\
\text { limit }\end{array}$ & $\begin{array}{l}\text { Lowest } \\
\text { concentration } \\
\text { in environmental } \\
\text { samples }\end{array}$ \\
\hline Aluminum & 1 & $10 \mu \mathrm{g} / \mathrm{L}$ & $10 \mu \mathrm{g} / \mathrm{L}$ & $\mathrm{ND}$ \\
Beryllium & 1 & $0.5 \mu \mathrm{g} / \mathrm{L}$ & $0.5 \mu \mathrm{g} / \mathrm{L}$ & $\mathrm{ND}$ \\
Bromide & 3 & $0.01 \mu \mathrm{g} / \mathrm{L}$ & $0.01 \mu \mathrm{g} / \mathrm{L}$ & $\mathrm{ND}$ \\
Cadmium & 2 & $2 \mu \mathrm{g} / \mathrm{L}$ & $1 \mu \mathrm{g} / \mathrm{L}$ & $\mathrm{ND}$ \\
Calcium & 5 & $0.08 \mathrm{mg} / \mathrm{L}$ & $0.02 \mathrm{mg} / \mathrm{L}$ & $4.3 \mathrm{mg} / \mathrm{L}$ \\
Copper & 1 & $150 \mu \mathrm{g} / \mathrm{L}$ & $10 \mu \mathrm{g} / \mathrm{L}$ & $\mathrm{ND}$ \\
Iodide & 2 & $0.001 \mu \mathrm{g} / \mathrm{L}$ & $0.001 \mu \mathrm{g} / \mathrm{L}$ & $\mathrm{ND}$ \\
Iron & 4 & $16 \mu \mathrm{g} / \mathrm{L}$ & $3 \mu \mathrm{g} / \mathrm{L}$ & $\mathrm{ND}$ \\
Magnesium & 2 & $0.01 \mathrm{mg} / \mathrm{L}$ & $0.01 \mathrm{mg} / \mathrm{L}$ & $2.2 \mathrm{mg} / \mathrm{L}$ \\
Manganese & 2 & $6 \mu \mathrm{g} / \mathrm{L}$ & $1 \mu \mathrm{g} / \mathrm{L}$ & $\mathrm{ND}$ \\
Silica & 6 & $0.06 \mathrm{mg} / \mathrm{L}$ & $0.01 \mathrm{mg} / \mathrm{L}$ & $17 \mathrm{mg} / \mathrm{L}$ \\
Silver & 1 & $2 \mu \mathrm{g} / \mathrm{L}$ & $1 \mu \mathrm{g} / \mathrm{L}$ & $\mathrm{ND}$ \\
Zinc & 3 & $14 \mu \mathrm{g} / \mathrm{L}$ & $3 \mu \mathrm{g} / \mathrm{L}$ & $\mathrm{ND}$ \\
\hline
\end{tabular}




\section{Methods Used to Interpret Water-Quality Data}

The data collected for this study were used to define ambient background levels of inorganic constituents and to describe ambient ground-water quality in the study area. All data collected during the study were compared to applicable drinking water standards.

\section{Drinking Water Standards}

EPA and the Washington State Department of Health have established Primary and Secondary Maximum Contaminant Levels (MCLs and SMCLs) for many metals and organic compounds in drinking water. MCLs are set for the protection of human health; SMCLs are set to prevent aesthetic problems such as unpleasant taste, odor, or staining. The State may establish stricter standards than MCLs and SMCLs for remediation of contaminated sites (Washington State Department of Ecology, 1996). A measured concentration of any constituent above the MCL or SMCL indicates that the water is not considered suitable for use as a drinking-water supply without treatment. (Simple treatment systems, such as oxidation removal of iron and manganese, can result in decreased concentrations of many constituents of concern.) In this report, the measured concentrations are compared to the drinking water standards for each constituent that were in effect at the time of sampling; changes have been made to several Federal drinking water standards since April 1995.

Drinking water standards for organic compounds are shown in tables 3 and 4, and standards for inorganic constituents are shown in table 6. Federal MCLs and potential health effects are listed by U.S. Environmental Protection Agency (1994a); Washington State MCLs are the same (Washington State Department of Health, 1994 and 1995). Laboratory analytical methods with reporting levels below applicable drinking water standards for individual constituents were chosen when possible. (Methods with lower reporting limits were not available for two compounds listed in table 3 and nine compounds listed in table 4.)

Table 6.--Drinking water standards for inorganic constituents (U.S. Environmental Protection Agency, 1994a and 1994b; Washington State Department of Health, 1994 and 1995)

[MCL, maximum contaminant level; SMCL, secondary maximum contaminant level; $\mu \mathrm{g} / \mathrm{L}$, micrograms per liter; mg/L, milligrams per liter; --, no standard. Nitrate and nitrite are reported as nitrogen. The MCLs listed for copper and lead are action levels. Standards have not been established for constituents that were measured during the study but are not listed in the table]

\begin{tabular}{lcclcl}
\hline Constituent & MCL & SMCL & Constituent & MCL & SMCL \\
\hline Aluminum & -- & $50 \mu \mathrm{g} / \mathrm{L}$ & Lead & $15 \mu \mathrm{g} / \mathrm{L}$ & -- \\
Arsenic & $50 \mu \mathrm{g} / \mathrm{L}$ & -- & Manganese & -- & $50 \mu \mathrm{g} / \mathrm{L}$ \\
Barium & $2,000 \mu \mathrm{g} / \mathrm{L}$ & -- & Mercury & $2 \mu \mathrm{g} / \mathrm{L}$ & -- \\
Beryllium & $4 \mu \mathrm{g} / \mathrm{L}$ & -- & Nickel & $100 \mu \mathrm{g} / \mathrm{L}$ & -- \\
Cadmium & $5 \mu \mathrm{g} / \mathrm{L}$ & -- & Nitrate & $10 \mathrm{mg} / \mathrm{L}$ & -- \\
Chloride & -- & $250 \mathrm{mg} / \mathrm{L}$ & Nitrite & $1 \mathrm{mg} / \mathrm{L}$ & -- \\
Chromium & $100 \mu \mathrm{g} / \mathrm{L}$ & -- & Selenium & $50 \mu \mathrm{g} / \mathrm{L}$ & -- \\
Copper & $1,300 \mu \mathrm{g} / \mathrm{L}$ & $1,000 \mu \mathrm{g} / \mathrm{L}$ & Silver & -- & $100 \mu \mathrm{g} / \mathrm{L}$ \\
Fluoride & $4 \mathrm{mg} / \mathrm{L}$ & $2 \mathrm{mg} / \mathrm{L}$ & Sulfate & -- & $250 \mathrm{mg} / \mathrm{L}$ \\
Iron & -- & $300 \mu \mathrm{g} / \mathrm{L}$ & Zinc & -- & $5,000 \mu \mathrm{g} / \mathrm{L}$ \\
\hline
\end{tabular}




\section{Determination of Ambient Background Levels}

Ambient background levels are described in this report: true natural background conditions exist only in pristine locations untouched by human activities, and the water-supply wells sampled during this investigation may have been affected by human activities. However, a legal definition of "natural background" is given in the Model Toxics Control Act of the Washington State Administrative Code; this definition is referenced in the Washington State Department of Ecology's guidance document for site remediation managers:

\begin{abstract}
Natural background refers to the concentration of a constituent that occurs naturally in the environment and has not been influenced by localized human activities. An example ... is that several metals occur naturally in the bedrock and soils of Washington State due solely to the geologic processes that formed these materials; therefore, the concentrations of these metals would be considered natural background. In addition, some constituents have been used globally, and low concentrations of these contaminants can be found in soils and groundwater throughout much of the state. These concentrations are the result of widespread use of the constituents and not localized human activity. ... Hydrogeologic and statistical information should be considered in evaluating the representativeness of groundwater samples for defining a background value related to site conditions. It is not necessary that samples be collected from hydraulically connected locations, but it is necessary that they be from representative locations. (Washington State Department of Ecology, 1992)
\end{abstract}

Representative wells, for the purposes of this report, are wells that are open to the same hydrogeologic unit and are not known to be affected by local contamination.

Although water-supply wells may be affected by septic systems, changes in land use, or other human activities to varying degrees, they still may be considered representative of ambient background conditions. In this investigation, the criteria for deciding whether or not a given well was considered to be affected by localized human activities were (1) comparison of the basic chemistry data (common-ions concentrations and specific conductance);

(2) the presence of man-made organic compounds; and

(3) knowledge of localized activities in the vicinity of the wells. If a well had unusual chemistry for the study area, then more site-specific information about the well was considered. The following wells had unusual common-ion chemistry and also had elevated concentrations of several common ions (see fig. 3 for locations of the wells).

\begin{tabular}{|cl|}
\hline Local well number & Unit \\
\hline 25N/01E-03K01 & Qva \\
25N/01E-05A04 & Qva \\
$25 N / 01 E-17 N 01$ & Qva \\
$26 N / 01 E-14 C 01$ & QC1 \\
$26 N / 01 E-34 R 01$ & QC1pi \\
26N/01W-25L02 & QA1 \\
\hline
\end{tabular}

Man-made organic compounds were detected in two of these wells (25N/01E-17N01 and 26N/01W-25L02, see "Results of the Investigation"), and although no man-made organics were detected in the well, potential organic contamination is being investigated near $25 \mathrm{~N} /$ 01E-05A04; therefore, these three wells were excluded from the determination of ambient background levels of inorganics. No explanation for the anomalies other than natural variation became apparent during review of field notes and other available information about the other three wells, so the data for those wells were included in the determination of ambient background levels.

Because ambient background levels of inorganic constituents sometimes vary among hydrogeologic units, the suitable wells were grouped according to the hydrogeologic unit to which each well is open for determination of 50th and 90th percentile ambient background levels. Samples from 3 Qvt wells, 54 Qva wells, 34 QClpi wells, 16 QC1 wells, and 29 QA1 wells were analyzed for common ions, iron, and manganese (table 1), and samples from 2 Qvt wells, 40 Qva wells, 19 QC1pi wells, 8 QC1 wells, and 13 QA1 wells were analyzed for trace elements (table 2); see Appendix B for constituents sampled at individual wells. Because only three Qvt wells met the criteria for sampling in this investigation, few conclusions about the ambient water in Qvt can be made, and the U.S. Navy may wish to sample additional wells open to Qvt in the future.

The ambient background level of any man-made organic compound generally is assumed to be "not detected" unless demonstrated otherwise; this sampling was intended to test this assumption by determining the frequencies of detections of organic compounds in wells open to each hydrogeologic unit. Samples collected from 1 Qvt well, 30 Qva wells, 5 QC1pi wells, 8 QC1 wells, and 6 QA1 wells were analyzed for VOCs (table 3); and samples collected from 1 Qvt well, 19 Qva wells, 3 QClpi wells, $6 \mathrm{QCl}$ wells, and $4 \mathrm{QA} 1$ wells were analyzed for ordnance and semi-volatile organic compounds (table 4). Organic compounds were detected in only 2 of 50 wells sampled, and in two different hydrogeologic units. Only 
in Qva were sufficient samples collected to confirm "not detected" ambient background levels for the compounds analyzed.

For inorganic constituents, ambient background levels are defined in this report by the 50th and 90th percentile values of the concentrations measured in each hydrogeologic unit. The 50th percentile (or median) best represents the average value, and the 90th percentile is a common upper value that is useful to regulators. The nonparametric $n$th percentile value is the value for which $n$ percent of the data are lower values and 100- $n$ percent are higher values; these percentiles are independent of the distribution of the data. Non-detect values were assigned values of one-half of the reporting limit for the constituent. If fewer than ten samples were collected for any constituent in a hydrogeologic unit, percentile values-except for a median-could not be calculated (Helsel and Hirsch, 1992); even a median calculated for a small sample size has limited value as an indication of the middle range of concentrations. Therefore, ambient background levels for Qvt were not determined, and ambient background levels for QC1 were determined only for a subset of the constituents.

Another method for determining 50th and 90th percentile values is suggested by the Washington State Department of Ecology (1992); however, this method requires that the data sets be lognormally distributed, and the data for most of the constituents in this study fail the required statistical test (W test) for lognormal distribution (Washington State Department of Ecology, 1992).

According to the State's requirement (W>0.842), only the following constituents (and in only the indicated hydrogeologic units) are lognormally distributed at the $\mathrm{P}<0.05$ level: arsenic in $\mathrm{QC} 1 \mathrm{pi}(\mathrm{W}=0.870, \mathrm{P}=0.013)$; iron $(\mathrm{W}=0.913, \mathrm{P}=0.023)$ and manganese $(\mathrm{W}=0.882, \mathrm{P}=0.004)$ in QA1; sulfate in Qva, QClpi, and QA1; barium and phosphate in both Qva and QClpi; sodium in QClpi and QA1; nitrate in Qva; and ammonia in QC1pi. None of the constituents are lognormally distributed in QC1. For data sets in which constituents are not lognormally distributed, the nonparametric method of determining 50th and 90th percentiles (described in the previous paragraph) is recommended in the State guidance document (Washington State Department of Ecology, 1992); for the purposes of this report, this method is considered to be appropriate for all constituents.

\section{Tools Used to Describe Ambient Water Quality}

Modified trilinear (Piper) diagrams, showing the water type of each well based on the dominant ions present in each sample, were used to describe the ambient chemistry in each hydrogeologic unit (Piper, 1944). To compare water types of different water samples, the percentages of cations and anions for each sample are plotted on a Piper diagram; an example Piper diagram showing water types represented in each area is shown in Appendix C. The diagrams do not show actual concentrations; measured concentrations are converted to percentages of milliequivalents for each sample to account for varying charges of the ion species. The water type is determined from the area of the diagram in which the sample is plotted: the location on the lower left plot defines the dominant cation(s), and the location on the lower right plot determines the dominant anion(s). Combined water types, where more than one cation or anion dominate, are common: to be defined as the sole dominant ion, an ion must account for at least 60 percent of the cation or anion sum (the sample will plot near one of the corners).

Boxplots were used to provide concise visual summaries for side-by-side comparison of the data in each hydrogeologic unit; the type of boxplot chosen for this report consists of a center line (the 50th percentile value, or median) splitting a rectangle defined by the 25 th and 75 th percentile values with "whiskers" extending to the 10th and 90th percentile values. The extreme 20 percent of the data (the highest and lowest 10 percent) are not shown. If there are many samples with the same value for a constituent, two or more of these percentile values may be the same: for example, if one-third of the values for a constituent are non-detects, then the 10th and 25th percentile values are both "non-detect," and the boxplot will not have a lower whisker. Data points are shown instead of boxplots when fewer than ten data points were available.

\section{WATER QUALITY IN THE VICINITY OF SUBASE BANGOR}

Data collected for this investigation were used to describe ambient ground-water quality in the study area, to identify wells where drinking water standards were not met or where any man-made organic compound was detected, and to define ambient background levels of inorganic constituents. Spatial variations and differences among hydrogeologic units also were identified. 


\section{Characterization of Ambient Water Quality}

Most of the ground water in the study area has similar common-ion chemistry. Piper diagrams for all wells in the study area (fig. 4) and for the wells open to each hydrogeologic unit (Appendix C) show that the dominant cations are calcium and magnesium, with a slight shift to more calcium (and more sodium and potassium in a few wells) in the deeper units; and the dominant anion is bicarbonate $\left(\mathrm{HCO}_{3}\right)$, regardless of hydrogeologic unit. One well in QC1 had a very unusual water type (see fig. 4e). This well, located just outside of Poulsbo (26N/01E-14C01, see fig. 3), had the highest sodium concentration in the study area $(39 \mathrm{mg} / \mathrm{L}$, more than twice the next highest concentration of sodium).

The $\mathrm{pH}$ of the ground water in the study area ranged from 6.6 to 8.8 standard units. Nine wells with $\mathrm{pH}$ outside the recommended range of 6.5 to 8.5 standard units (U.S. Environmental Protection Agency, 1994b) were located in the northern part of study area (fig. 5). Dissolved oxygen concentrations less than $1 \mathrm{mg} / \mathrm{L}$ were measured in 48 wells located throughout the study area (fig. 5). The specific conductance of the ambient ground water ranged from 89 to 311 microsiemens per centimeter $(\mu \mathrm{S} / \mathrm{cm})$ and was generally between about 100 and $250 \mu \mathrm{S} / \mathrm{cm}$. The well determined to be contaminated by localized activities
(25N/01E-17N01, see fig. 3) had a specific conductance of $661 \mu \mathrm{S} / \mathrm{cm}$ (below the SMCL of $700 \mu \mathrm{S} / \mathrm{cm}$ set by the Washington State Department of Health, 1995). Dissolved solids concentrations ranged from 66 to $191 \mathrm{mg} / \mathrm{L}$, except in $25 \mathrm{~N} / 01 \mathrm{E}-17 \mathrm{~N} 01$, which had $413 \mathrm{mg} / \mathrm{L}$ dissolved solids (below the SMCL of $500 \mathrm{mg} / \mathrm{L}$ set by the Washington State Department of Health, 1995 and U.S. Environmental Protection Agency, 1994b). The wells sampled during this study generally had low concentrations of nutrients. Only five wells had nitrate plus nitrite concentrations greater than $2 \mathrm{mg} / \mathrm{L}$. The highest concentration was $6.3 \mathrm{mg} / \mathrm{L}$, below the MCL for nitrate ( $10 \mathrm{mg} / \mathrm{L}$, see table 6$)$. The highest nitrite concentration was $0.3 \mathrm{mg} / \mathrm{L}$, also below the MCL (1 mg/L).

Most of the data that describe the ambient water quality of the study area are presented in the boxplots shown on figure 6 for field measurements (including $\mathrm{pH}$, dissolved oxygen, and specific conductance) and the constituents listed in tables 1 and 2, grouped by hydrogeologic unit. The reporting level, SMCL, and MCL for each constituent also are indicated as explained on the figure below. Boxplots are not shown for cadmium, copper, silver, and zinc due to suspected field contamination of samples for these constituents (see "Quality Assurance and Control Samples" in the Approach and Methods section).

\begin{tabular}{|c|c|c|}
\hline \multirow{3}{*}{$(28)=$ (number of samples) } & \multicolumn{2}{|c|}{ Hydrogeologic units } \\
\hline & Qvt & Vashon till confining unit \\
\hline & Qva & Vashon aquifer \\
\hline 1 -75th percentile value & $\widehat{Q} C 1 p i$ & Permeable interbeds \\
\hline & QC1 & Upper confining unit \\
\hline 50 th percentile value & QA1 & Sea-level aquifer \\
\hline or median & * & Data point(s) \\
\hline & ...... & .. Reporting level \\
\hline$\longrightarrow 25$ th percentile value & -- & - SMCL \\
\hline$\perp \_$10th percentile value & & - MCL \\
\hline
\end{tabular}




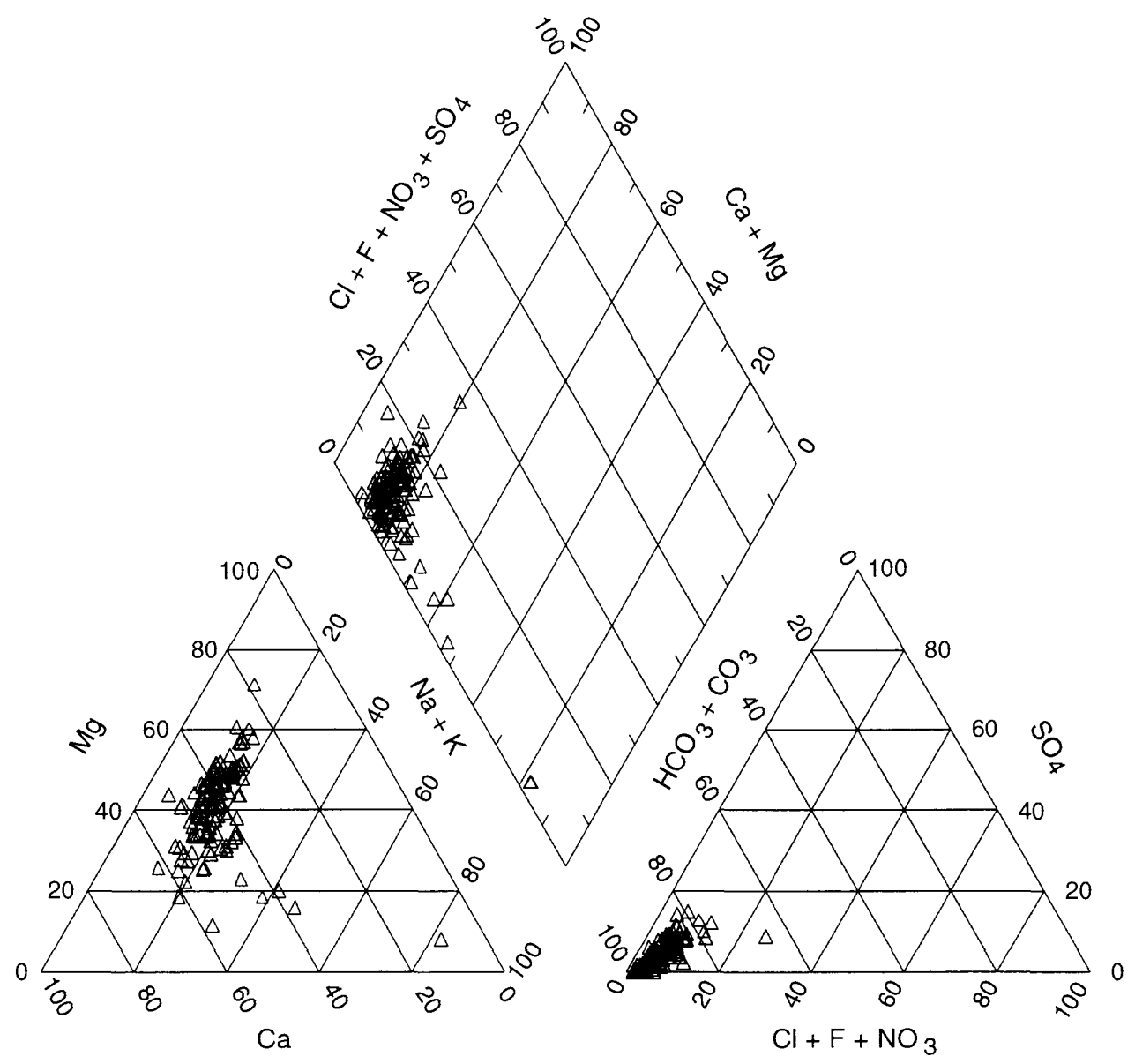

Figure 4a. Piper diagram for all major-ion samples collected in the study area. Numbers are percentages. See page 15 for explanation. 


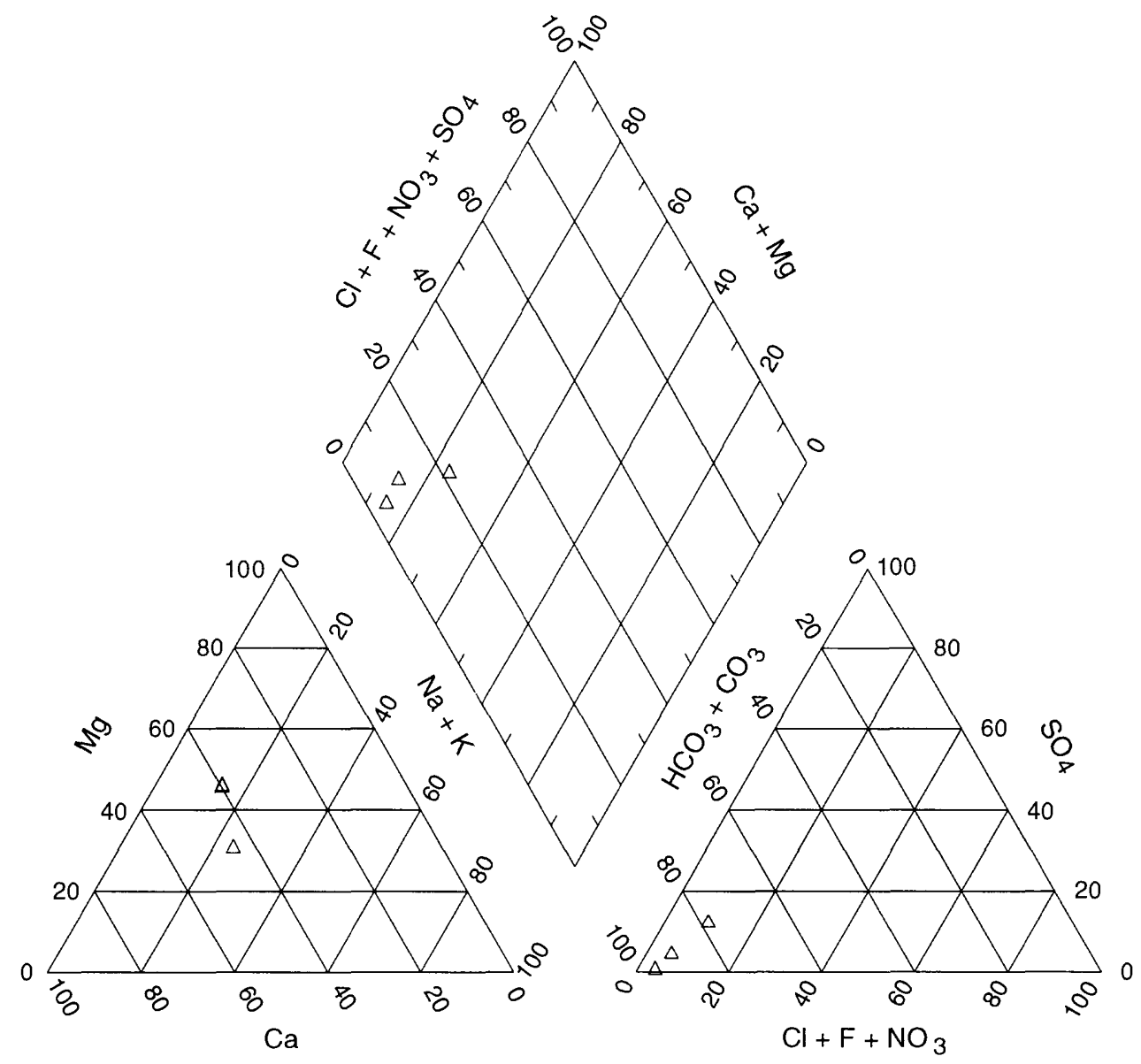

Figure 4b. Piper diagram for all samples collected from the Vashon till confining unit (Qvt). 


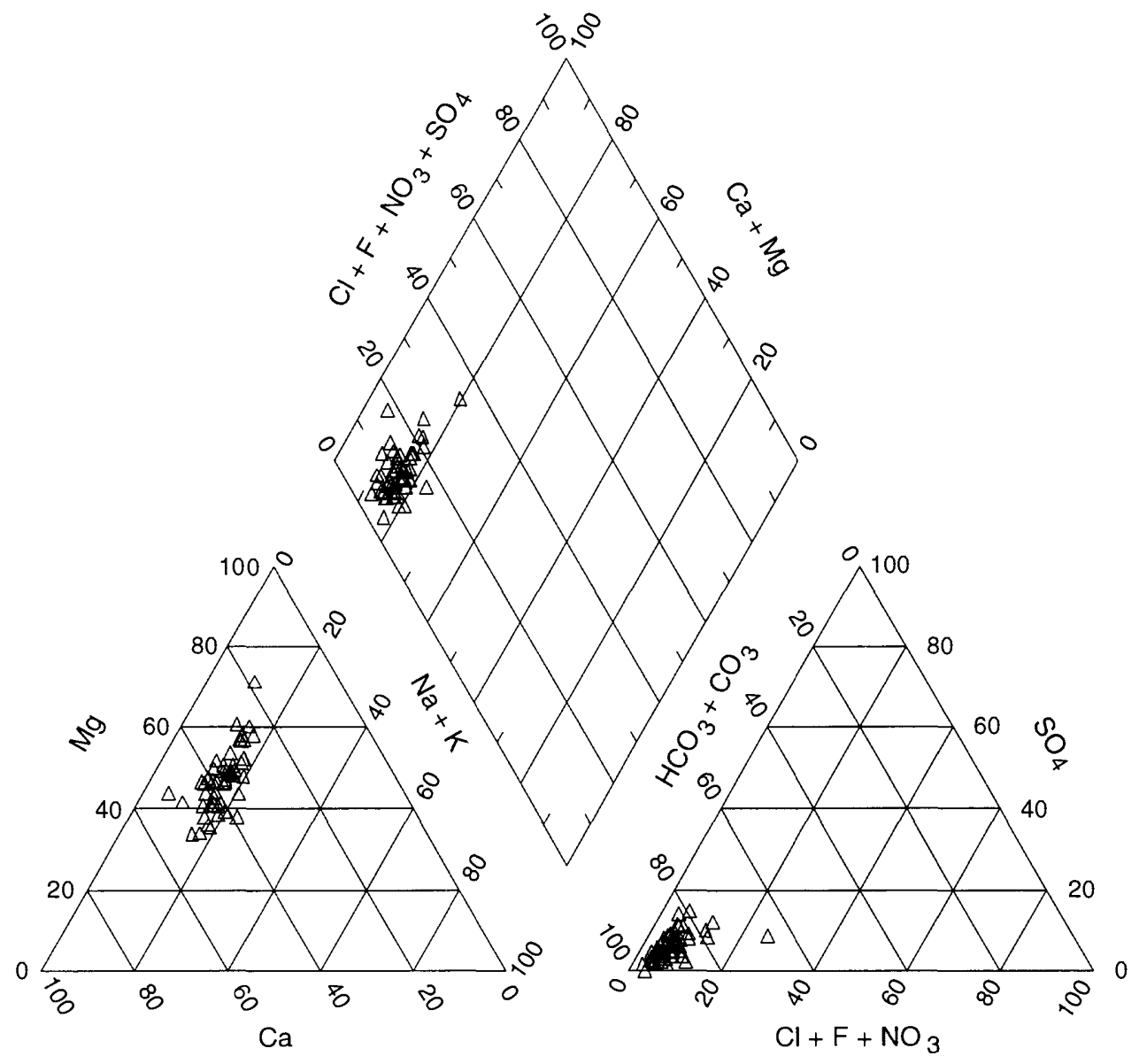

Figure 4c. Piper diagram for all samples collected from the Vashon aquifer (Qva). 


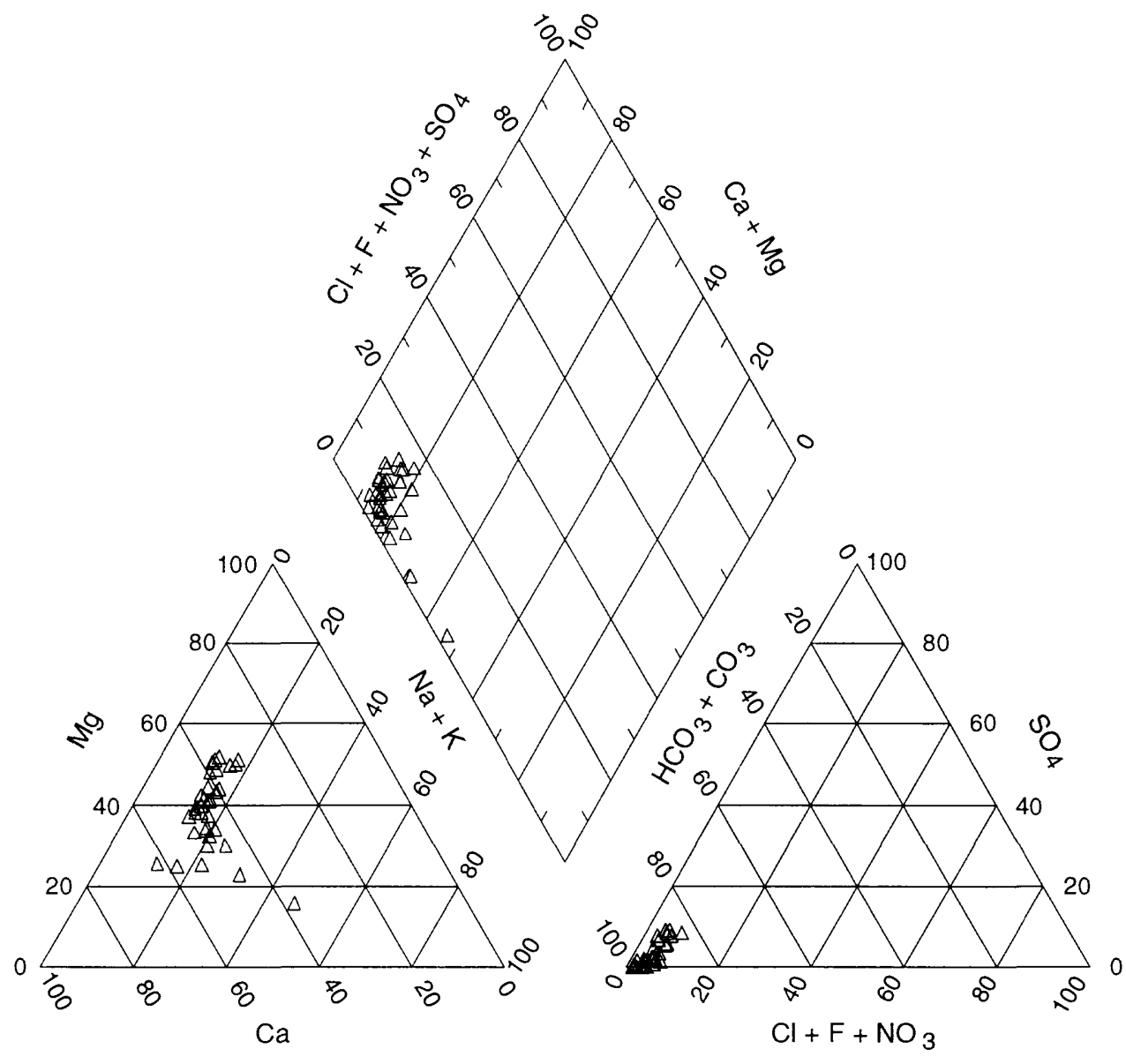

Figure 4d. Piper diagram for all samples collected from the permeable interbeds (QC1pi). 


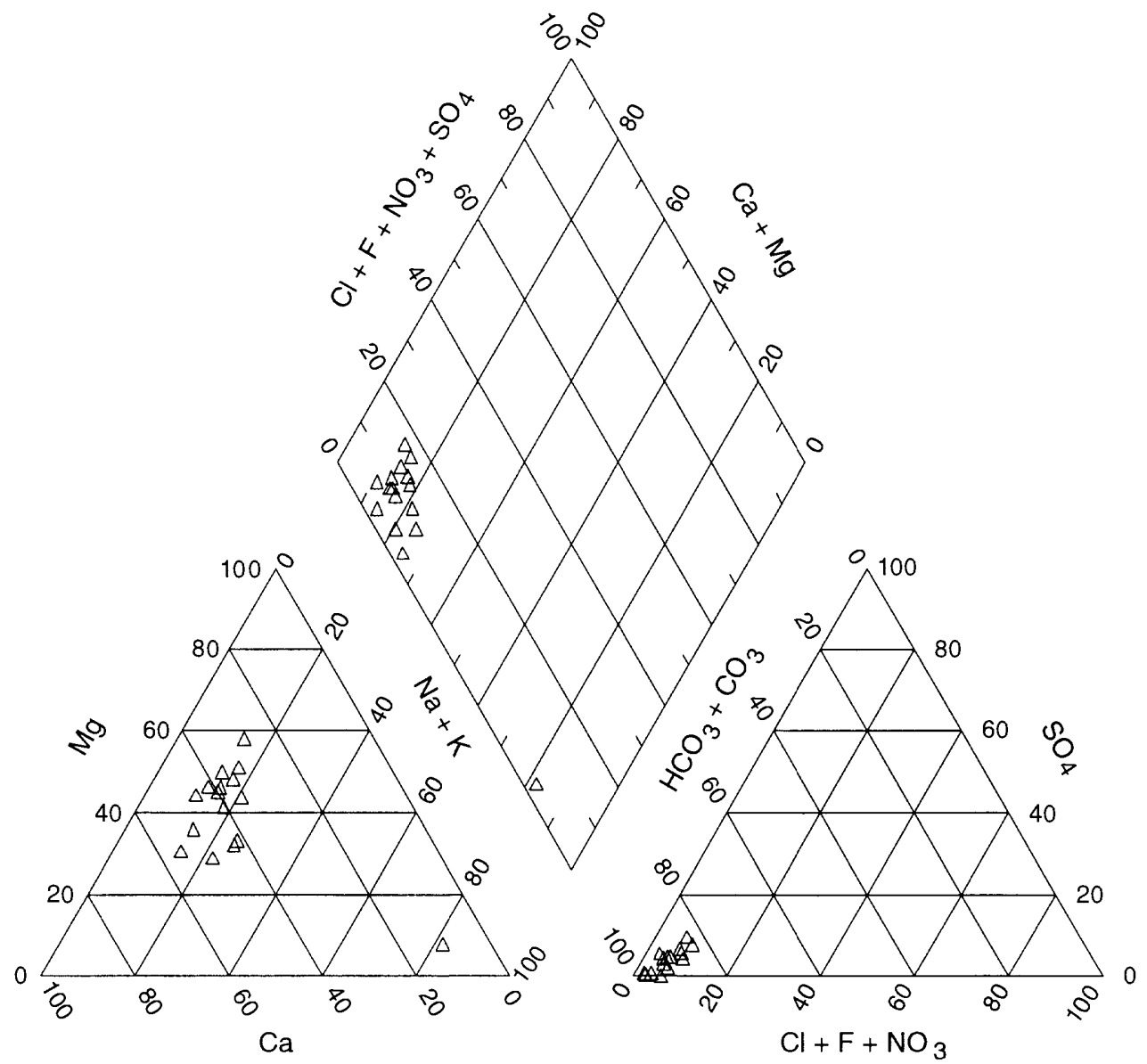

Figure 4e. Piper diagram for all samples collected from the upper confining unit (QC1). 


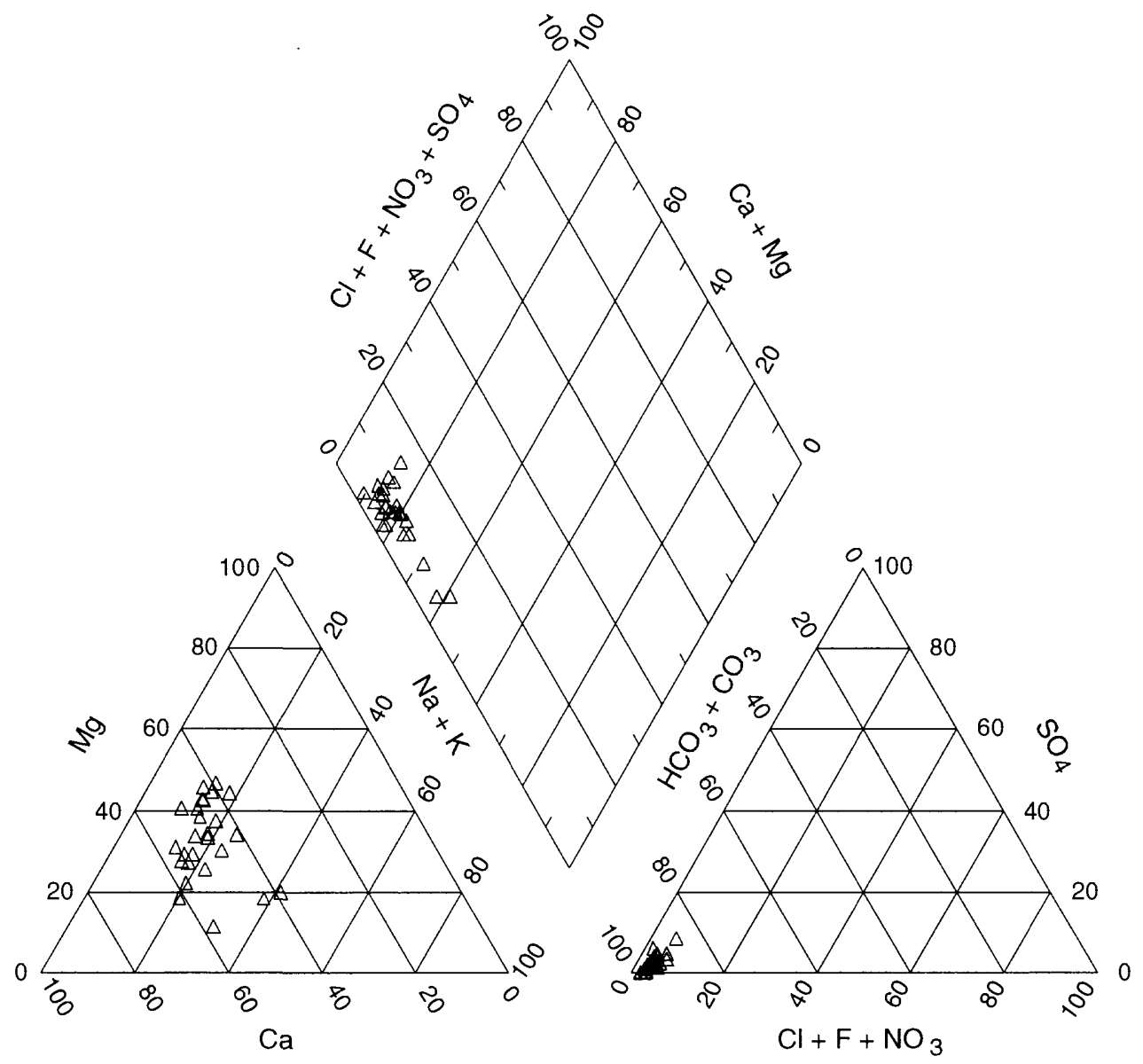

Figure 4f. Piper diagram for all samples collected from the sea-level aquifer (QA1). 


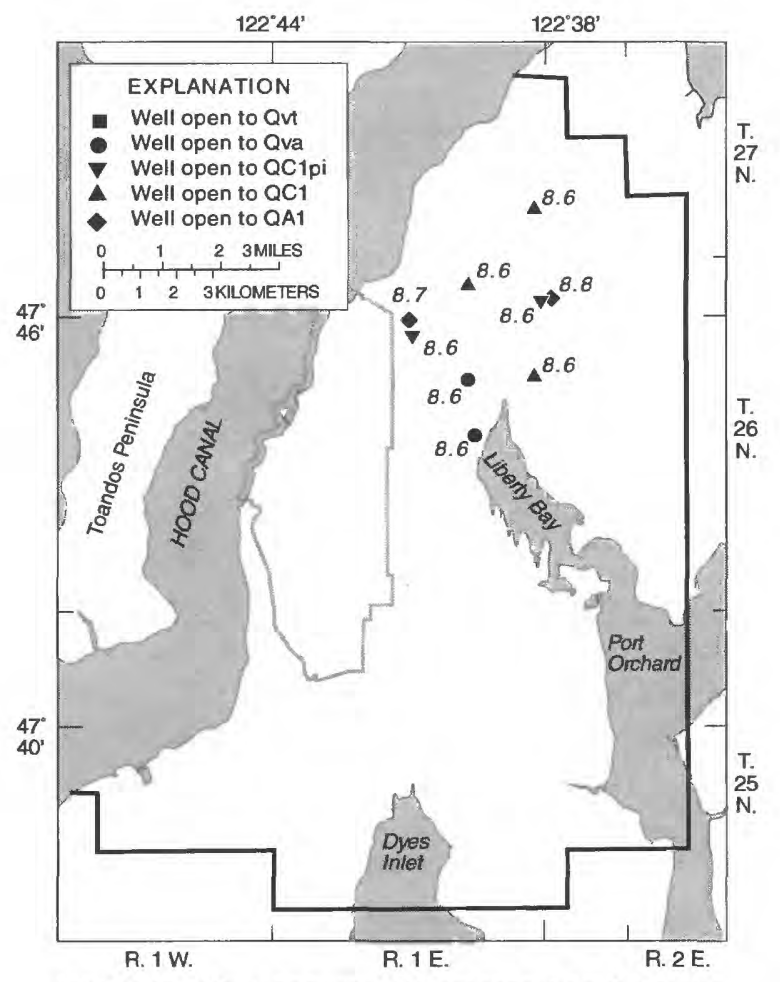

(a) Wells with measured $\mathrm{pH}$ greater than 8.5 units. Values are standard units.

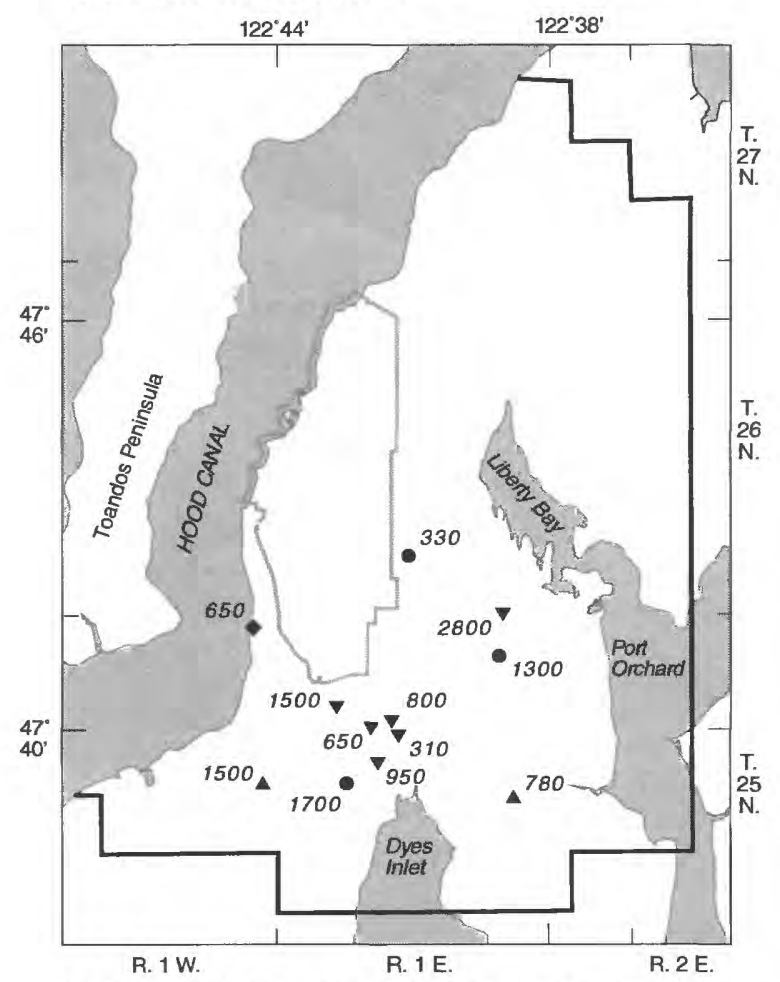

(c) Wells with iron concentration greater than 300 micrograms per liter $(\mu \mathrm{g} / \mathrm{L})$. Values are in $\mu \mathrm{g} / \mathrm{L}$.

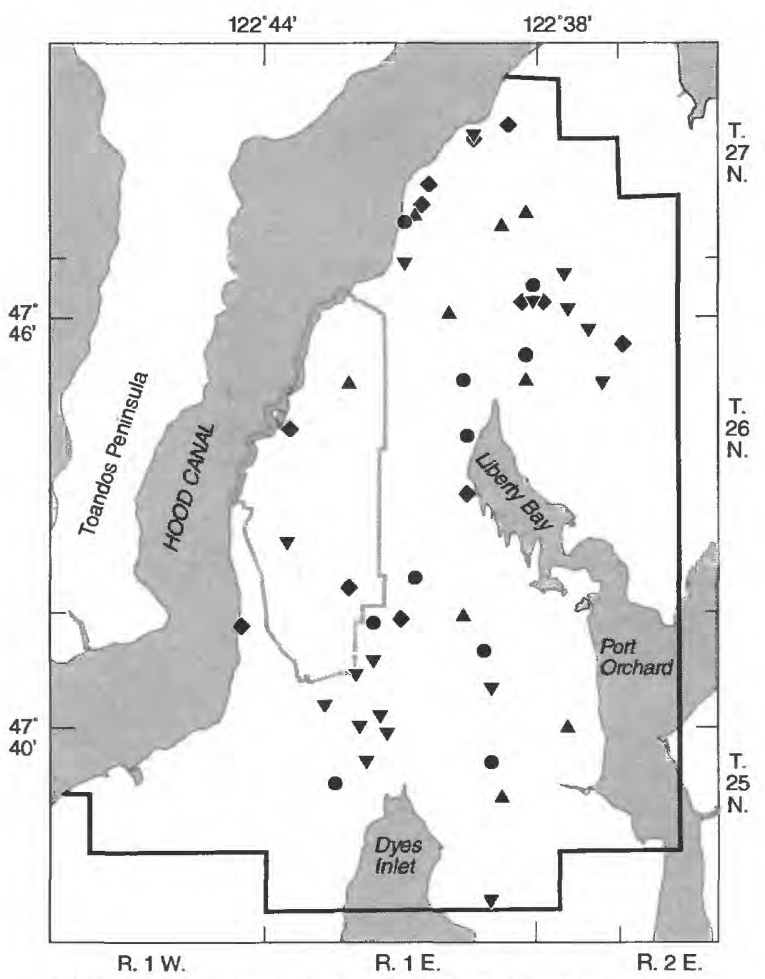

(b) Wells with measured dissolved oxygen concentration less than 1.0 micrograms per liter $(\mu \mathrm{g} / \mathrm{L})$.

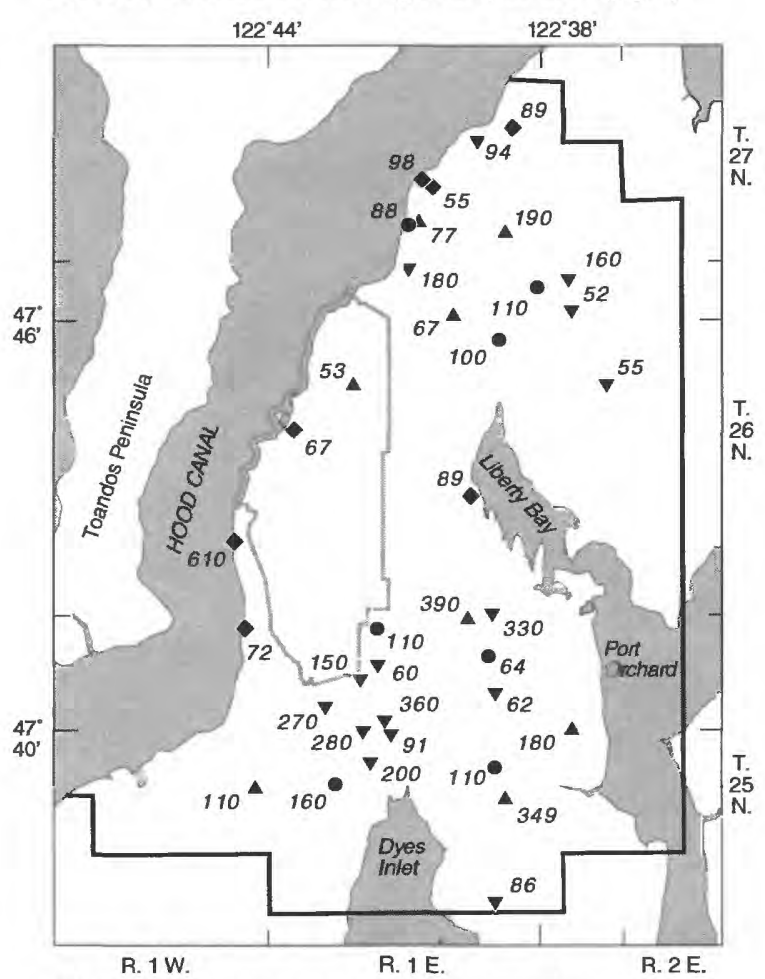

(d) Wells with manganese concentration greater than 50 micrograms per liter $(\mu \mathrm{g} / \mathrm{L})$. Values are in $\mu \mathrm{g} / \mathrm{L}$.

Figure 5. Wells with high measured $\mathrm{pH}$, low measured dissolved oxygen, iron concentration exceeding the secondary maximum contaminant level (SMCL) of 300 micrograms per liter $(\mu \mathrm{g} / \mathrm{L})$, and manganese concentration exceeding the SMCL of $50 \mu \mathrm{g} / \mathrm{L}$. 

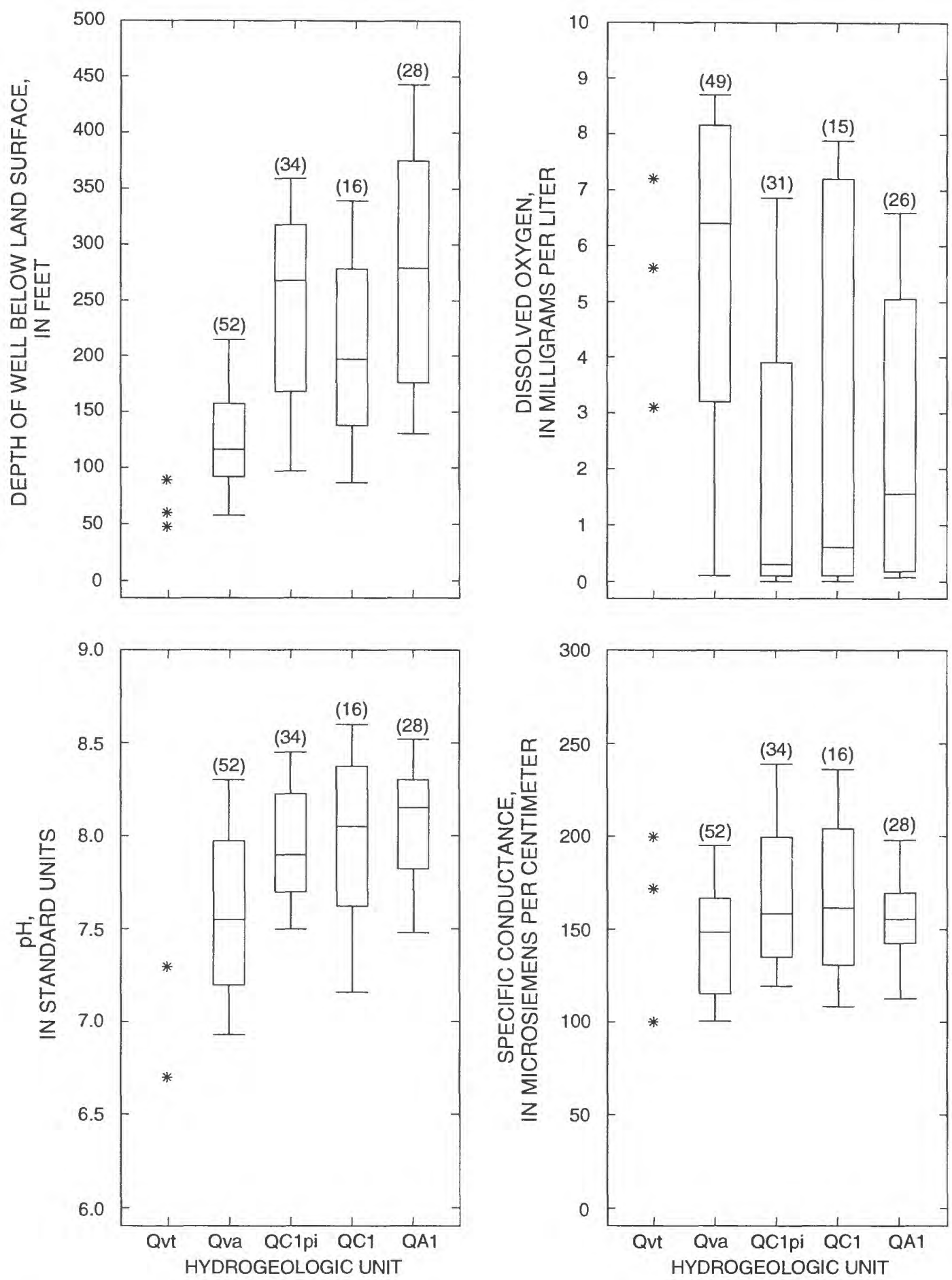

Figure 6. Boxplots of 40 constituents, grouped by hydrogeologic unit. See page 16 for explanation. 

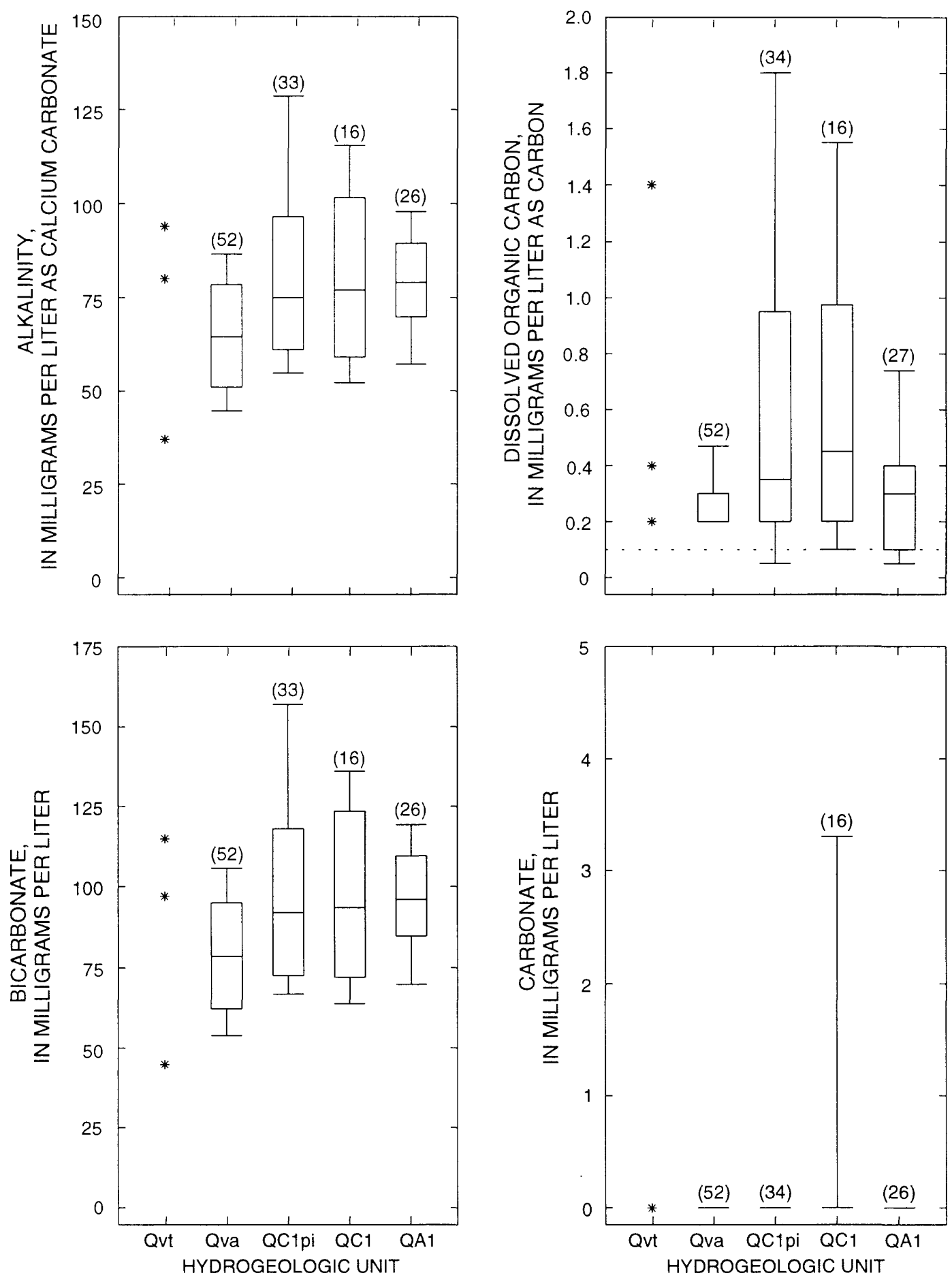

Figure 6. Continued 

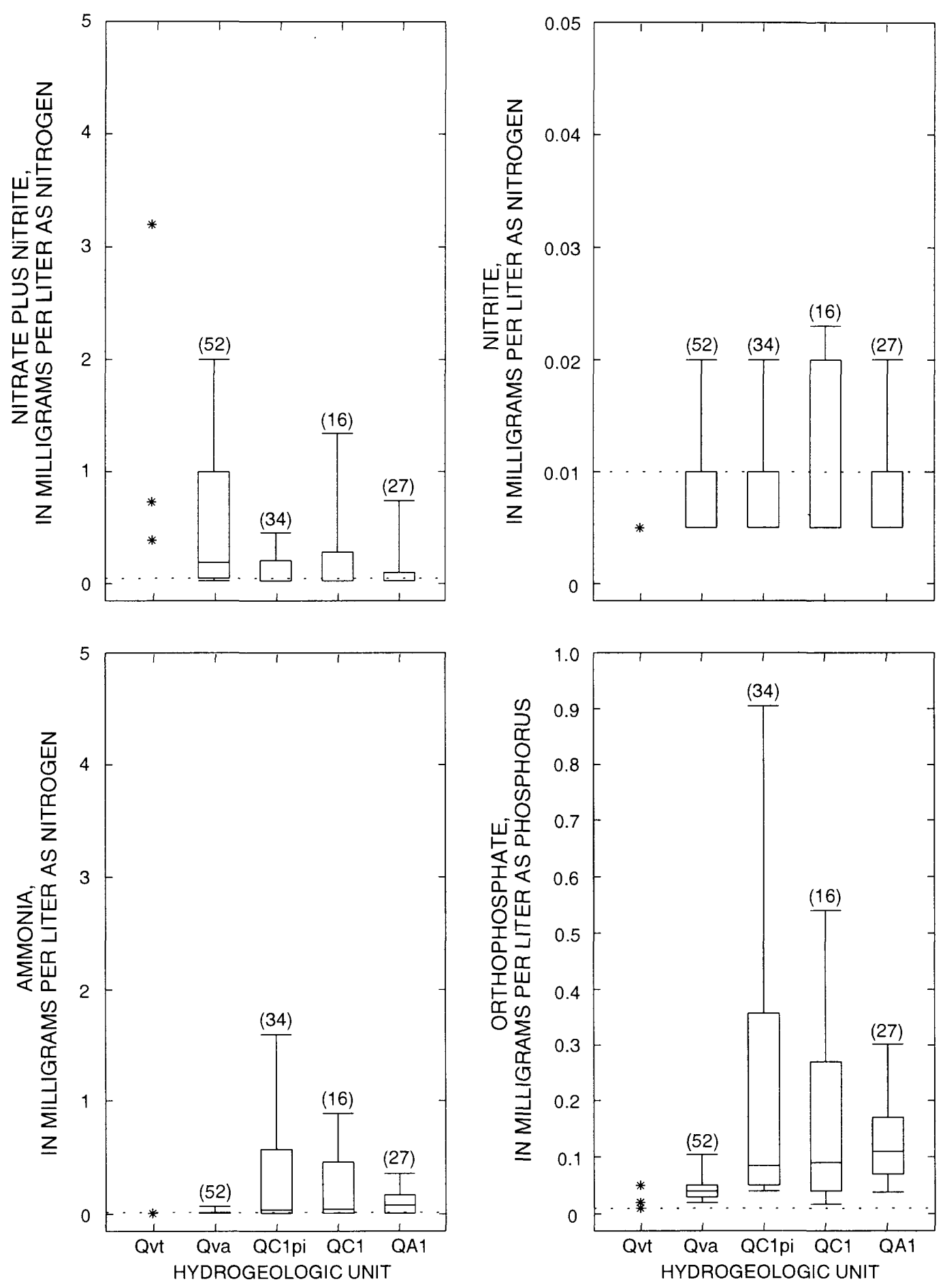

Figure 6. Continued 

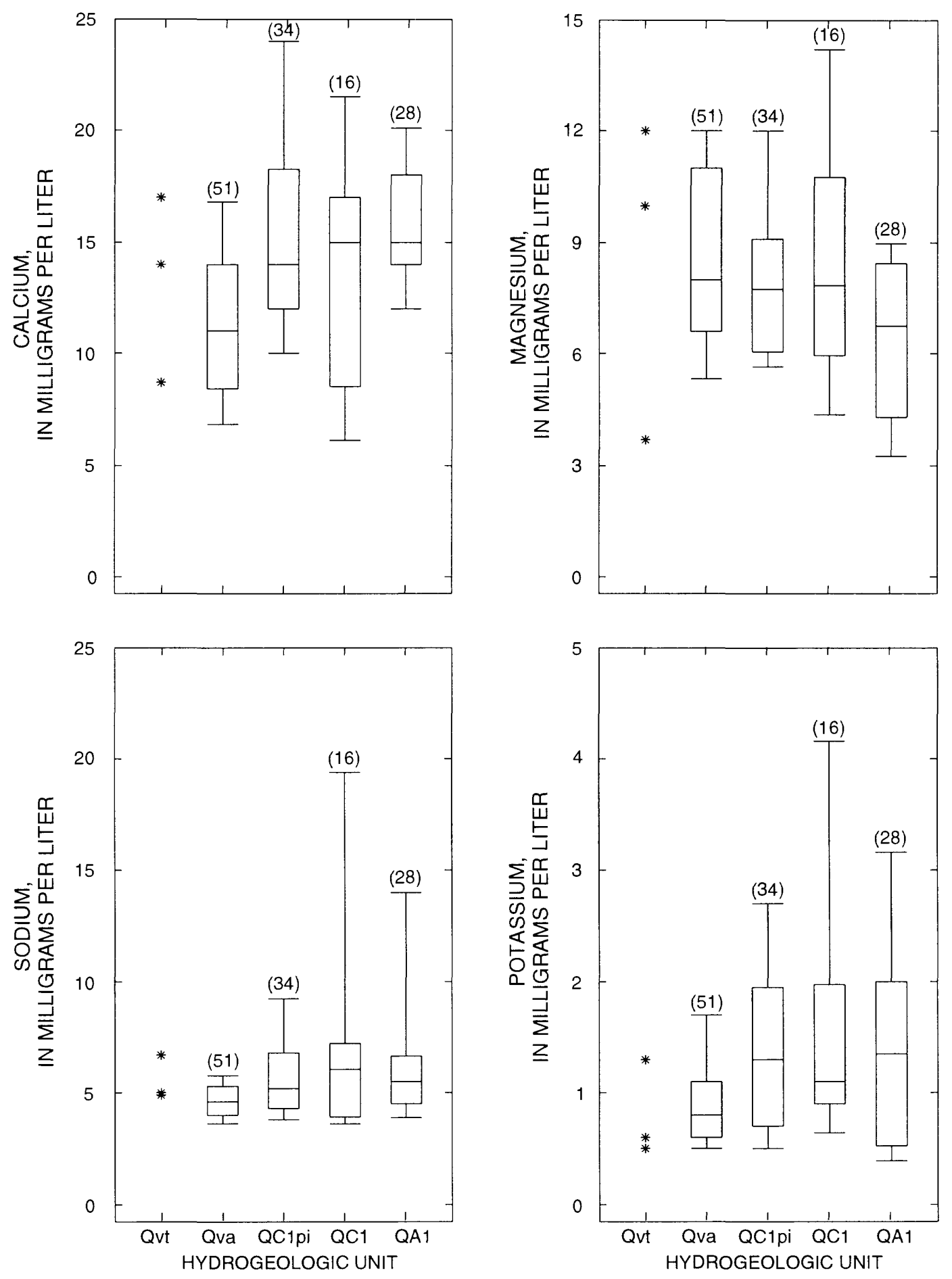

Figure 6. Continued 

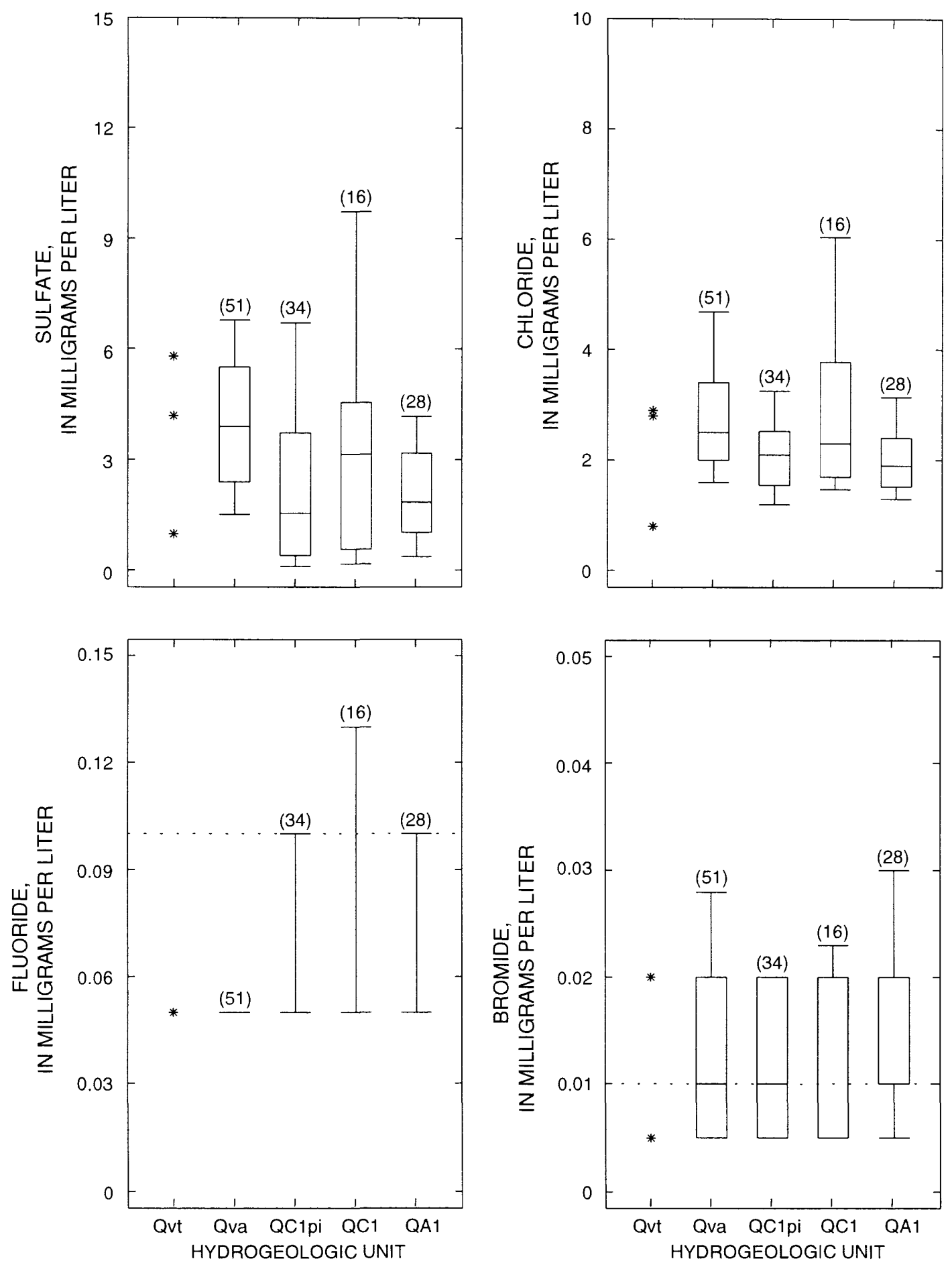

Figure 6. Continued 

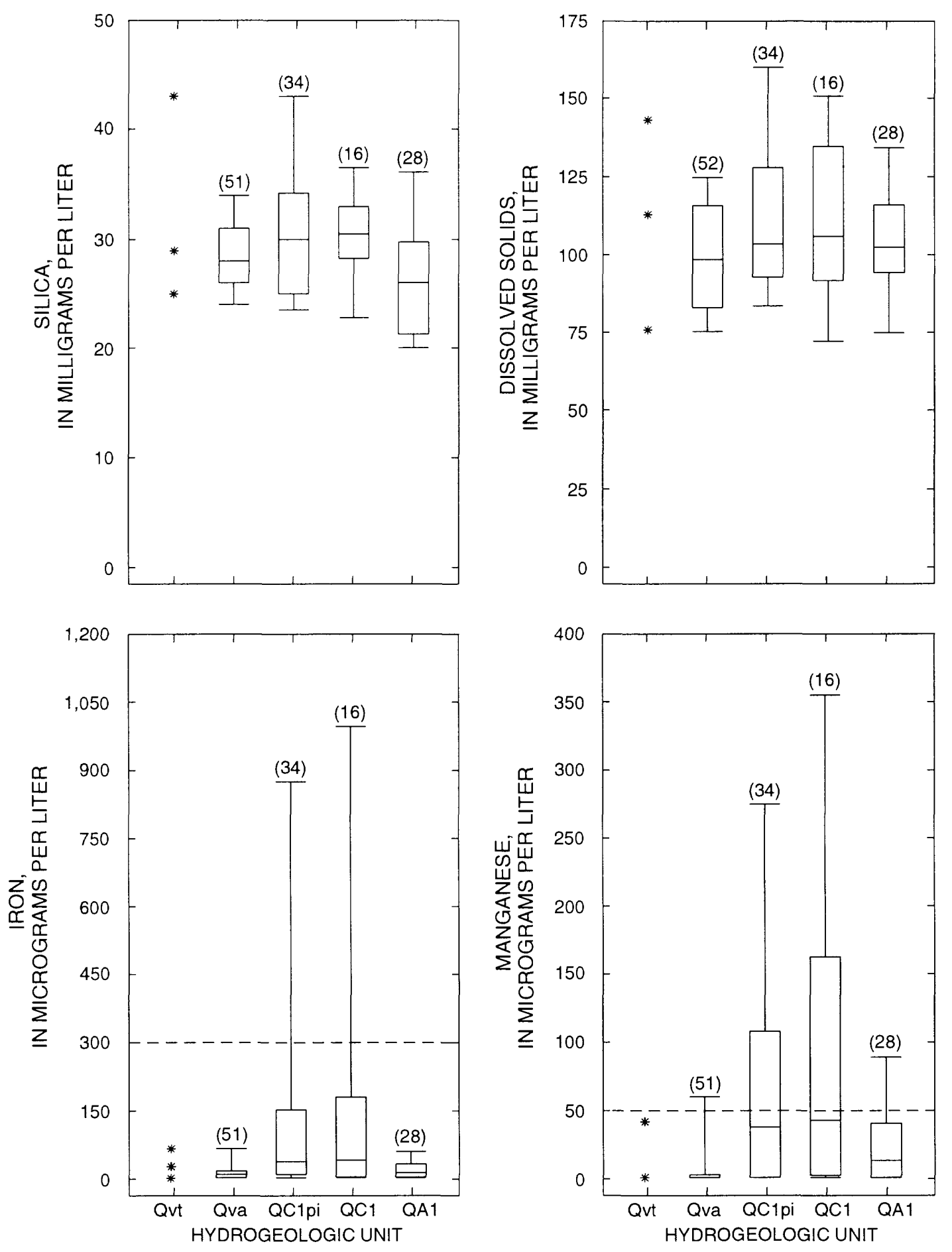

Figure 6. Continued 

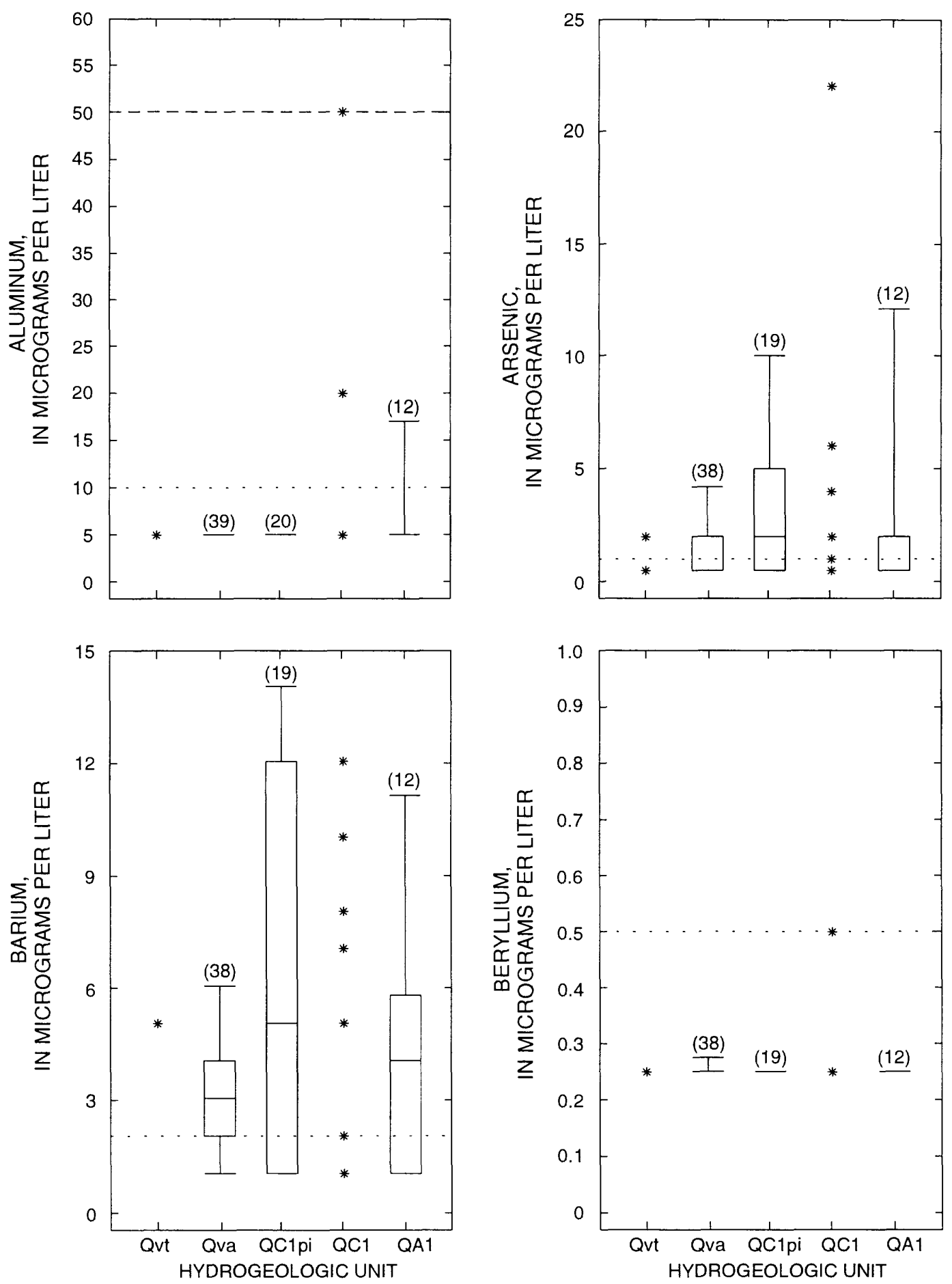

Figure 6. Continued 

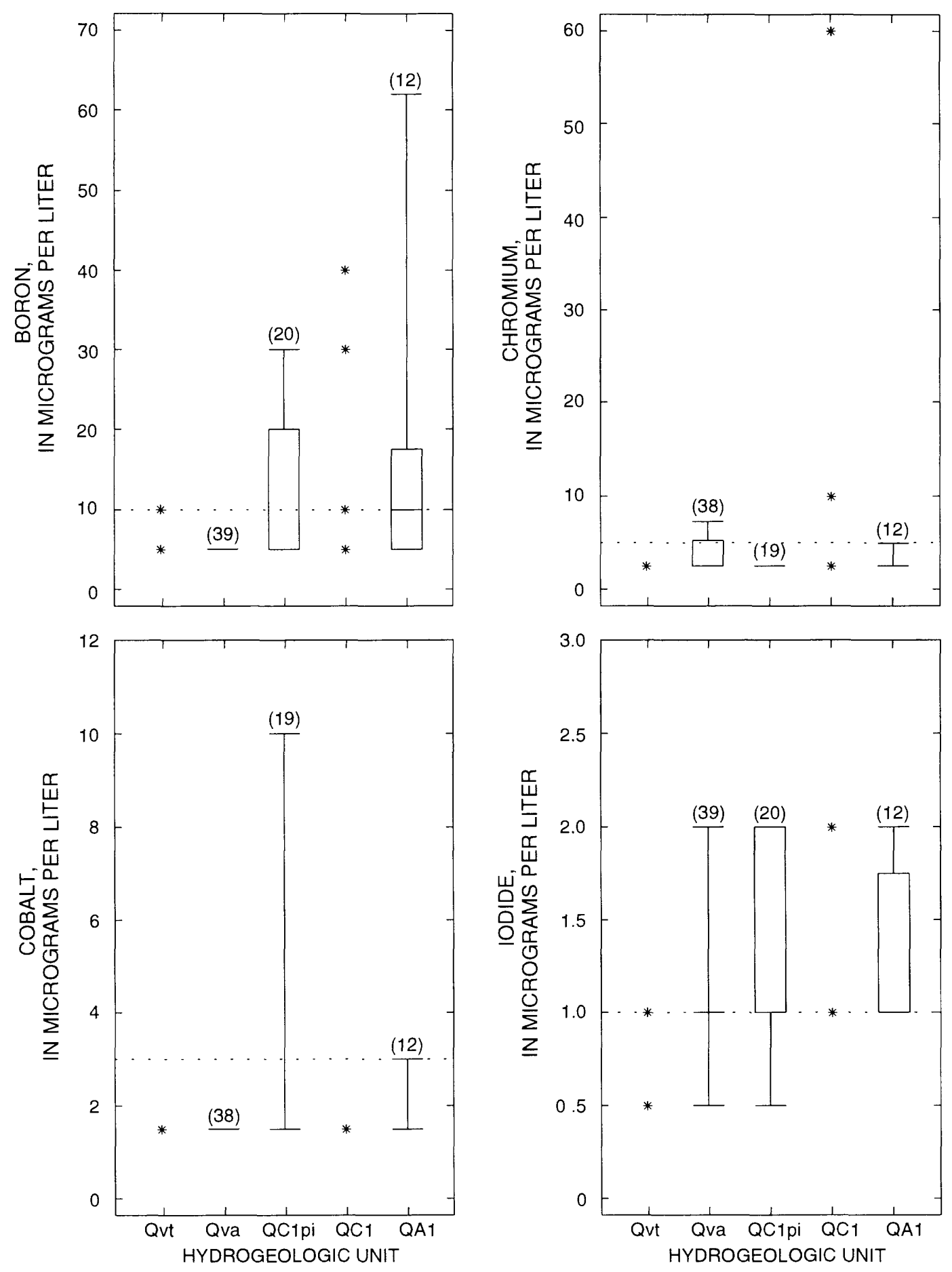

Figure 6. Continued 

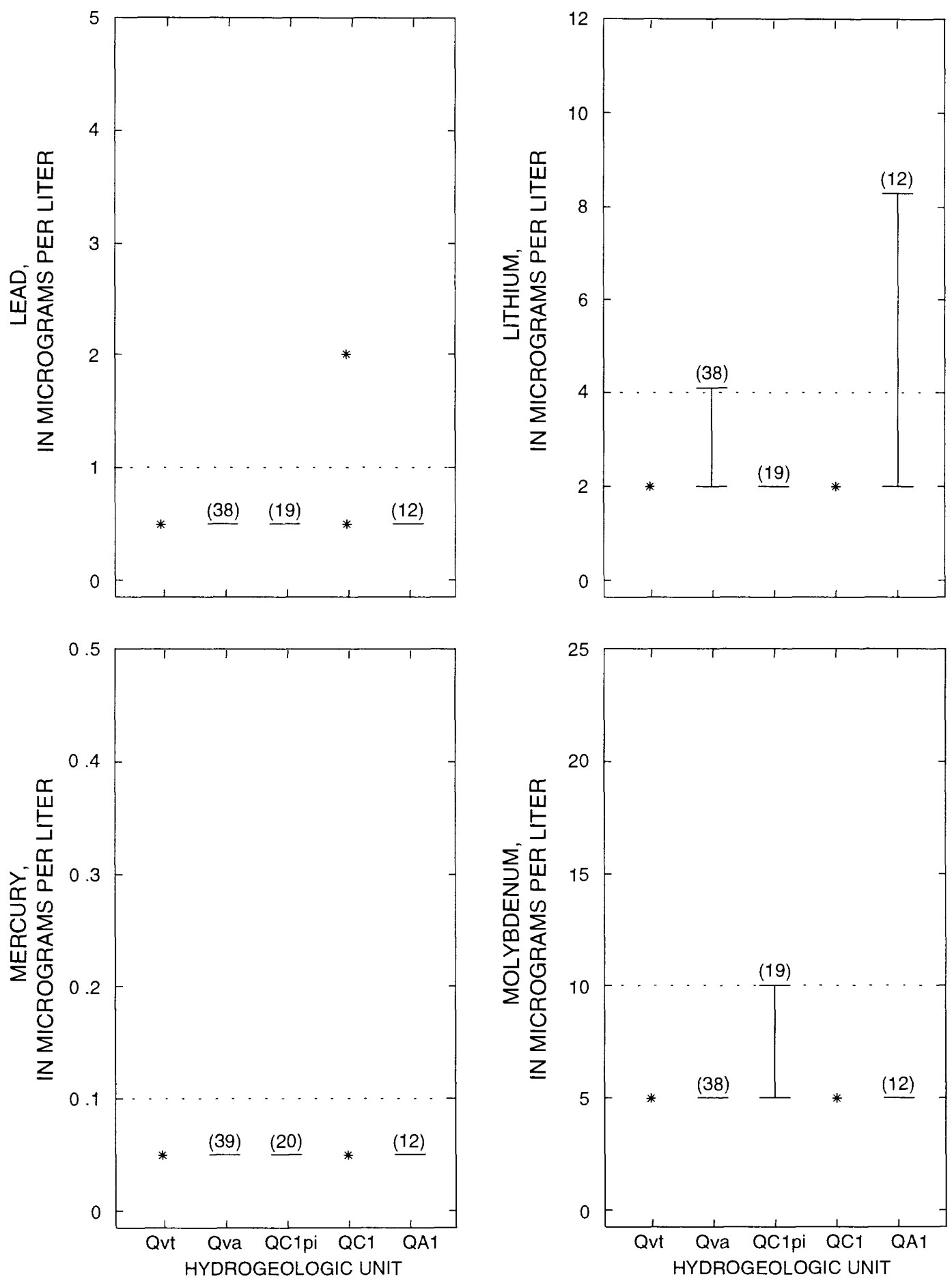

Figure 6. Continued 

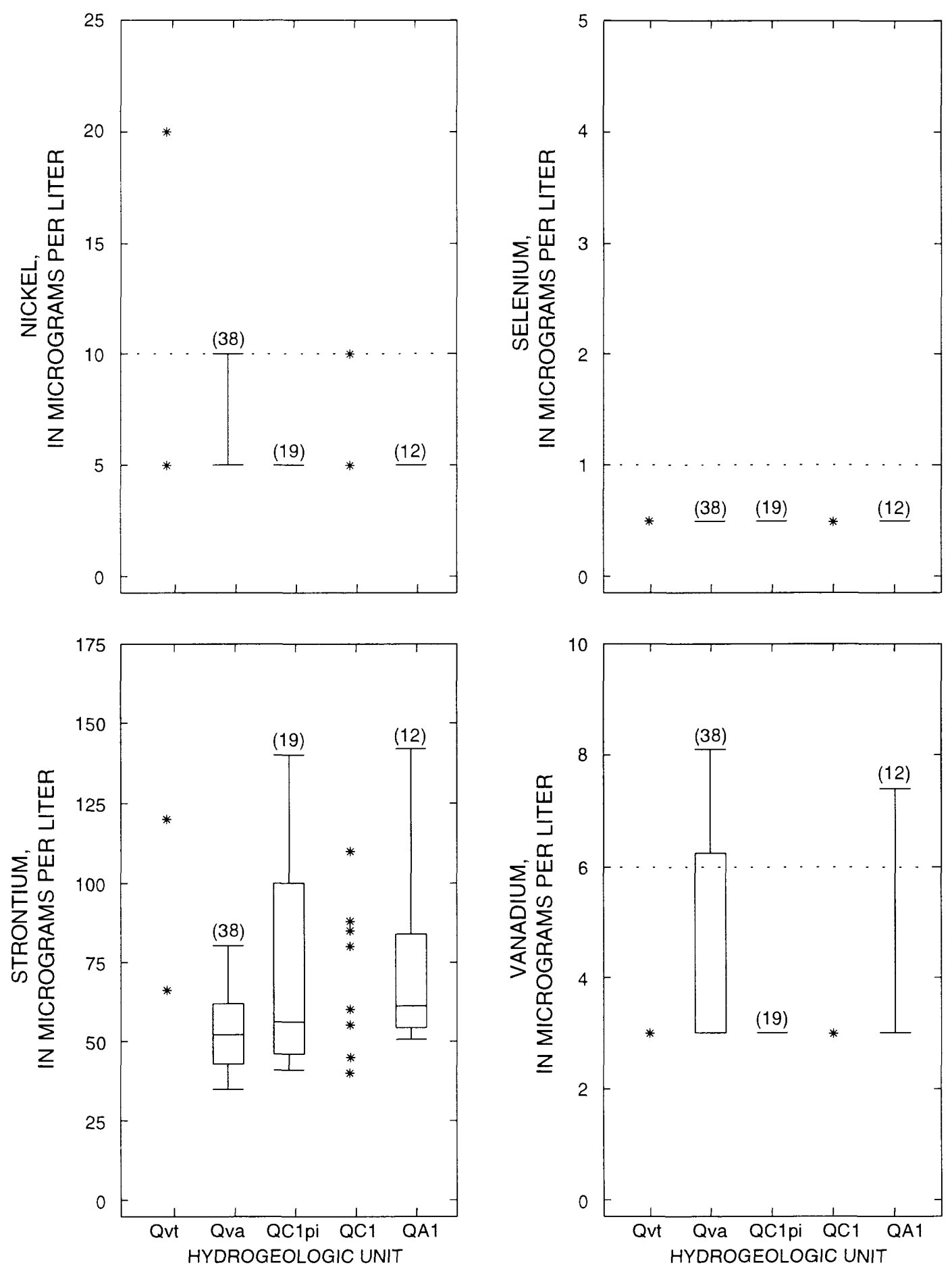

Figure 6. Continued 
Some general differences in ambient water quality from one hydrogeologic unit to another can be assessed by visual comparison of the medians shown in these boxplots: for instance, the median dissolved oxygen and sulfate concentrations are lower in the deeper units; the median $\mathrm{pH}$ and orthophosphate and calcium concentrations are higher in the deeper units. Iron and especially manganese concentrations are highest in QC1 and QC1pi.

Concentrations of iron and manganese exceeding SMCLs $(300 \mu \mathrm{g} / \mathrm{L}$ and $50 \mu \mathrm{g} / \mathrm{L})$ were detected in many wells; most of these wells also had low concentrations (less than $1 \mathrm{mg} / \mathrm{L}$ ) of dissolved oxygen (fig. 7; also see fig. 5). High iron and manganese concentrations generally occur in the same sample (fig. 7); however, the SMCL of manganese was exceeded in 38 wells, and the SMCL of iron was exceeded in only 12 wells (fig. 5). The wells with manganese exceeding the SMCL are located throughout the study area, and the wells with iron exceeding the SMCL are located mostly in the southern part of the study area (fig. 5).

The concentration of dissolved organic carbon (DOC) is an approximate measurement of the total amount of organic material in ground water, which may substantially affect concentrations of metals (Hem, 1985). DOC was measured in samples from all of the wells and ranged from less than $0.1 \mathrm{mg} / \mathrm{L}$ to $3.1 \mathrm{mg} / \mathrm{L}$, with a median concentration of $0.3 \mathrm{mg} / \mathrm{L}$ for the study area. In general, wells in the study area with higher concentrations of DOC (greater than about $1 \mathrm{mg} / \mathrm{L}$ ) also had low concentrations (less than $1 \mathrm{mg} / \mathrm{L})$ of dissolved oxygen and high concentrations (above SMCLs) of both iron and manganese (fig. 7). The oxidation of larger amounts of organic carbon probably results in low dissolved-oxygen conditions suitable for chemical reduction--and increased solubility--of iron and manganese.

No samples exceeded MCLs for trace elements. Figure 8 shows the locations of wells sampled for trace elements and samples with $5 \mu \mathrm{g} / \mathrm{L}$ or more arsenic, $20 \mu \mathrm{g} / \mathrm{L}$ or more aluminum, and $10 \mu \mathrm{g} / \mathrm{L}$ or more chromium - these trace elements may be of particular drinking-water concern; others are discussed below. The MCLs for arsenic and chromium are $50 \mu \mathrm{g} / \mathrm{L}$ and $100 \mu \mathrm{g} / \mathrm{L}$, and the SMCL for aluminum is $50 \mu \mathrm{g} / \mathrm{L}$ (table $6)$; one well (27N/01E-35C01) had a concentration of aluminum equal to the SMCL. The wells having the two highest measurements of chromium were investigated further: a possible local source of contamination (a burn pile with metal parts) was discovered at the well-head where the sample $60 \mu \mathrm{g} / \mathrm{L}$ of chromium was collected $(27 \mathrm{~N} /$ 01E-33B02); and the well (26N/01 W-36R02) with $70 \mu \mathrm{g} / \mathrm{L}$ chromium was sampled again in June 1996 , and no chromium was detected. Data for both wells were included in the determination of ambient background levels because (1) the common-ion chemistry of the wells was not unusual and (2) there were insufficient data available for determination of ambient background levels of chromium and other trace elements in QC1 (27N/ $01 \mathrm{E}-33 \mathrm{~B} 02$ is open to QC1).

Mercury and selenium were not detected in any of the samples collected in the study area. The following trace elements were detected in fewer than ten samples: lead was detected in two samples, beryllium in four samples, copper in four samples, lithium in six samples, molybdenum in seven samples, cobalt in eight samples, and nickel in eight samples. The presence of copper, nickel, or lead in any sample may indicate contamination from the plumbing of a well; however, neither detection of lead coincided with detections of copper as would be expected if the lead came from the plumbing. Detections of copper, nickel, and silver in the sample collected from a Qvt well (26N/01E-32E05, see fig. 3) indicate certain contamination from the plumbing at the site. Additionally, galvanized well-casing materials, common in water-supply wells, may have contaminated most of the ground-water samples with zinc, which was detected in all but five samples. The highest measured zinc concentration, $290 \mu \mathrm{g} / \mathrm{L}$, was substantially below the SMCL of $5,000 \mu \mathrm{g} / \mathrm{L}$

(table 6). Cadmium was detected in eight wells at concentrations of 2 to $3 \mu \mathrm{g} / \mathrm{L}$ (the $\mathrm{MCL}$ is $5 \mu \mathrm{g} / \mathrm{L}$ ), but these measurements are questionable because up to $2 \mu \mathrm{g} / \mathrm{L}$ cadmium was detected in field blanks (see "Quality Analysis and Control Samples" in the Approach and Methods section). 

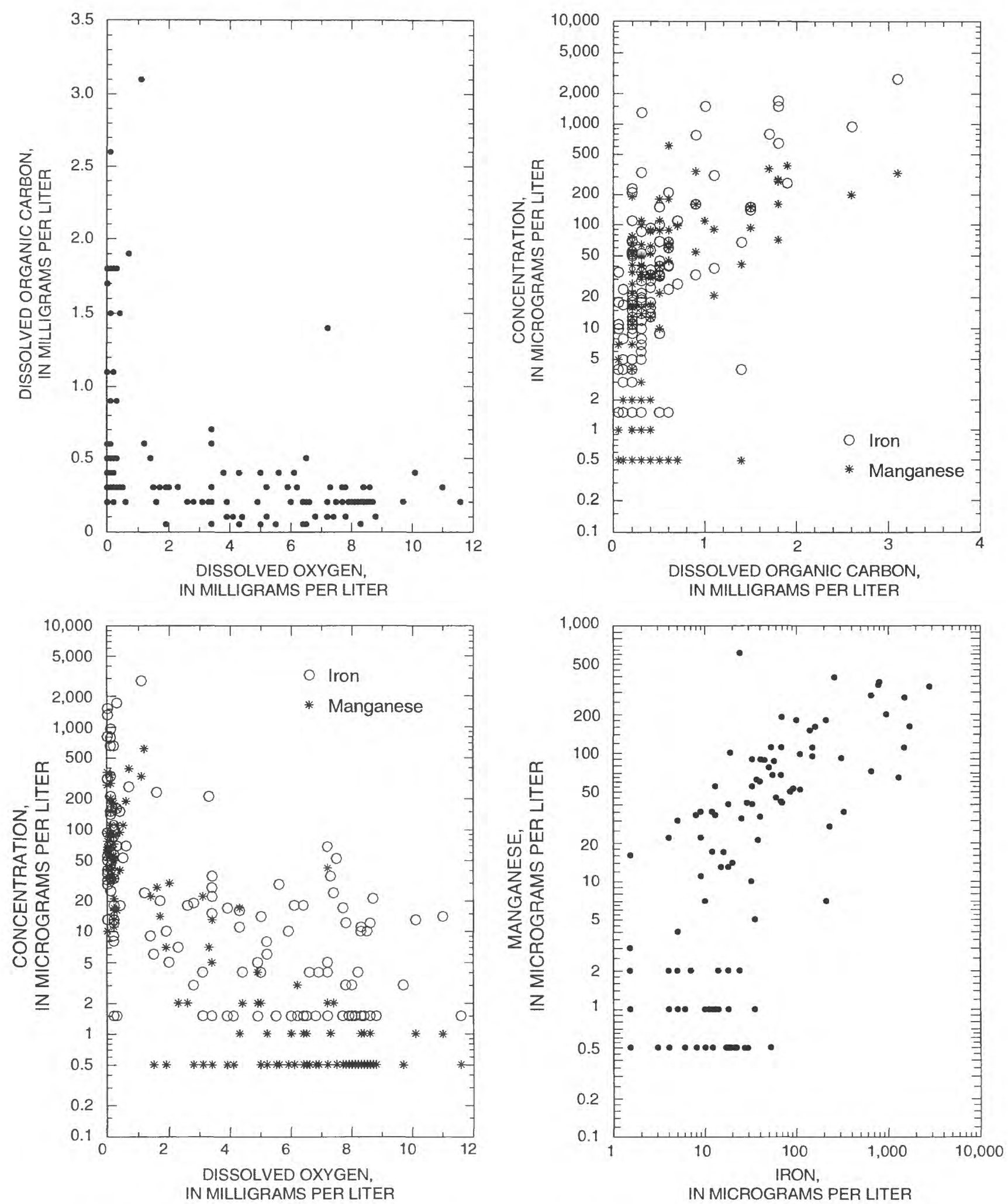

Figure 7. Relationships between concentrations of dissolved oxygen, dissolved organic carbon, iron, and manganese. The minimum reporting levels for iron and manganese are 3 micrograms per liter and 1 microgram per liter. 


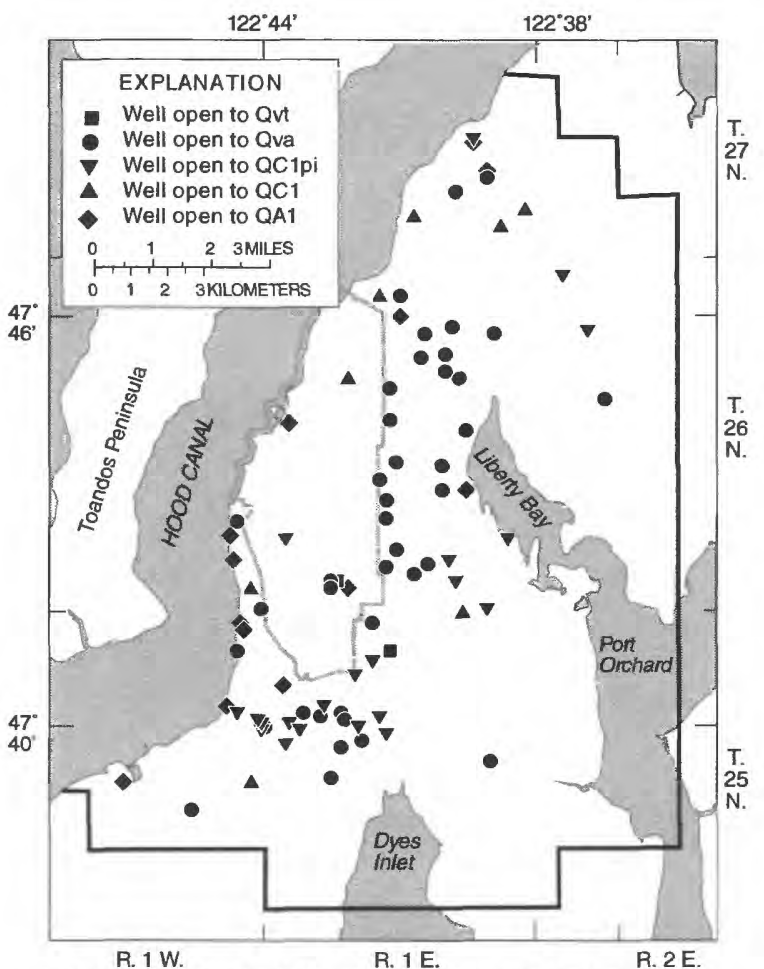

(a) Wells sampled for trace elements listed in table 2 .

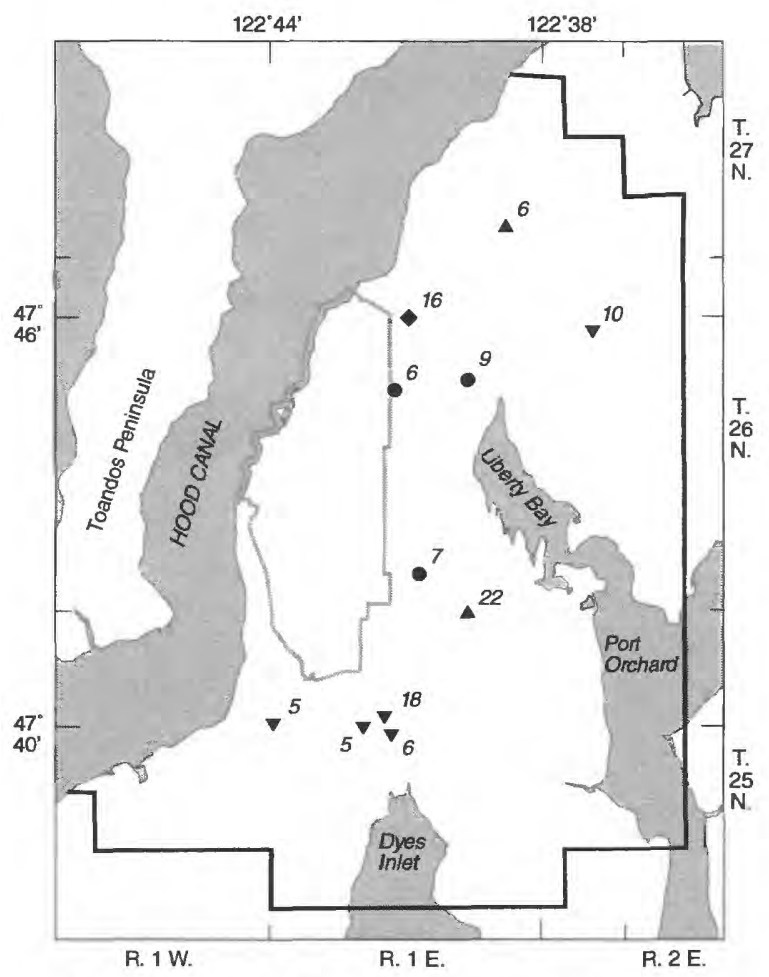

(c) Wells with 5 micrograms per liter $(\mu \mathrm{g} / \mathrm{L})$ or more arsenic. The maximum contaminant level for arsenic is $50 \mu \mathrm{g} / \mathrm{L}$.

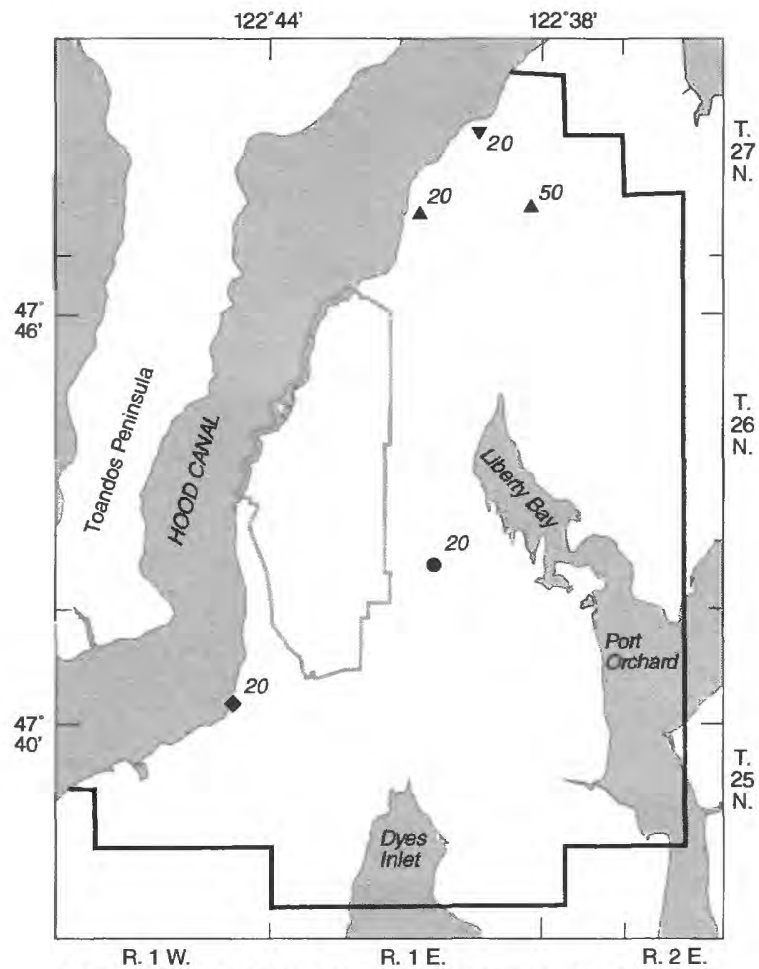

(b) Wells with 20 micrograms per liter ( $\mu \mathrm{g} / \mathrm{L}$ ) or more aluminum. The secondary maximum contaminant level for aluminum is $50 \mu \mathrm{g} / \mathrm{L}$.

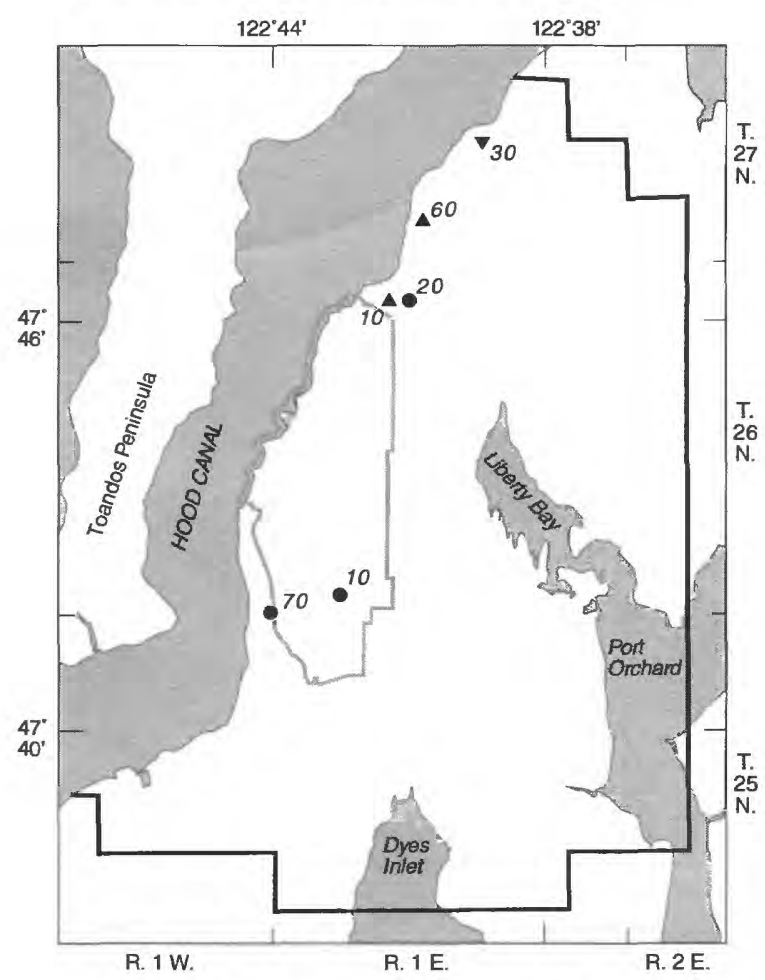

(d) Wells with 10 micrograms per liter $(\mu \mathrm{g} / \mathrm{L})$ or more chromium. The maximum contaminant level for chromium is $100 \mu \mathrm{g} / \mathrm{L}$.

Figure 8. Wells sampled for trace elements, and wells with concentrations of 20 micrograms per liter $(\mu \mathrm{g} / \mathrm{L})$ or more aluminum, $5 \mu \mathrm{g} / \mathrm{L}$ or more arsenic, or $10 \mu \mathrm{g} / \mathrm{L}$ or more chromium. 


\section{Detections of Organic Compounds}

Samples collected from the 50 wells shown on figure $9 \mathrm{a}$ were analyzed for VOCs (table 3 ), and samples from 33 of these wells (fig. 9b) were sampled for ordnance and semi-volatile organic compounds (table 4) in addition to VOCs. No semi-volatile organic compounds or ordnance compounds were detected in any of the wells included in this study; VOCs were detected in two wells. A small concentration of toluene was found in a well located just west of the base and open to QA1 (fig. 9c). The well (26N/01W-25L02, see fig. 3), which is 128 feet deep, had been in operation for only a week when it was sampled. The toluene concentration measured in the well was $0.4 \mu \mathrm{g} / \mathrm{L}$; the MCL for toluene is $1,000 \mu \mathrm{g} / \mathrm{L}$. Toluene, which is found in fuels (including gasoline), was probably introduced during the drilling of the well. A concentration of trichloroethylene (TCE) exceeding the MCL was found in a well (25N/01E-17N01, see fig. 3) open to Qva and located near Strawberry Creek (figs. 1 and 9d). The well, which is 71 feet deep, is located near an old dump that probably contaminated the local ground water; the well also had very high specific conductance and dissolved solids compared to the rest of the wells in the study area. TCE is an industrial solvent commonly used in dry cleaning. The concentration of TCE measured in the well was $5.3 \mu \mathrm{g} / \mathrm{L}$; the MCL for TCE is $5.0 \mu \mathrm{g} / \mathrm{L}$. The other VOCs detected in this well were cis-1,2-dichloroethylene $(2.0 \mu \mathrm{g} / \mathrm{L} ; \mathrm{MCL} 70 \mu \mathrm{g} / \mathrm{L}) ; 1,1$-dichloroethane $(0.7 \mu \mathrm{g} / \mathrm{L}$; no MCL); and dichlorodifluoromethane $(0.8 \mu \mathrm{g} / \mathrm{L}$; no MCL). (Data for these two wells were not included in calculating percentiles for ambient background levels or for the boxplots in fig. 6 .)

\section{Ambient Background Levels of Inorganic Constituents}

The median (50th percentile) and 90th percentile concentrations of 31 inorganic constituents are listed in tables 7 and 8. (Background levels for cadmium, copper, silver, and zinc could not be determined because of suspected field contamination of samples.) Some concentrations are reported as less than $(<)$ a given value where the value given is the reporting level of the analytical method (listed in table 1 or 2). In general, the highest ambient background levels for the study area are in QC1 and QC1pi. This is probably because water that has been in the ground for a longer time (as is expected for confining units) has had the opportunity to dissolve more minerals than water with a shorter residence time.

The only drinking water standards exceeded by ambient background levels were SMCLs for iron and manganese: the 90th percentile values for manganese are above the SMCL for all of the units, and the 90th percentile values for iron are above the SMCL in QC1 and QC1pi. The 90th percentile values for arsenic in QC1pi, QA1, and for the entire study area are above $5 \mu \mathrm{g} / \mathrm{L}$, the Model Toxics Control Act Method A value for protecting drinking water (Washington State Department of Ecology, 1996), but below the MCL of $50 \mu \mathrm{g} / \mathrm{L}$ for arsenic. 


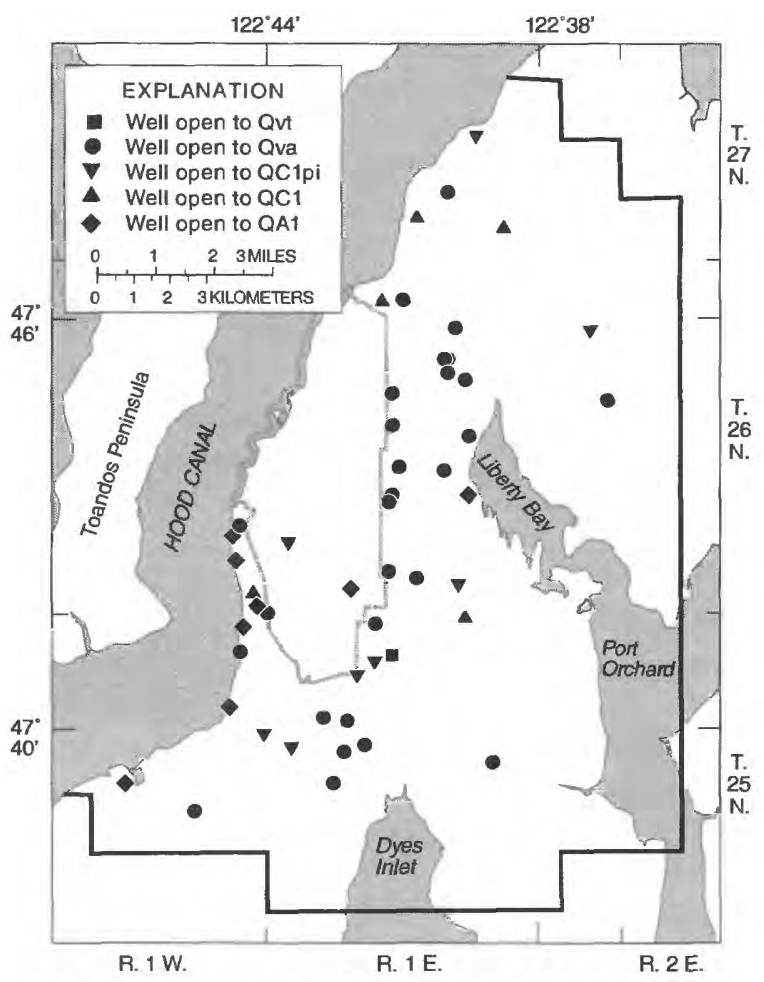

(a) Wells sampled for compounds listed in table 3 .

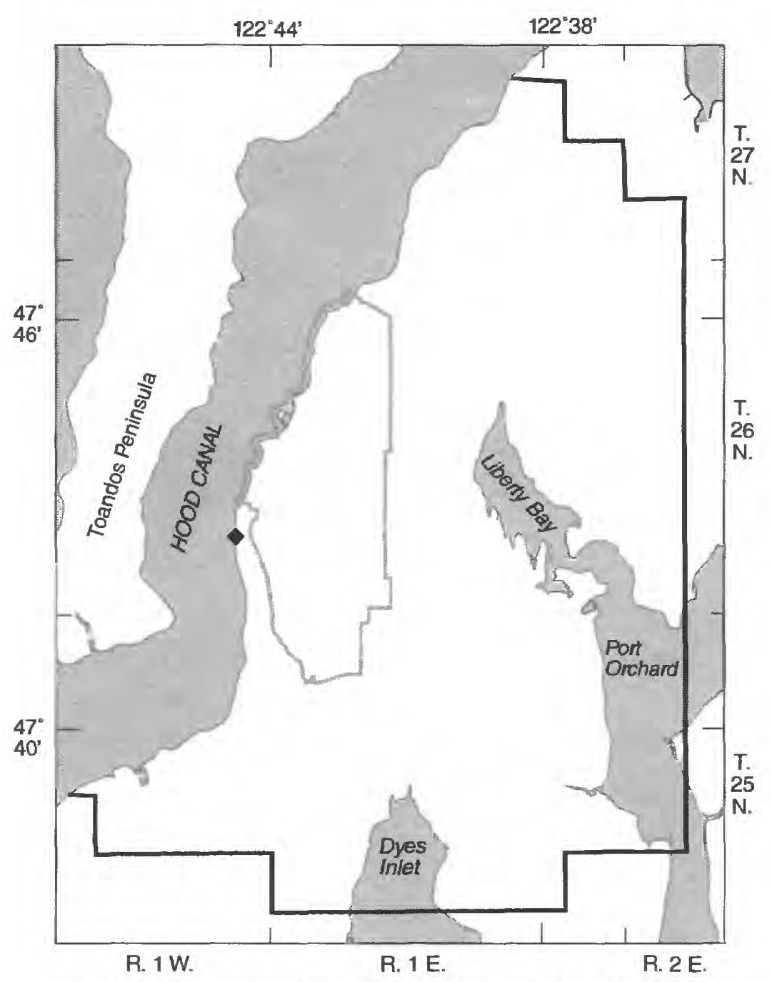

(c) Well with detected concentration of 0.4 micrograms per liter $(\mu \mathrm{g} / \mathrm{L})$ of toluene.

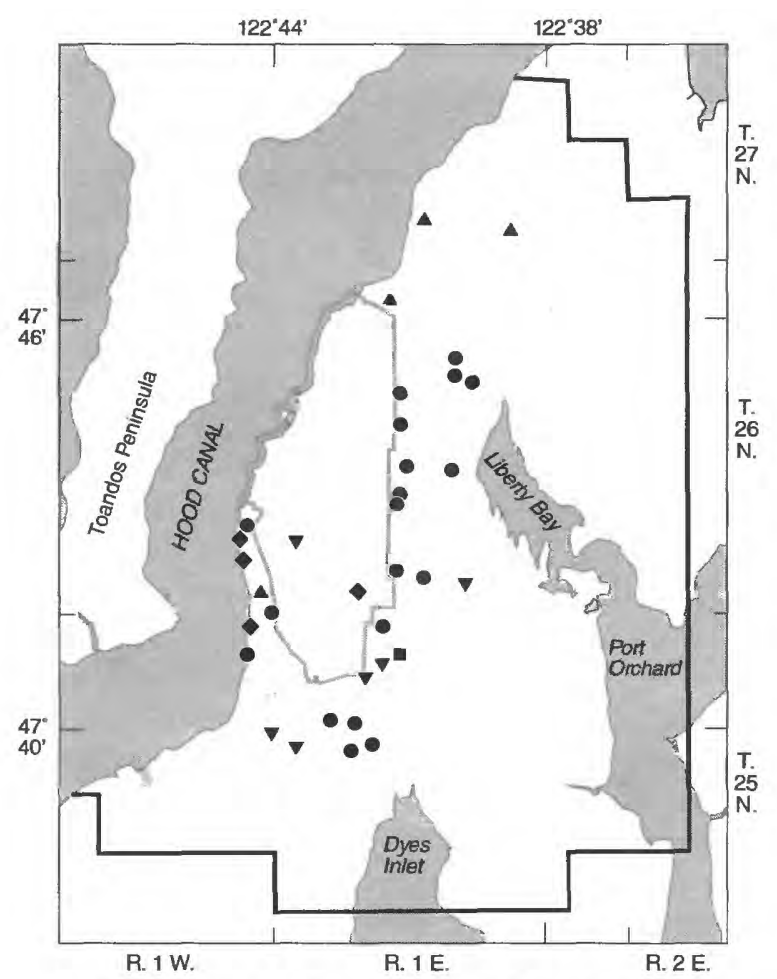

(b) Wells sampled for compounds listed in table 4.

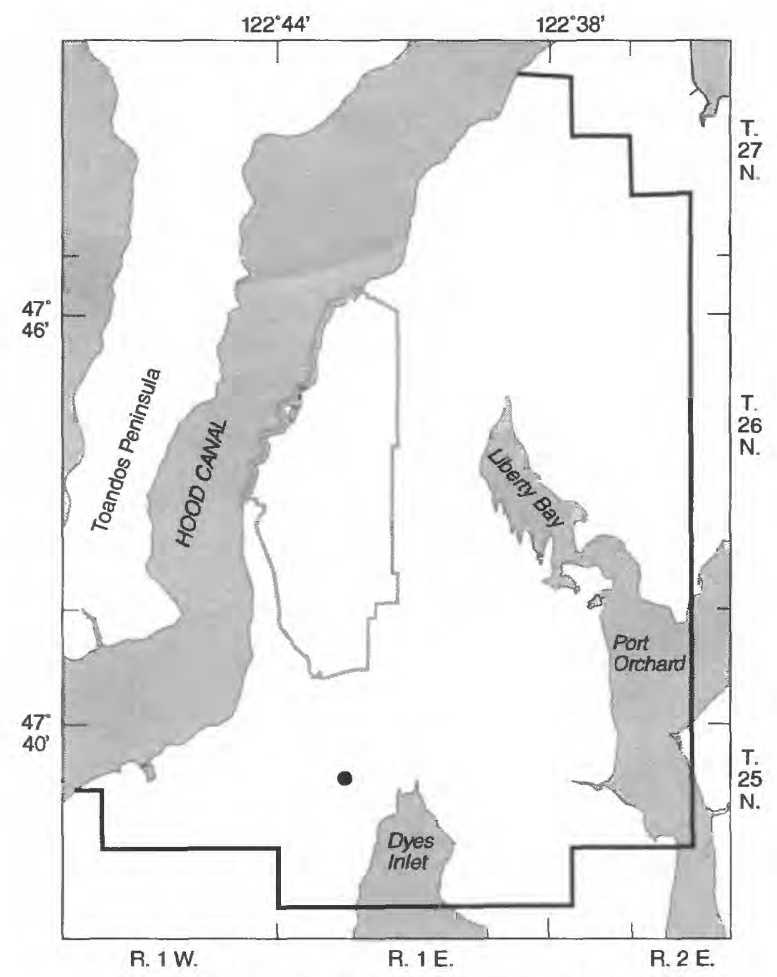

(d) Well with detected concentration of 5.3 micrograms per liter $(\mu \mathrm{g} / \mathrm{L})$ of trichloroethylene.

Figure 9. Wells sampled for organic compounds, and locations of wells with detected concentrations of organic compounds. The maximum contaminant levels for toluene and trichloroethylene are 1,000 micrograms per liter $(\mu \mathrm{g} / \mathrm{L})$ and $5.0 \mu \mathrm{g} / \mathrm{L}$. 
Table 7.--Median (50th percentile) concentrations of selected inorganic constituents

[A minimum of ten samples is needed to determine a median concentration; only three samples were collected from the Vashon till confining unit. Qva, Vashon aquifer; QC1 pi, Permeable interbeds; QC1, Upper confining unit; QA1, Sea-level aquifer; $\mu \mathrm{g} / \mathrm{L}$, micrograms per liter; mg/L, milligrams per liter; --, insufficient data; $\mathrm{N}$, nitrogen; $\mathrm{P}$, phosphorus]

\begin{tabular}{|c|c|c|c|c|c|}
\hline \multirow[b]{2}{*}{ Constituent, reporting units } & \multicolumn{4}{|c|}{ Hydrogeologic unit } & \multirow{2}{*}{$\begin{array}{l}\text { Study } \\
\text { area }\end{array}$} \\
\hline & Qva & QC1pi & QC1 & QA1 & \\
\hline Aluminum, $\mu \mathrm{g} / \mathrm{L}$ & $<10$ & $<10$ & -- & $<10$ & $<10$ \\
\hline Ammonia, $\mathrm{mg} / \mathrm{L}$ as $\mathrm{N}$ & $<0.015$ & 0.040 & 0.045 & 0.080 & $<0.015$ \\
\hline Arsenic, $\mu \mathrm{g} / \mathrm{L}$ & $<1$ & 2 & -- & $<1$ & 1 \\
\hline Barium, $\mu \mathrm{g} / \mathrm{L}$ & 3 & 5 & -- & 4 & 3 \\
\hline Beryllium, $\mu \mathrm{g} / \mathrm{L}$ & $<0.5$ & $<0.5$ & -- & $<0.5$ & $<0.5$ \\
\hline Boron, $\mu \mathrm{g} / \mathrm{L}$ & $<10$ & 10 & -- & 10 & $<10$ \\
\hline Bromide, mg/L & 0.01 & 0.01 & 0.02 & 0.02 & 0.02 \\
\hline Calcium, mg/L & 11 & 14 & 15 & 15 & 13 \\
\hline Chloride, $\mathrm{mg} / \mathrm{L}$ & 2.5 & 2.1 & 2.3 & 1.9 & 2.2 \\
\hline Chromium, $\mu \mathrm{g} / \mathrm{L}$ & $<5$ & $<5$ & -- & $<5$ & $<5$ \\
\hline Cobalt, $\mu \mathrm{g} / \mathrm{L}$ & $<3$ & $<3$ & -- & $<3$ & $<3$ \\
\hline Fluoride, mg/L & $<0.1$ & $<0.1$ & $<0.1$ & $<0.1$ & $<0.1$ \\
\hline Iodide, $\mu \mathrm{g} / \mathrm{L}$ & 1 & 1 & -- & 1 & 1 \\
\hline Iron, $\mu \mathrm{g} / \mathrm{L}$ & 10 & 39 & 42 & 14 & 14 \\
\hline Lead, $\mu \mathrm{g} / \mathrm{L}$ & $<1$ & $<1$ & -- & $<1$ & $<1$ \\
\hline Lithium, $\mu \mathrm{g} / \mathrm{L}$ & $<4$ & $<4$ & -- & $<4$ & $<4$ \\
\hline Magnesium, mg/L & 8.0 & 7.8 & 7.8 & 6.8 & 7.6 \\
\hline Manganese, $\mu \mathrm{g} / \mathrm{L}$ & 1.0 & 38 & 43 & 14 & 3.5 \\
\hline Mercury, $\mu \mathrm{g} / \mathrm{L}$ & $<0.1$ & $<0.1$ & -- & $<0.1$ & $<0.1$ \\
\hline Molybdenum, $\mu \mathrm{g} / \mathrm{L}$ & $<10$ & $<10$ & -- & $<10$ & $<10$ \\
\hline Nickel, $\mu \mathrm{g} / \mathrm{L}$ & $<10$ & $<10$ & -- & $<10$ & $<10$ \\
\hline Nitrate plus nitrite, $\mathrm{mg} / \mathrm{L}$ as $\mathrm{N}$ & 0.19 & $<0.05$ & $<0.05$ & $<0.05$ & 0.06 \\
\hline Nitrite, $\mathrm{mg} / \mathrm{L}$ as $\mathrm{N}$ & $<0.01$ & $<0.01$ & $<0.01$ & $<0.01$ & $<0.01$ \\
\hline Orthophosphate, $\mathrm{mg} / \mathrm{L}$ as $\mathrm{P}$ & 0.04 & 0.09 & 0.09 & 0.11 & 0.065 \\
\hline Potassium, mg/L & 0.8 & 1.3 & 1.1 & 1.4 & 1.0 \\
\hline Selenium, $\mu \mathrm{g} / \mathrm{L}$ & $<1$ & $<1$ & -- & $<1$ & $<1$ \\
\hline Silica, mg/L & 28 & 30 & 31 & 26 & 29 \\
\hline Sodium, mg/L & 4.6 & 5.2 & 6.1 & 5.5 & 4.9 \\
\hline Strontium, $\mu \mathrm{g} / \mathrm{L}$ & 52 & 56 & -- & 61 & 56 \\
\hline Sulfate, $\mathrm{mg} / \mathrm{L}$ & 3.9 & 1.6 & 3.2 & 1.8 & 2.5 \\
\hline Vanadium, $\mu \mathrm{g} / \mathrm{L}$ & $<6$ & $<6$ & -- & $<6$ & $<6$ \\
\hline
\end{tabular}


Table 8.--90th percentile concentrations of selected inorganic constituents

[A minimum of ten samples is needed to determine a median concentration; only three samples were collected from the Vashon till confining unit. Numbers in bold letters exceed drinking-water standards. Qva, Vashon aquifer; QC1 pi, Permeable interbeds; QC1, Upper confining unit; QA1, Sea-level aquifer; $\mu \mathrm{g} / \mathrm{L}$, micrograms per liter; mg/L, milligrams per liter; --, insufficient data; N, nitrogen; $\mathrm{P}$, phosphorus]

\begin{tabular}{|c|c|c|c|c|c|}
\hline \multirow[b]{2}{*}{ Constituent, reporting units } & \multicolumn{4}{|c|}{ Hydrogeologic unit } & \multirow{2}{*}{$\begin{array}{l}\text { Study } \\
\text { area }\end{array}$} \\
\hline & Qva & QC1pi & $\mathrm{QCl}$ & QA1 & \\
\hline Aluminum, $\mu \mathrm{g} / \mathrm{L}$ & 10 & 10 & -- & 17 & 10 \\
\hline Ammonia, $\mathrm{mg} / \mathrm{L}$ as $\mathrm{N}$ & 0.07 & 1.6 & 0.89 & 0.36 & 0.51 \\
\hline Arsenic, $\mu \mathrm{g} / \mathrm{L}$ & 4 & 10 & -- & 12 & 6 \\
\hline Barium, $\mu \mathrm{g} / \mathrm{L}$ & 6 & 14 & -- & 11 & 11 \\
\hline Beryllium, $\mu \mathrm{g} / \mathrm{L}$ & $<0.5$ & $<0.5$ & -- & $<0.5$ & $<0.5$ \\
\hline Boron, $\mu \mathrm{g} / \mathrm{L}$ & $<10$ & 30 & -- & 62 & 20 \\
\hline Bromide, $\mathrm{mg} / \mathrm{L}$ & 0.03 & 0.02 & 0.02 & 0.03 & 0.02 \\
\hline Calcium, mg/L & 17 & 24 & 22 & 20 & 20 \\
\hline Chloride, $\mathrm{mg} / \mathrm{L}$ & 4.7 & 3.3 & 6.1 & 3.1 & 3.7 \\
\hline Chromium, $\mu \mathrm{g} / \mathrm{L}$ & 7 & $<5$ & -- & 5 & 7 \\
\hline Cobalt, $\mu g / L$ & $<3$ & 10 & -- & 3 & $<3$ \\
\hline Fluoride, mg/L & $<0.1$ & 0.1 & 0.1 & 0.1 & 0.1 \\
\hline Iodide, $\mu \mathrm{g} / \mathrm{L}$ & 2 & 2 & -- & 2 & 2 \\
\hline Iron, $\mu \mathrm{g} / \mathrm{L}$ & 67 & 875 & 996 & 60 & 224 \\
\hline Lead, $\mu \mathrm{g} / \mathrm{L}, \mathrm{mg} / \mathrm{L}$ & $<1$ & $<1$ & -- & $<1$ & $<1$ \\
\hline Lithium, $\mu \mathrm{g} / \mathrm{L}$ & 4 & $<4$ & -- & 8 & $<4$ \\
\hline Magnesium, mg/L & 12 & 12 & 14 & 9 & 12 \\
\hline Manganese, $\mu \mathrm{g} / \mathrm{L}$ & 60 & 275 & 355 & 89 & 110 \\
\hline Mercury, $\mu \mathrm{g} / \mathrm{L}$ & $<0.1$ & $<0.1$ & -- & $<0.1$ & $<0.1$ \\
\hline Molybdenum, $\mu \mathrm{g} / \mathrm{L}$ & $<10$ & 10 & -- & $<10$ & $<10$ \\
\hline Nickel, $\mu \mathrm{g} / \mathrm{L}$ & 10 & $<10$ & -- & $<10$ & $<10$ \\
\hline Nitrate plus nitrite, $\mathrm{mg} / \mathrm{L}$ as $\mathrm{N}$ & 2.0 & 0.46 & 1.3 & 0.74 & 1.2 \\
\hline Nitrite, $\mathrm{mg} / \mathrm{L}$ as $\mathrm{N}$ & 0.02 & 0.02 & 0.02 & 0.02 & 0.02 \\
\hline Orthophosphate, $\mathrm{mg} / \mathrm{L}$ as $\mathrm{P}$ & 0.10 & 0.91 & 0.54 & 0.30 & 0.33 \\
\hline Potassium, mg/L & 1.7 & 2.7 & 4.2 & 3.2 & 2.5 \\
\hline Selenium, $\mu \mathrm{g} / \mathrm{L}$ & $<1$ & $<1$ & -- & $<1$ & $<1$ \\
\hline Silica, $\mathrm{mg} / \mathrm{L}$ & 34 & 43 & 37 & 36 & 36 \\
\hline Sodium, mg/L & 5.8 & 9.3 & 19 & 14 & 8.0 \\
\hline Strontium, $\mu \mathrm{g} / \mathrm{L}$ & 80 & 140 & -- & 142 & 110 \\
\hline Sulfate, $\mathrm{mg} / \mathrm{L}$ & 6.8 & 6.7 & 9.7 & 4.2 & 6.3 \\
\hline Vanadium, $\mu \mathrm{g} / \mathrm{L}$ & 8 & $<6$ & -- & 7 & 7 \\
\hline
\end{tabular}




\section{SUMMARY AND CONCLUSIONS}

Naval Submarine Base Bangor is a 6,785-acre military installation located in northwest Kitsap County, Washington. Activities on the base since 1944 have resulted in contamination of soils and shallow ground water at many sites on the base. Investigations to date have focused on assessing contamination at individual sites, and the U.S. Navy needs additional information about ambient ground-water quality to effectively plan and manage cleanup activities on the base.

In March and April 1995, 136 water-supply wells were sampled to characterize the ambient water quality in the vicinity of the base. Most of the 136 wells sampled for water quality were located around the boundary of the base. Seven wells on the base were sampled, and additional wells were located throughout the study area, which is about nine times the land area of the base. The wells ranged in depth from 43 to 538 feet. The hydrogeologic units investigated during this study (in order from shallow to deep) were the Vashon till confining unit (Qvt, 3 wells); the Vashon aquifer (Qva, 54 wells); the Upper confining unit (QC1, 16 wells); the Permeable interbeds within QC1 (QC1pi, 34 wells); and the Sea-level aquifer (QA1, 29 wells). All of the wells were sampled for common ions and nutrients, 82 of the wells were sampled for trace elements, 50 wells were sampled for volatile organic compounds (VOCs), and 33 wells were sampled for ordnance and semi-volatile organic compounds.

Man-made organic compounds were detected in only two wells. A small amount of toluene $(0.4 \mu \mathrm{g} / \mathrm{l}$, compared with the MCL of $1,000 \mu \mathrm{g} / \mathrm{L}$ ) probably was introduced during the construction of a 128-foot-deep well, which was new at the time of sampling. A trichloroethylene concentration of $5.3 \mu \mathrm{g} / \mathrm{L}$ (above the MCL of $5.0 \mu \mathrm{g} / \mathrm{L}$ ) and smaller amounts of three other VOCs detected in a 43-foot-deep well probably were due to contamination from a local dump. This well also had very high specific conductance and dissolved solids compared with the rest of the wells sampled. The results from the sampling of these two wells were not included in the determination of ambient background levels.

Ambient background levels of inorganic constituents in each unit were determined by nonparametric calculation of the 50th and 90th percentile values to represent the common average values and common upper values of the constituents. No ambient background levels were determined for Qvt because not enough samples were collected from wells open to the unit. Ambient background levels generally were highest in $\mathrm{QCl}$ and QCl pi. The 90th percentile values for manganese are above the SMCL for all of the units; and the 90th percentile values for iron are above the SMCL in QC1 and QC1pi. The 90th percentile values for arsenic are above $5 \mu \mathrm{g} / \mathrm{L}$ for QC1pi, QA1, and for the entire study area (the MCL is $50 \mu \mathrm{g} / \mathrm{L}$ ). Mercury and selenium were not detected in any of the samples, and lead was detected only in two samples.

High concentrations of iron and manganese generally occur in wells with concentrations of dissolved oxygen less than $1 \mathrm{mg} / \mathrm{L}$ or dissolved organic carbon greater than $1 \mathrm{mg} / \mathrm{L}$ or both. The median dissolved oxygen concentration is generally lower in the deeper units, while the median $\mathrm{pH}$ increases; the recommended $\mathrm{pH}$ range of 6.5 to 8.5 standard units was exceeded in 9 wells.

The U.S. Navy may require additional information about ambient water quality in Qvt. This is the shallowest hydrogeologic unit investigated in this study, and only three of the selected wells are open to this unit. The trace element antimony was not included in the laboratory analyses performed for this study, and it may benefit the U.S. Navy to sample selected wells in one or more hydrogeologic units for antimony; a smaller set of wells can be selected based on the findings of this study and the study by Kahle (in press).

\section{REFERENCES CITED}

Dion, N.P., and Sumioka, S.S., 1984, Seawater intrusion into coastal aquifers in Washington, 1978: Washington Department of Ecology Water-Supply Bulletin 56, $13 \mathrm{p}$.

Fishman, M.J., ed., 1993, Methods of analysis by the U.S. Geological Survey National Water Quality Laboratory-Determination of inorganic and organic constituents in water and fluvial sediments: U.S. Geological Survey Open-File Report 93-125, 217 p.

Friedman, L.C. and Erdman, D.E., 1982, Quality assurance practices for the chemical and biological analyses of water and fluvial sediments: Techniques of Water-Resources Investigations of the U.S. Geological Survey, Book 5, Chapter A6, 181 p. 
Hansen, A.J. Jr., and Bolke, E.L., 1980, Ground-water availability on the Kitsap peninsula, Washington: U.S. Geological Survey Water-Resources Investigations Open-File Report 80-1186, 65 p.

Hart-Crowser, Inc., 1988, Current situation report, site A, Naval Submarine Base, Bangor, Washington: Seattle, Hart-Crowser, Inc., 2 v.

1989, Current situation report, sites C, D, E, F, 5, 6, 11, 12, 24, and 25, SUBASE Bangor, Washington: Seattle, Hart-Crowser, Inc., 2 v.

Hem, J.D., 1985, Study and interpretation of the chemical characteristics of natural water: U.S. Geological Survey Water-Supply Paper 2254, 263 p.

Helsel, D.R. and Hirsch, R.M., 1992, Statistical methods in water resources: Amsterdam, Elsevier Science Publishers, $522 \mathrm{p}$.

Jones, M.A., 1996, Thickness of unconsolidated deposits in the Puget Sound Lowland, Washington and British Columbia: U.S. Geological Survey Water Resources Investigation Report 94-4133, 1 pl.

Kahle, S.C., in press, Hydrogeology of Naval Submarine Base Bangor and vicinity, Kitsap County, Washington: U.S. Geological Survey Water-Resources Investigations Report 97-4060.

Kitsap County Ground Water Advisory Committee, Economic and Engineering Services, Inc., Hart-Crowser, Inc., Pacific Groundwater Group, and Robinson and Noble, Inc., 1991, Kitsap County ground water management plan: Olympia, Economic and Engineering Services, Inc., 2 v.

Koterba, M.T., Wilde, F.D., and Lapham, W.W., 1995 , Ground-water data-collection protocols and procedures for the National Water-Quality Assessment Program-Collection and documentation of water-quality samples and related data: U.S. Geological Survey Open-File Report 95-399, 113 p.
Lindley, C.E., Burkhardt M.R., and DeRusseau, S.N., 1994, Methods of analysis by the U.S. Geological Survey National Water Quality LaboratoryExtraction of nitroaromatic compounds from water by polystyrene divinylbenzene cartridge and determination by high-performance liquid chromatography: U.S. Geological Survey Open-File Report 94-62, 15 p.

Parametrix, Inc., 1994, Comprehensive water system plan, Naval Submarine Base, Bangor: Bremerton, Wash., Parametrix, Inc., approximately 500 p.

Piper, A.M., 1944, A graphic procedure in the geochemical interpretation of water analyses: American Geophysical Union Transactions, v. 25, p. 914-923.

Pritt, J.W., and Raese, J.W., eds., 1995, Quality assurance/ quality control manual, National Water Quality Laboratory: U.S. Geological Survey Open-File Report 95-443, 35 p.

U.S. Bureau of the Census, 1992, 1990 Census of population and housing, in Summary Tape File $1 \mathrm{~A}$ on CD-ROM, Washington D.C.

U.S. Environmental Protection Agency, 1988, Methods for the determination of organic compounds in drinking water: U.S. Environmental Protection Agency, Office of Water, EPA 600-4-88-039, 324 p.

1994a, Consolidated rule summary for the chemical phases: U.S. Environmental Protection Agency, Office of Water, EPA 812-S-94-001, 34 p.

1994b, Drinking water regulations and health advisories: U.S. Environmental Protection Agency, Office of Water, EPA 822-R-94-001, 11 p.

Washington State Department of Ecology, 1992, Statistical Guidance for Ecology Site Managers: Olympia, Wash., Washington State Department of Ecology, Toxics Cleanup Program, 71 p., appendices. 
1996, Model Toxics Control Act cleanup levels and risk calculations (CLARC II) update: Olympia, Wash., Washington State Department of Ecology, 94-145, 17 p., appendices.

Washington State Department of Health, 1994, Group A public water systems, chapter 246-290 WAC: Olympia, Wash., Washington State Department of Health, Division of Drinking Water, 127 p.

1995, Group B public water systems, chapter 246-291 WAC: Olympia, Wash., Washington State Department of Health, Division of Drinking Water, $29 \mathrm{p}$.

White, A.F., Peterson, M.L., and Solbau, R.D., 1992 , Measurement and interpretation of low levels of dissolved oxygen in ground water: Ground Water, v. 28 , no. 4 , p. $584-590$.

\section{APPENDIX A}

\section{Summary of Existing Water-Quality Data for the Deep Aquifer}

Previously existing water-quality data were obtained for five wells in the study area open to the Deep aquifer (QA2). Three wells operated by the Silverdale Water District and located south of the base (the "Westwind," "Hess," and "Wixson" wells); one well located in the southeast part of Naval Submarine Base Bangor ("TH1," or test hole \#1); and one well operated by Public Utility District No. 1 of Kitsap County ("Vinland View \#2"), located about one mile northwest of the base. All of these wells have been sampled for inorganic constituents including sodium, chloride, iron, manganese, nitrate, nitrite, silver, and selenium; the remainder of the constituents sampled varied for TH1, Vinland View \#2, and the Silverdale wells.

Results provided to the U.S. Geological Survey for Vinland View \#2 were for samples collected in December 1993, with additional chloride samples in April 1994 (Marty Sebren and Jim Le Cuyer, Public Utility District No. 1 of Kitsap County, written commun., May 1995). TH1 was sampled by the U.S. Geological Survey in June 1994. The results for the Silverdale wells were for samples collected in December 1995 (Eric Pickard, Silverdale Water District, written commun., March 1996). All samples were collected before any water treatment.

Chloride concentrations in QA2 are of interest because high concentrations indicate potential intrusion of salt water into the aquifer. Chloride concentrations in the five wells were low: the highest detected concentration was $1.5 \mathrm{mg} / \mathrm{L}$ (the reporting limit was $1 \mathrm{mg} / \mathrm{L}$ for all but one sample, from Vinland View \#2, which had a reporting limit of $5 \mathrm{mg} / \mathrm{L}$ ). The specific conductance of the QA2 ground water ranged from 91 to $93 \mu \mathrm{S} / \mathrm{cm}$ in the Silverdale wells, $144 \mu \mathrm{S} / \mathrm{cm}$ in Vinland View \#2, and $149 \mu \mathrm{S} / \mathrm{cm}$ in TH1. Sodium concentrations ranged from 3 to $4.6 \mathrm{mg} / \mathrm{L}$ in the five wells. No other constituents listed above were detected in the Silverdale wells; only iron and manganese were detected in TH1; and nitrate, iron, and manganese were detected in Vinland View \#2, with the manganese concentration $(63 \mu \mathrm{g} / \mathrm{L})$ exceeding the SMCL. 
Appendix B.-- Wells sampled for ambient water quality March and April 1995

[Qvt, Vashon till confining unit; Qva; Vashon aquifer; QC1, upper confining unit; QC1pi, permeable interbeds; QA I, Sea-level aquifer; 1, sampled for constituents listed in table 1; 2, sampled for constituents listed in table 2; 3, sampled for constituents listed in table 3; 4, sampled for constituents listed in table 4]

\begin{tabular}{|c|c|c|c|c|c|c|c|}
\hline $\begin{array}{l}\text { Local number } \\
\text { of the well }\end{array}$ & $\begin{array}{l}\text { Hydro- } \\
\text { geologic } \\
\text { unit }\end{array}$ & $\begin{array}{l}\text { Depth } \\
\text { of well } \\
\text { (feet) }\end{array}$ & $\begin{array}{l}\text { Sample } \\
\text { code }\end{array}$ & $\begin{array}{l}\text { Local number } \\
\text { of the well }\end{array}$ & $\begin{array}{l}\text { Hydro- } \\
\text { geologic } \\
\text { unit }\end{array}$ & $\begin{array}{l}\text { Depth } \\
\text { of well } \\
\text { (feet) }\end{array}$ & $\begin{array}{l}\text { Sample } \\
\text { code }\end{array}$ \\
\hline 25N/01E-03K01 & Qva & 56.6 & 1 & $25 \mathrm{~N} / 01 \mathrm{~W}-01 \mathrm{G} 05$ & QA1 & 178 & $1,2,3$ \\
\hline $25 \mathrm{~N} / 01 \mathrm{E}-04 \mathrm{C} 01$ & QA1 & 289 & 1 & $25 \mathrm{~N} / 01 \mathrm{~W}-01 \mathrm{~K} 03$ & Qva & 71 & $1,2,3,4$ \\
\hline $25 \mathrm{~N} / 01 \mathrm{E}-04 \mathrm{M} 03$ & Qvt & 60 & $1,2,3,4$ & $25 \mathrm{~N} / 01 \mathrm{~W}-12 \mathrm{~J} 01$ & QC1pi & 360 & 1,2 \\
\hline $25 \mathrm{~N} / 01 \mathrm{E}-05 \mathrm{~A} 04$ & Qva & 98.4 & & $25 \mathrm{~N} / 01 \mathrm{~W}-12 \mathrm{~K} 04$ & QC1pi & 204 & 1,2 \\
\hline $25 \mathrm{~N} / 01 \mathrm{E}-05 \mathrm{Q} 01$ & QC1pi & 157 & $1,2,3,4$ & $25 \mathrm{~N} / 01 \mathrm{~W}-12 \mathrm{~L} 02$ & QA1 & 86 & $1,2,3$ \\
\hline 25N/01E-05R02 & QC1pi & 179 & $1,2,3$ & $25 \mathrm{~N} / 01 \mathrm{~W}-12 \mathrm{R} 01$ & QC1pi & 362 & $1,2,3,4$ \\
\hline $25 \mathrm{~N} / 01 \mathrm{E}-06 \mathrm{E} 01$ & QA1 & 312 & 1 & $25 \mathrm{~N} / 01 \mathrm{~W}-12 \mathrm{R} 02$ & Qva & 100 & \\
\hline 25N/01E-06L02 & QA1 & 384 & 1 & 25N/01W-13L01 & QA1 & 411 & 1 \\
\hline $25 \mathrm{~N} / 01 \mathrm{E}-07 \mathrm{C} 02$ & QA1 & 371 & 1,2 & $25 \mathrm{~N} / 01 \mathrm{~W}-13 \mathrm{R} 02$ & QC1 & 160 & 1,2 \\
\hline 25N/01E-07J01 & Qva & 83 & $1,2,3$ & $25 \mathrm{~N} / 01 \mathrm{~W}-15 \mathrm{~L} 01$ & QA1 & 132 & 1 \\
\hline 25N/01E-07J02 & $\mathrm{QC} 1_{1}$ & 260 & 1,2 & $\mathrm{~N} / 01 \mathrm{~W}-15 \mathrm{~N} 02$ & $c$ & 270 & 1 \\
\hline $25 \mathrm{~N} / 01 \mathrm{E}-07 \mathrm{~K} 01$ & Qva & 147 & 1,2 & $5 \mathrm{Q} 03$ & QA1 & 173 & 1,2 \\
\hline $25 \mathrm{~N} / 01 \mathrm{E}-07 \mathrm{~N} 02 \mathrm{D} 1$ & QC1pi & 358 & 1,2 & $25 \mathrm{~N} / 01 \mathrm{~W}-23 \mathrm{G} 01$ & Qva & 182 & $1,2,3$ \\
\hline 25N/01E-07P02 & QC1 pi & 297 & 1,2 & $25 \mathrm{~N} / 01 \mathrm{~W}-23 \mathrm{~K} 04$ & QC1pi & 255 & 1 \\
\hline 25N/01E-07Q03 & QC1pi & 252 & 1,2 & $25 \mathrm{~N} / 01 \mathrm{~W}-24 \mathrm{~B} 02$ & QC1pi & 311 & 1 \\
\hline $25 \mathrm{~N} / 01 \mathrm{E}-08 \mathrm{~J} 02$ & QC1pi & 168 & 1,2 & $25 \mathrm{~N} / 01 \mathrm{~W}$ & & 278 & 1 \\
\hline $25 \mathrm{~N} / 01 \mathrm{E}$ & Qva & 113 & $1,2,3,4$ & $1 \mathrm{~W}-24 \mathrm{~N} 02$ & QC1 & 189 & 1 \\
\hline 25N/01E-08L04 & Qva & 70 & 1,2 & 26N/01E-01D01 & QC1pi & 315 & 1,2 \\
\hline 25N/01E-08Q03 & QC1pi & 300 & 1,2 & 26N/01E-01N01 & QC1pi & 284 & 1 \\
\hline 25N/01E-09N02 & QC1pi & 84 & 1,2 & $26 \mathrm{~N} / 01 \mathrm{E}-02 \mathrm{G} 02$ & Qva & 43 & 1 \\
\hline $25 \Lambda$ & & 342 & 1 & 11 & Q & 304 & 1 \\
\hline $25 \mathrm{~N} / 01 \mathrm{E}-12 \mathrm{~N} 01$ & $\mathrm{QC1}$ & 267 & 1 & 26N/01E-02K02 & QA1 & 277 & 1 \\
\hline $25 \mathrm{~N} / 01 \mathrm{E}-13 \mathrm{~L} 02$ & Qvt & 89 & 1 & 26N/01E-02L05 & QA1 & 312 & 1 \\
\hline $25 \mathrm{~N} / 01 \mathrm{E}-15 \mathrm{~J} 03$ & Qva & 152 & 1,2 & 26N/01E-03F02 & $\mathrm{QC} 1$ & 331 & 1 \\
\hline $25 \mathrm{~N} / 01 \mathrm{E}-17 \mathrm{~B} 01$ & Qva & 90 & $1,2,3,4$ & 26N/01E-03N02 & Qva & 117 & 1 \\
\hline $25 \mathrm{~N} / 0$ & Qva & 98 & $1,2,3,4$ & 3 & Q & 28 & 1 \\
\hline $25 \mathrm{~N} / 01 \mathrm{E}-17 \mathrm{G} 01$ & QC1pi & 193 & 1 & 01 & QClpi & 271 & 1 \\
\hline $25 \mathrm{~N} / 01 \mathrm{E}-17 \mathrm{~N} 01$ & Qva & 71 & 1,2 & 26N/01E-04L01 & Qva & 104 & $1,2,3$ \\
\hline $25 \mathrm{~N} / 01 \mathrm{E}-18 \mathrm{C} 02$ & QC1pi & 195 & 1,2 & 26N/01E-05J02 & $\mathrm{QC} 1$ & 95 & $1,2,3,4$ \\
\hline $25 \mathrm{~N} / 01 \mathrm{E}-18 \mathrm{~L} 01$ & QC1pi & 341 & 1 & $26 \mathrm{~N} / 01 \mathrm{E}-09 \mathrm{C} 02$ & QAI & 538 & 1,2 \\
\hline $25 \Gamma$ & Q & 23 & 1 & 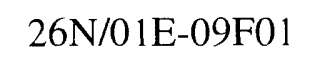 & pi & 307 & 1 \\
\hline D01 & QC1 & 108 & 1 & 26N/01E-09G03 & Qva & 126 & $1,2,3,4$ \\
\hline 25N/01E-27R01 & QC1pi & 156 & 1 & 26N/01E-09K02 & Qva & 108 & $1,2,3,4$ \\
\hline $25 \mathrm{~N} / 01 \mathrm{E}-30 \mathrm{D} 03$ & Qva & 410 & 1 & 26N/01E-10D01 & Qva & 116 & $1,2,3$ \\
\hline $25 \mathrm{~N} / 01 \mathrm{~W}-01 \mathrm{~B} 02$ & QA1 & 119 & $1,2,3,4$ & $26 \mathrm{~N} / 01 \mathrm{E}-10 \mathrm{H} 02$ & Qva & 126 & 1,2 \\
\hline
\end{tabular}




\section{Appendix B.-- continued}

[Qvt, Vashon till confining unit; Qva; Vashon aquifer; QC1, upper confining unit; QC1pi, permeable interbeds; QA1, Sea-level aquifer; 1, sampled for constituents listed in table 1;2, sampled for constituents listed in table $2 ; 3$, sampled for constituents listed in table $3 ; 4$, sampled for constituents listed in table 4]

\begin{tabular}{|c|c|c|c|c|c|c|c|}
\hline $\begin{array}{l}\text { Local number } \\
\text { of the well }\end{array}$ & $\begin{array}{l}\text { Hydro- } \\
\text { geologic } \\
\text { unit }\end{array}$ & $\begin{array}{l}\text { Depth } \\
\text { of well } \\
\text { (feet) }\end{array}$ & $\begin{array}{l}\text { Sample } \\
\text { code }\end{array}$ & $\begin{array}{l}\text { Local number } \\
\text { of the well }\end{array}$ & $\begin{array}{l}\text { Hydro- } \\
\text { geologic } \\
\text { unit }\end{array}$ & $\begin{array}{l}\text { Depth } \\
\text { of well } \\
\text { (feet) }\end{array}$ & $\begin{array}{l}\text { Sample } \\
\text { code }\end{array}$ \\
\hline 26N/01E-10M01 & Qva & 97 & $1,2,3$ & $26 \mathrm{~N} / 01 \mathrm{E}-33 \mathrm{G} 01$ & Qva & 174 & $1,2,3,4$ \\
\hline 26N/01E-10N03 & Qva & 56 & $1,2,3$ & 26N/01E-34D01 & QC1pi & 168 & 1,2 \\
\hline $26 \mathrm{~N} / 01 \mathrm{E}-11 \mathrm{~L} 03$ & Qva & 95 & 1 & 26N/01E-34E01 & QC1pi & 99 & $1,2,3,4$ \\
\hline $26 \mathrm{~N} / 01 \mathrm{E}-12 \mathrm{C} 02$ & QC1pi & 150 & $1,2,3$ & $26 \mathrm{~N} / 01 \mathrm{E}-34 \mathrm{P} 02$ & $\mathrm{QC} 1$ & 209 & $1,2,3$ \\
\hline $26 \mathrm{~N} / 01 \mathrm{E}-13 \mathrm{~B} 01$ & QC1pi & 313 & 1 & $26 \mathrm{~N} / 01 \mathrm{E}-34 \mathrm{R} 01$ & QC1pi & 383 & 1 \\
\hline $26 \mathrm{~N} / 01 \mathrm{E}-13 \mathrm{C} 03$ & QC1pi & 265 & 1 & $26 \mathrm{~N} / 01 \mathrm{~W}-25 \mathrm{G} 03$ & Qva & 98 & $1,2,3,4$ \\
\hline $26 \mathrm{~N} / 01 \mathrm{E}-13 \mathrm{H} 04$ & Qva & 124 & $1,2,3$ & $26 \mathrm{~N} / 01 \mathrm{~W}-25 \mathrm{~L} 02$ & QA1 & 128 & $1,2,3,4$ \\
\hline $26 \mathrm{~N} / 01 \mathrm{E}-14 \mathrm{C} 01$ & QC1 & 323 & 1 & $26 \mathrm{~N} / 01 \mathrm{~W}-36 \mathrm{C} 01$ & QA1 & 165 & $1,2,3,4$ \\
\hline $26 \mathrm{~N} / 01 \mathrm{E}-14 \mathrm{R} 01$ & QC1 & 138 & 1 & 26N/01W-36J01 & QA1 & 197 & 1 \\
\hline $26 \mathrm{~N} / 01 \mathrm{E}-15 \mathrm{C} 02$ & Qva & 124 & $1,2,3,4$ & $26 \mathrm{~N} / 01 \mathrm{~W}-36 \mathrm{~J} 02$ & QC1 & 67 & $1,2,3,4$ \\
\hline $26 \mathrm{~N} / 01 \mathrm{E}-15 \mathrm{P} 02$ & Qva & 91 & $1,2,3$ & 26N/01W-36R02 & Qva & 43 & $1,2,3,4$ \\
\hline $26 \mathrm{~N} / 01 \mathrm{E}-16 \mathrm{D} 02$ & Qva & 126 & $1,2,3,4$ & $26 \mathrm{~N} / 01 \mathrm{~W}-36 \mathrm{R} 03$ & QA1 & 281 & 1 \\
\hline $26 \mathrm{~N} / 01 \mathrm{E}-16 \mathrm{~F} 03$ & Qva & 151 & 1 & 26N/02E-07E01 & QA1 & 365 & 1 \\
\hline $26 \mathrm{~N} / 01 \mathrm{E}-16 \mathrm{~N} 03$ & Qva & 177 & $1,2,3,4$ & 27N/01E-22Q04 & QC1pi & 95 & $1,2,3$ \\
\hline $26 \mathrm{~N} / 01 \mathrm{E}-17 \mathrm{C} 01$ & $\mathrm{QC} 1$ & 143.5 & 1,2 & $27 \mathrm{~N} / 01 \mathrm{E}-22 \mathrm{Q} 05$ & QA1 & 239 & 1,2 \\
\hline $26 \mathrm{~N} / 01 \mathrm{E}-18 \mathrm{P} 06$ & QA1 & 376 & 1,2 & 27N/01E-23M01 & QA1 & 302 & 1 \\
\hline $26 \mathrm{~N} / 01 \mathrm{E}-20 \mathrm{~J} 01$ & Qva & 226 & 1 & 27N/01E-26R01 & Qva & 97 & 1 \\
\hline $26 \mathrm{~N} / 01 \mathrm{E}-20 \mathrm{R} 01$ & Qva & 54 & 1,2 & 27N/01E-27J01 & Qva & 185 & 1,2 \\
\hline $26 \mathrm{~N} / 01 \mathrm{E}-21 \mathrm{E} 04$ & Qva & 60 & $1,2,3,4$ & 27N/01E-27J02 & QA1 & 466 & 1,2 \\
\hline $26 \mathrm{~N} / 01 \mathrm{E}-21 \mathrm{~N} 01$ & Qva & 210 & 1 & 27N/01E-27N01 & Qva & 134 & $1,2,3$ \\
\hline 26N/01E-22D02 & QA1 & 440 & 1 & $27 \mathrm{~N} / 01 \mathrm{E}-27 \mathrm{~N} 02$ & Qva & 95 & 1 \\
\hline 26N/01E-22M03 & Qva & 106 & $1,2,3,4$ & 27N/01E-28J02 & QA1 & 244 & 1 \\
\hline $26 \mathrm{~N} / 01 \mathrm{E}-22 \mathrm{~N} 03$ & Qva & 105 & 1,2 & 27N/01E-28K02 & QA1 & 150 & 1 \\
\hline $26 \mathrm{~N} / 01 \mathrm{E}-22 \mathrm{P} 01$ & QA1 & 175 & $1,2,3$ & $27 N / 01 E-33 B 02$ & $\mathrm{QC} 1$ & 138 & $1,2,3,4$ \\
\hline 26N/01E-26M02 & QC1pi & 64 & 1 & 27N/01E-33B03 & QA1 & 270 & 1 \\
\hline $26 \mathrm{~N} / 01 \mathrm{E}-28 \mathrm{D} 01$ & Qva & 183 & $1,2,3,4$ & $-33 \mathrm{~F} 02$ & Qva & 142 & 1 \\
\hline $26 \mathrm{~N} / 01 \mathrm{E}-28 \mathrm{E} 02$ & Qva & 217 & $1,2,3,4$ & $27 \mathrm{~N} / 01 \mathrm{E}-34 \mathrm{~K} 02$ & QC1 & 267 & 1 \\
\hline 26N/01E-28N02 & Qva & 188 & 1,2 & $27 \mathrm{~N} / 01 \mathrm{E}-35 \mathrm{C} 01$ & QC1 & 358 & 1,2 \\
\hline 26N/01E-30L01 & QC1pi & 331 & $1,2,3,4$ & $27 \mathrm{~N} / 01 \mathrm{E}-35 \mathrm{E} 01$ & $\mathrm{QC} 1$ & 205 & $1,2,3$ \\
\hline $26 \mathrm{~N} / 01 \mathrm{E}-32 \mathrm{E} 03$ & Qva & 82.5 & 1,2 & 27N/01E-35N01 & QC1pi & 326 & 1 \\
\hline $26 \mathrm{~N} / 01 \mathrm{E}-32 \mathrm{E} 05$ & Qvt & 48 & 1,2 & $27 \mathrm{~N} / 01 \mathrm{E}-36 \mathrm{~J} 03$ & Qva & 120 & 1 \\
\hline 26N/01E-32L05 & QA1 & 412 & $1,2,3,4$ & & & & \\
\hline 26N/01E-32M01 & Qva & 82 & 1,2 & & & & \\
\hline $26 \mathrm{~N} / 01 \mathrm{E}-33 \mathrm{~A} 02$ & Qva & 118 & 1,2 & & & & \\
\hline 26N/01E-33E01 & Qva & 159 & $1,2,3,4$ & & & & \\
\hline
\end{tabular}




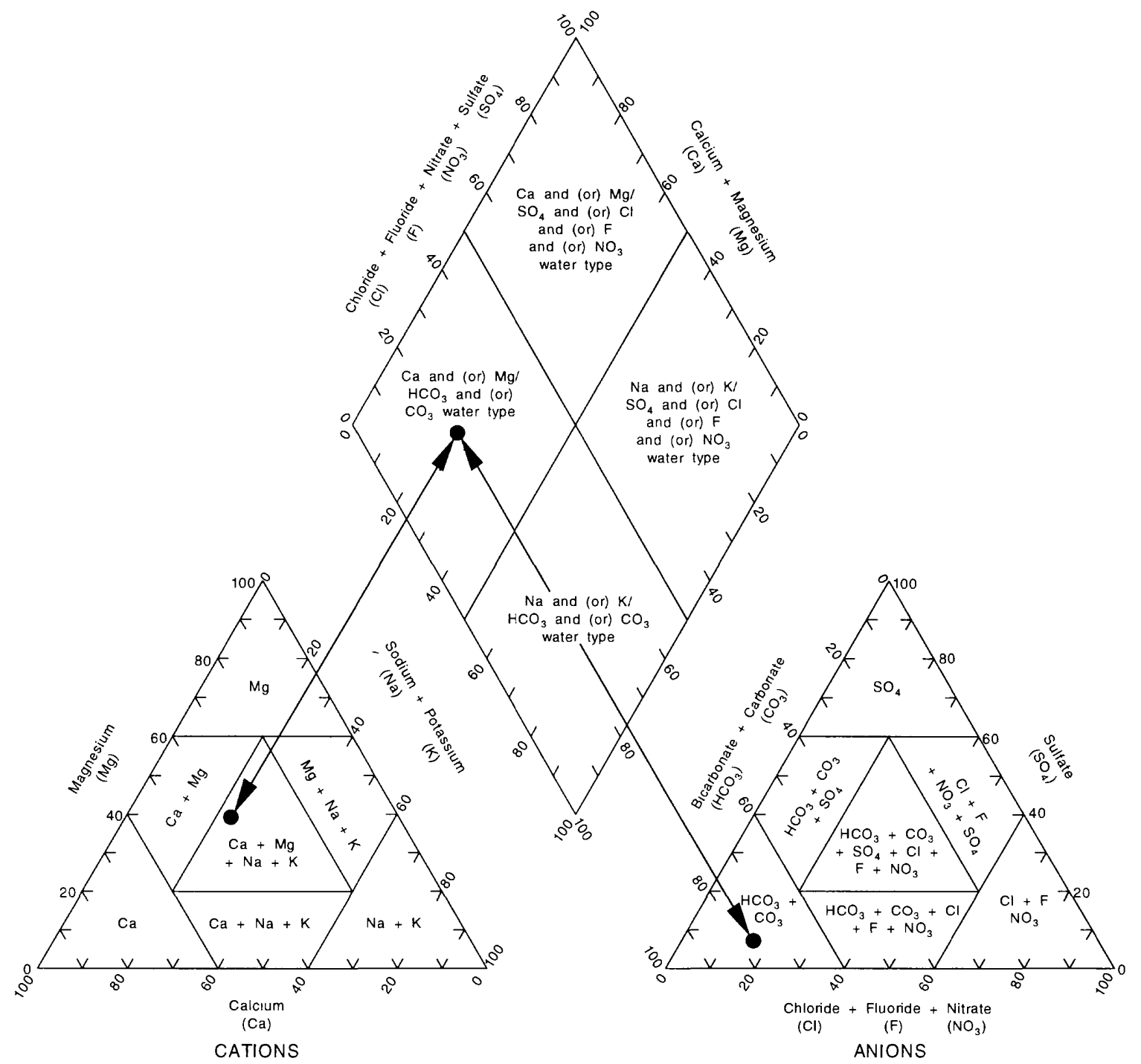

Appendix C. Example Piper diagram, showing water types represented in each area. Numbers are percentages. 